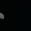



Digitized by the Internet Archive in 2007 with funding from Microsoft Corporation 


plour coopris sanst prea

of $\quad 57$, 
SPORTING AND MILITARY ADVENTURES. 

i's

, ...

1, , ,

$\because 3, \quad \cdots$

, , ?

?

$\therefore 3$

: 09

, 21,

i. ' $;$

$\because, 4,4$

, s. b. 


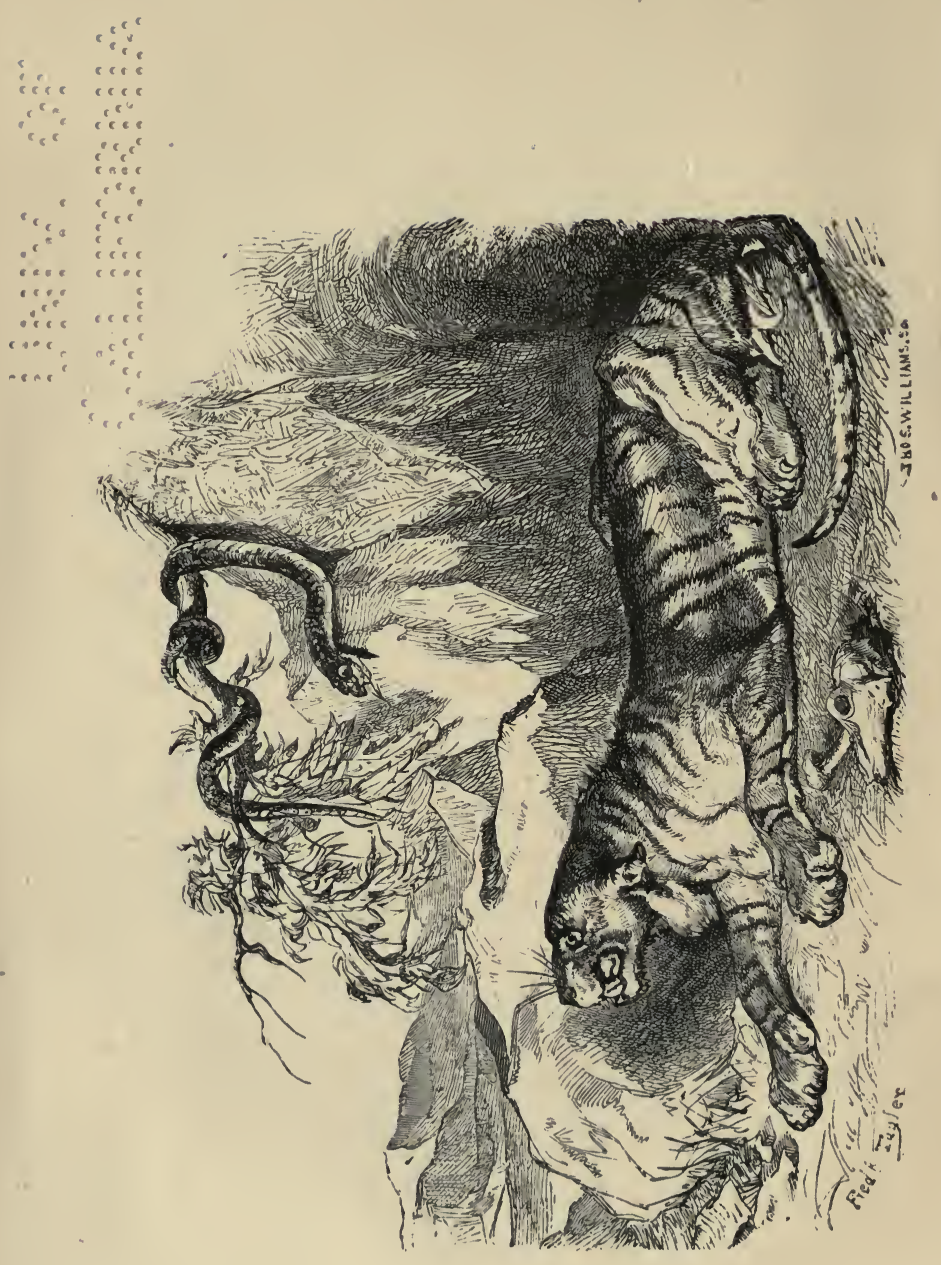




\section{SPORTING AND MILITARY}

\section{ADVENTURES}

IN NEPAUL AND THE HIMALAYAS.

A NARRATIVE OF PERSONAL ENCOUNTERS

AND NARROW ESCAPES,

BY

MAJOR BLAYNEY WALSHE.

\section{LONDON :}

JAMES BLACKIVOOD \& CO., LOVELL'S COURT, PATERNOSTER ROW. 
SK235 W25 


\section{PREFACE.}

IT requires but a few words of preface before launching my little volume on the sea of public opinion.

I know it will have to do battle with craft of a higher and more enduring nature, and may be utterly swamped in its endeavour to attain the goal of public approval; but I venture to hope it •will outlive the storms of criticism; and, if my readers have half the pleasure in the perusal of these pages that I have had in writing them, I shall be repaid.

Having passed some of the early years 
of my military career in India, I had opportunities of meeting with many adventures; and although a long period has elapsed since those days, a vivid recollection remains, of the campaigning and the sporting, that together, made up the pleasantest part of my life.

Breconshire,

October, I 875. 


\section{O N T E N T S.}

\section{CHAPTER I.}

Recollections of Early Life-Enter the Army-Quit England - Land at Calcutta-Pleasures during a short stay-On the March to Chinsura to join detachment-Arrival at the Mofussal, and account of the journey through-Near Chinsura-Nonarrival of baggage, and journey back to Calcutta in search of it -Meet with a few acquaintances-Return to Chinsura-Destination changed to Moorshedabad-A Skirmish with the Nepaulese and their defeat-First Encampment-Adventures of a Sporting Party

\section{CHAPTER II.}

Exciting Tale of an Adventure with a Tiger-Arrival of Despatches and Reinforcements-Again on the March-Another sharp engagement with the Nepaulese-Renewed Marching and description of the guides - Treaty with a Native Deserter-Falling in with the enemy, and renewed attack-Wounded - $\quad 5^{6}$

\section{CHAPTER III.}

A mysterious nurse-Kidnapped-In Prison-An unwelcome visitor-Escape and journey with a friendly guide-Narrow escape from a Cobra-Recaptured and condemned to deathA welcome letter-Released from Prison-Pursued - $\quad$ - 83

\section{CHAPTER IV.}

Weary hours passed with a mysterious deliverer-Sleeping in a tree-A breakfast of eggs and honey-News of the regiment -A guest of the Kotwál or Magistrate-Parting with a true friend-I.cave taking of the Kotwál-On the march in pursuit of the regiment 


\section{CHAPTER V.}

What occurred on the way-Hunting a miscreant Monkey and its consequences-Happy condition of my Horses and Servants-Entertained by a Juggling Party-Avoiding a snareFirst news and meeting with missing comrades-Recounting Adventures since our separation-Attacked with fever - $15^{8}$

\section{CHAPTER VI.}

On Leave for six months to the Himalayas-Idea of the Mountains, the Ascent-Arrival at Landour-ReflectionMeeting a cheerful companion Restored to health-Preparing for a shooting expedition-Encounter with a Black Bear, and result of first day's sport - Second day's sport - Narrow escape of a companion-Capture of a Black Boar - 200

\section{CHAPTER VII.}

Discussing the events of the day with the Shikari, and his startling acccount of an adventure with a Bengal Tiger-Third day's sport, and what we met with - - - - $\quad-235$

\section{CHAPTER VIII.}

Another interesting Tale of the Shikari's-Adventure with a musk elephant-Return to the hotel-Parting with the Shikari -Letter from the adjutant-Leave taking of a companion of the hills

\section{CHAPTER IX.}

On the road to rejoin head quartęrs - A hair-breadth escape - Capture of a monster alligator, and what was discovered in its maw-Meeting with old comrades-Another attack of fever-A grant of two year's leave on sick eertificate to return to England-A pleasant voyage and arrival home 303 


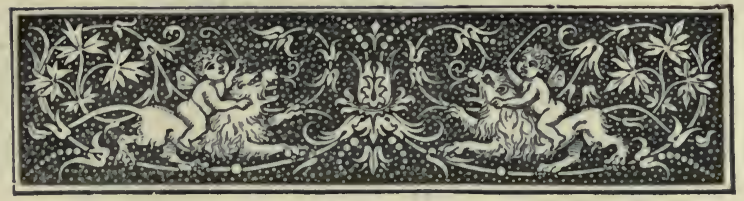

\section{SPORTING AND MILITARY}

\section{ADVENTURES.}

\section{CHAPTER I.}

Q WAS born in a small town on ?) (2) the west coast of Ireland, and though years have since rolled on, and I have passed through (a) many adventures in all climes, the \&) (.). (e) recollections of my much loved home have never been effaced from my mind. My rides on a shaggy pony, my first attempts at fishing, and the first successful capture of a trout, about the length of my 
little finger, are as vividly impressed on my heart as if it had all occurred yesterday. I can even recollect the conversations I had with the peasantry as I rode along, and can fancy I see the girls now, plodding into the neighbouring market with their poultry and eggs; some of them, in addition to their well-filled baskets, having to carry their shoes and stockings, ready to be replaced on their feet as they approached the town, whither their steps were bent.

I have been so long from my dear home that great changes have taken place, but not so many in the remote parts of Ireland as in other places. In the neighbourhood of which I am speaking, there is not even now a railroad within seventeen miles of our house, and there was then only a mountain road leading to it, which was so hilly and rough, that it half killed our poor 
old horse "Jack" whenever he traversed it, and each time we used to declare should be the last; notwithstanding our determination, the next time anything was wanted these resolves were forgotten, poor old "Jack" was pulled out of his comfortable stable and attached to our outside jaunting car, and off we would set to toil and crawl up the precipices, by courtesy called a road. Poor "Jack," as well as being old, was dreadfully fat, and it was pitiable to see him toiling up the steep hills; yet, notwithstanding his distress, we were cruel enough to urge him on both with voice and whip, for, if these adjuncts were not freely used, neither jaunting car nor Jack would have ever reached their destination, not to speak of the getting home again at night, when we would arrive half: dead and depressed, feeling thankful that 
the dreadful journey was over, and that we were safe at home again.

This sort of life lasted till I was sixteen years old, when it was decided upon, that I- was destined for the army; my uncle, who' was a general, applied to the authorities at the Horse Guards on my behalf, and I soon obtained a commission in the -th Regiment of foot. In due course I was ordered to join the depôt at Chatham; but I was not left long in peace there, for an order came from the Adjutant-General for a large draft to be prepared for India, and I was among one of the (as we then thought) unlucky ones included in the draft for immediate embarcation.

As the time drew nigh for sailing, my feelings underwent a complete change; instead of disliking the idea of going to the gorgeous East, I was enchanted at the 
prospect, and looked forward to the pigsticking, tiger-shooting and deer-stalking, with the greatest excitement and longing, counting the hours till we should embark. The time came at last, and I marched out of the garrison town with a much lighter heart than fellows usually do when starting for the East; and yet there are, perhaps, but few who reflect how possible it is that they may never return, but go on their way, never looking at anything gloomy, and thinking only of the bright future that awaits them. But, I am getting into a gloomy strain, which is not my object, as I think there are melancholy subjects enough in this world without mixing them up with our pleasant moments; and I intend that this little book shall show only as much of the gloomy side of life as necessary, and I shall try to confine my- 
self as much as possible to the amusing element.

We landed at Calcutta in due time, and soon found ourselves comfortably installed at a very fine hotel. Calcutta is justly named the "City of Palaces," and the hotels are certainly not behind hand in magnificence; our cuisine was excellent, the manager attentive, and after our boardship life our heads were in a fair way of being turned by all the attention we received. Balls and dinners, and every description of gaiety, gave us plenty to do, and the intense heat did not interfere with our enjoyment. However, we were not left to amuse ourselves long in Calcutta, before an orderly came to the commanding officer, who was staying at our hotel. I looked out of the window while Major $\mathrm{H} \longrightarrow$ was reading the order, 
and was struck with the novelty of the orderly's appearance. He was a private of the -th Bengal Light Cavalry, and mounted on a beautiful grey charger, which he sat with grace and dignity. His uniform was becoming, and at the same time, workman-like ; it consisted of a light blue jacket with orange facings, piped with white cord, looking at a distance like silver, which is worn by the officers of the corps, and, on a more intimate acquaintance with the regiment, I can dispassionately say there was not a finer corps in the service, or a more manly set of officers. To see them at a ball in their light blue and silver uniform, with their swords and spurs clanking, and their sabretashes striking against the broad silver lace down the outer seam of their overalls, was one of the prettiest sights possible; the girls 
seemed to like them as partners, and they usually selected the prettiest in the room, no belle requiring to be asked twice to dance with one of the dashing - th Bengal Light Cavalry.

I fear I have digressed while looking out at the smart mounted orderly on his capering and gaily caparisoned charger. I was roused from my reverie by Major $\mathrm{H}$ - calling to show me the route for us to march in the morning to Chinsura, which place is some twenty miles distant from Calcutta on the left bank of the river Hoogly. We marched the following morning at three o'clock, as it was the hot season, and the Major was anxious to get the recruits and soldiers into their tents at Chinsura before the sun became too hot, and the morning too advanced. Well, we got off pretty punctually, 
and, though we stumbled about a good deal in the dark while finding our various detachments, when we got to them, and marched them to their places in the main body, we were all safe; but, being unused to the darkness and the new life, I floundered about dreadfully, and, coming across a hackery bullock lying on my path, quietly munching his half digested breakfast, I of course stumbled over him; but he was so accustomed to affairs of that sort, that he continued his occupation as if nothing unusual had happened, leaving me to scramble up as best I could.

I then made a rush for my detachment, which I happily reached just before Major $\mathrm{H}$ — rode up to enquire why I had not moved it into column. I explained the cause, and then marched the men off to their appointed place. The column was 
called "to attention," and then came the words "quick march," when every man stepped off with the left foot to the enlivening tune of "The girl I left behind me." It is dreary work the first start in the early morn, and we plodded along in the dark, thinking of all the agreeable girls and kind friends we had quitted; and I was brooding over my uncertain prospects, with other matters not of a cheering or exhilarating nature, when I was roused from my reflections by the "halt." After an hour's marching in India there is always a halt for ten minutes, and this has a capital effect, as it allows the men time to re-settle their knapsacks, or take a boot off, making them more prepared to encounter the fatigues of the next three and a half miles, this distance being about the usual pace at which soldiers march. We now lighted 
our pipes and cheroots, which every one smoked in my time; a man might have gone in those days from the Himalaya Mountains to the most southern point of Ceylon without seeing a cigar.

The command to march was given, and we were soon well out of the suburbs of Calcutta, and had reached what the AngloIndians call the "Mofussal," which means the country lying outside the town and suburbs of Calcutta. It was now broad daylight, for, in all tropical climes the transition from darkness to light is very rapid; indeed, I often afterwards found that, almost while mounting my horse and riding quietly out of my compound, the transition had taken place.

We now got into the pretty market and flower gardens surrounding Calcutta, where the beauty of the flowers and the 
sweetness of their perfume defy description. The road was now superb, and we stepped along like heroes, and at the next halt we were refreshed with hot coffee, which had been sent on by a trusty servant the previous evening; it was all ready for us, and each officer had a steaming cup of that reviving beverage, especially so at that early hour in the morning. Coffee should be called the morning elixir of life, as we call champagne, or sparkling moselle, the night elixir. The word of command to march was given for the third time, and off we stepped again to the tune of "We're all noddin." By this time we, the officers, formed into little sets, confined to our own particular chums; and, as the men were marching "at ease," the commanding officer did not care how we got along, provided we 
were sufficiently near to fall in should it be requisite; but in a friendly country, and within a few miles of our own capital, and in the midst of our own dominions, there was little chance of a surprise, though I found out afterwards, to my great discomfort, that too much confidence cannot be placed in appearances;-but more of this anon.

We were now within a kos of Chinsura (I should explain that a kos is two English miles) when we heard the continual beating of the tam-tam,announcing to the tired and foot-worn soldiers that the tents of the camp were in sight, to the great joy of the men, many of whom were not in an enviable state from having imbibed too much arrack the previous evening in company with some warrior who could sleep off the effects of the drowsy god, instead of 
having to take a weary march of twenty miles through deep dust, and frequently heavy sand; the poor sufferer groaning in spirit, and making many good resolutions, which are strictly carried out until he meets a convivial friend the next night, when the same farce is enacted again with the same results. It appears to me that soldiers are the most thoughtless people on the face of the earth; I have often studied their character, and must confess that I am completely puzzled. They are kind, liberal, and generous to a degree; but, on the other hand, they are the most improvident creatures in the world, and I believe they would persist in drinking a glass of brandy if they were assured they would be dead an hour after it. This recklessness kills many of our brave fellows, and indeed, if it were not for this 
dreadful infatuation, we should not find them so easy to obtain. I shall now go on with my story, and cast moralising to the winds.

We had hardly started on our march this morning when I discovered that no hackery had come for my tent and baggage, so I lost no time, when the men were dismissed, in waiting on Major $\mathrm{H}-$ and asking permission to be allowed to ride back and see after my belongings; this he immediately assented to, and a few minutes saw me off, mounted on a wiry, but miserably ugly tattú, or native bred pony: they are very generally used throughout the Bengal Presidency by officers, to carry them out to parades, luncheons, or tiffins, -as we Anglo Indians call them; and, in fact, wherever quickness and durability are required. They are wonderfully enduring, 
but are of comparatively little value, as you can,--or could at the time of which I am writing-procure one of these useful little animals for fifty rupees, (five pounds of our English money) and they will do the work of a horse ten times their value. I have often thought how useful they would be in this country if they could be brought home in sufficient numbers to pay. I fancy if a good many of them were shipped from Calcutta they might be sold in England at eight or ten pounds a head, and they would not cost more than a pound or thirty shillings each for the passage. It is a pity some speculative individual does not try it, as I believe it would be a certain profit.

I cantered back to Calcutta in less than two hours, and found my tent still standing and my servants calmly sleeping in the shade as comfortably and con- 
tentedly as if the tent had been transported and erected in its proper place in our camp at Chinsura. I rushed at the man whose business it was to take the tent down; and, angry as I then was, I need not say that he did not awake to find a bed of roses; his shrieks soon brought all my naukar $\log$ (servants) around us, and then such a Babel of sounds penetrated my ears that I was stupified at first; each man wished me clearly to understand it was not his fault, but that the delay was all owing to the idleness and wickedness of all the others; and that I was a Rustumjee,-which means a good master,-and my clear good sense would soon shew me who was my faithful servant, and who were Shaitans, or sons of the devil. This row continued till I lost all patience, and I used my chàbuk, or whip, with vigour and satisfactory re- 
sults, for, in ten minutes I had them all at work taking the tent down and carefully packing it up. This took the best part of an hour; I need not say I was a happy man when I saw it, at last, safely packed, and in the hackery with my other belongings, and the bullocks moving off with the creaking and screaming vehicle; the driver screwing at the poor animals tails as if he were moving the ponderous machine entirely by his own labours.

I now began to feel hungry, and, recollecting I had not taken anything to eat since my dinner at our mess on the previous evening, I directed my steps towards my old hotel, after I had seen my tattú carefully attended to. The poor pony had done some hard work already. All officers' horses and ponies are led in the rear of the regiment on the line of march, and 
any officer who wishes to ride when the men are marching at ease, has only to fall out and let the regiment go on, and when his horse comes up he can mount him. When the "tap" on the big drum calls to march "at attention," he may dismount and run up to take his place in the column, drawing his sword, and falling in. In this way my tattu had done the march to Chinsura; I had afterwards cantered him back to Calcutta, and in the cool of the evening I had made up my mind to ride him back again to Chinsura, that I might be in time to march with our detachment the next morning. Few horses could be got to do so much work, and I suppose, the native ponies being so cheap, one does not care so much about injuring them by making them go when required to do so. After a very good luncheon at the hotel 
and a bottle of "fizz," I strolled about, looking up my military friends; for, short though my stay had been in Calcutta, I had formed many friendships. On looking back I am astonished at the facility with which I made acquaintances, and even intimate friends, in those days, compared with the difficulty I have now in doing the same. After paying a few visits, I ordered the unhappy pony to be again saddled, and it was nice and cool when I started; he took me back with the greatest ease in two hours and a half, just in time for a late dinner at the mess, to the astonishment of all the detachment. Next morning the taps went at five o'clock, and we marched off much as we had done yesterday, barring the tumble over the bullock, which, happily, I avoided, as I suppose I kept a sharper look out. At the 
first halt Major $\mathrm{H}$ informed us our destination was changed from Moorshedabad to Alleighur, in consequence of disturbances in the Nepaul country. He was under the impression that we should be engaged with the Nepaulese in the course of a few days, from the rumours we had heard in the bazaar; and news finds its way into the bazaar frequently many days before the Government despatches reach the officer commanding the troops in the field.

The rumour in this case was, that the Nepaulese were in great force in a strong position among the mountains, near the entrance into their country. Of course we were enchanted at this news, for we were all tired of the monotony of the march, or, at any rate, we knew we should be before it had lasted much longer. When 
we arrived at our camp, all uncertainty was at an end, for an official order was awaiting the commanding officer, directing him to hold the troops under his command in readiness for immediate service in the field, and desiring him to halt where he was for a few days to allow detachments, which were on their way to join him, to arrive. There was a field battery of artillery to join us, and we also required an officer to take charge of the commissariat, as we should soon be in an enemy's country, where it would be impossible to procure even a goat, or a loaf of bread; therefore it was incumbent on us to be fully prepared in every respect with abundance of provisions, and also an unlimited supply of ammunition to subdue our swarthy enemies, who had the reputation of being extremely handy with their 
talwárs (swords). They have, also, a very unpleasant weapon called a jeel, which they throw with great precision and dexterity; it is in the form of a quoit, only larger, and sharp at the edges; this is rapidly revolved on the fore finger till it has attained a certain velocity, when, with a sudden jerk, they can propel it in any direction they wish. It goes like an arrow, and woe betide the unfortunate individual it strikes; if it hits him full on the chest it will cut him in half, or maim him so dreadfully that the chances are he would never recover, or, if he did, he would be a burden to himself and his friends for life.

As may be supposed the news of the coming campaign elated the old soldiers of the detachment vastly, and the recruits vied with their more experienced brethren 
in enthusiasm and determination. I was much surprised at the manly pride our recruits displayed when they found they were really in for hard fighting; they seemed as joyous as boys released from school, and nothing but sounds of exhilarating fun and laughter were heard all over the camp. Next morning, long before daylight, we silently fell in; and, when the word "quick march" was given, I felt a tremor run through my frame that was quite unaccountable to me at the time, but I have since learned it was simply a bracing of the nervous system, which I believe most men experience when starting on a perilous and highly exciting undertaking.

We started silently, without even a bugle sound, and the drums and fifes were likewise silent, so we must have resembled 
ghosts gliding through the black gloom of the early morning. We took every precaution, and had advance and rear guards, and also picquets on either flank, and, indeed, carried out the regulations for the advance of troops in an enemy's country to the very letter : lucky it was that we did so, for we had hardly advanced ten miles when one of the scouts came running in with the astounding information that a very large army was drawn up across our road, and it must be dislodged before we could proceed. Major $\mathrm{H} \longrightarrow$ did not hesitate long, but formed us up in the order in which he meant we should fight. He threw out strong flanking parties, and led the attack himself with the main body, leaving a strong reserve, or support, under my command; he also left a very shrewd colorsergeant with me to advise me; this ser- 
geant was, in fact, my commandant for the time being.

Our attention was soon occupied with what was going on in front, for our gallant comrades were now in the thick of it; they. advanced in splendid style, without firing a shot in reply to the showers of arrows, jeels, and quoits, which came in dense masses on our brave little army. We were filled with pride and admiration at the determined and steady advance which they maintained under such a murderous volley of deadly missiles. By this time they were close up to the main body of the Nepaulese, and then the order was given to form line, which order I thought should have been given before. This formation did not take more than a few minutes to execute, as it was done at the double; and then we poured such a withering fire into 
them that they turned and fled in all directions, our guns pouring in grape shot and shells among them whenever a few congregated anywhere within range. In ten minutes from the time our attacking party started not a Nepaulese was to be seen near us, and in another half-hour not one was in sight. I had the greatest difficulty in restraining my command, which, I need not say, was chiefly composed of recruits, with a few recovered men among them, who were too weak for the exertion of climbing the hills and fighting at the same time; besides, it would not have been prudent to have left me nothing but recruits.

We pursued the ememy for several miles, and my little army being fresh and vigorous, having just landed in India, shewed their British pluck and activity by chasing them like hounds, or, I should 
say, coursing them like greyhounds. It was nearly dark before we got all the pursuers back; then the men fell in to answer to their names, and I am happy to say our loss was comparatively small, considering how sharp the affair had been while it lasted. We found out afterwards from prisoners, and other sources, that the enemy was completely taken by surprise; they thought our commanding officer would have been taken aback and would not know what to do, and they intended, when all was in confusion in our army (as they had calculated it would be), to rush down on us and gain an easy victory. But Major $\mathrm{H} \longrightarrow$ had been equal to the occasion, and hence we had gained a most complete and overwhelming victory.

Our joy is not to be described, and officers and men were equally pleased at 
their morning's work. There was one dreadful drawback, however, which we for a time lost sight of, and this was the loss of so many dear and valued comrades with whom we had been associating daily for months, now swept out of our sight without a moment's preparation or warning. It seems strange that soldiers, who are living from day to day with their lives in their hands, should be, as a rule, the most thoughtless and careless regarding their eternal salvation.

Some of the wounds were very bad cases, the quoits having inflicted fearful injuries; one man was nearly cut in two, and, strange to say, he lingered for hours till death happily released him from his dreadful sufferings. I shall not dwell on this subject only to mention one case of a private who I heard was lying dangerously 
wounded in hospital. He had been my servant, and without delay I went to see him. I found him in bed, sitting up every few minutes and then tumbling back. He had a fearful wound in the head, and the brain protruded considerably; he lived in this state for hours. I only mention this case to show the vitality there is in the human frame; I was under the impression that any injury to the brain was instant death.

Major $\mathrm{H} \longrightarrow$ determined to halt where he was, and to send off a dispatch announcing our complete victory, at the same time asking for instructions. He strengthened our position as much as possible, by cutting down trees and throwing up earth-works; posted strong picquets on the adjoining hills; and, in fact, did all that an able commander could 
do for the protection of his little army. All this gave us ample occupation for the next few days ; and then, as it would take weeks before we could hear from the Commander in Chief, and as we were assured from the accounts of the villagers, who brought milk, eggs, ghi (a kind of butter), and poultry into our camp daily, that there were no hostile Nepaulese in our neighbourhood, some of us youngsters determined to try the shooting in the vicinity of our encampment; for we heard there were plenty of bison, deer, jungle fowl and pea fowl, besides partridge, quail, and hare.

One morning, just as the sun was rising in Oriental splendour, four of us sallied out with our guns, intent on making a good bag. We had asked the Major's permission to go, and he had insisted upon 
our taking half-a-dozen soldiers with us as beaters; as they would have their muskets, he thought, in case we came across any hostile Nepaulese, and twelve of us could make a good running fight back to camp. He insisted also upon our observing the strictest caution and prudence, and then kindly wished us good sport. When it was known that we required half-a-dozen volunteers to accompany us, the whole detachment said they were ready, and we had much difficulty in making them understand that we would only take six. We allowed them to select the required number themselves, it was done, after a great deal of discussion, as all wished to come, and the lucky ones were told to be ready to accompany us at sunrise the next morning. On issuing from our tents we found them ready, with their muskets and pouch belts filled 
with ball cartridge, and so we started at once, and made for a thickly wooded valley which lay to the right of our camp. We had not proceeded two hundred yards through the thick jungle when I heard a tremendous noise of rustling, as if a large animal was disturbed, and passing through the thick underwood; this was on my right front. I immediately cried out, "Mark!" when a huge bull buffalo darted into an open spot of burnt jungle, and crossed it rapidly. We all blazed away, when, to our intense amazement and disgust, he went off, apparently untouched. We looked at each other in mute astonishment, till at last, M- who was one of our party, proposed we should return home, as he did not think we should have an opportunity of trying at anything larger! After a short consultation we all decided 
that we had fired in a hurry, and determined to be very cool and aim more carefully before pulling the triggers next time. We then reformed line, and proceeded, hoping for better luck: it mortified me greatly to see a broad grin on the faces of our military attendants, but I trusted that my next shot would make amends for the last one.

We had not proceeded far before a. noble black buck sprang to his feet, and, unluckily for him, stopped for a second to reconnoitre, when I seized the opportunity and planted a bullet exactly between his eyes, which brought him down with a crash, to the great delight of my brother sportsmen, and to the surprise of our escort, who begun to see we were not such muffs as they thought us. My successful shot gave us fresh confidence, and from 
that time we shot very fairly, making a much better bag than I had anticipated. We had to leave all our game, excepting the jungle-fowl and the partridge; and as we proceeded, found we had bagged quite as many as our escort could carry, considering they had, in addition, their muskets and thirty rounds of ball cartridge in their pouches. We had each our bearers, but they carried our ammunition and whatever drink their master fancied: some had brandy, some claret, and I, for one, had cold tea, in a bottle, without either milk or sugar; and though I was a griff in those days, I have still adhered to this practise, and after some thirty years experience think it much the most refreshing beverage. It invigorates you sufficiently, without spoiling your shooting, 
which brandy and water, or wine, always does for me.

We returned in time for mess at seven o'clock, and great was the curiosity to hear what was the amount of our bag, and what we had seen, and whether we had met any hostile Nepaulese. Major $\mathrm{H}$ - was equally anxious to know what the country was like; whether there were any roads, and if it would be easy for an army to ght through it: answering all these questions as well as we could, we hastened to dress for mess, which we did in an incredibly short space of time, getting in before the soup was removed.

We underwent great chaffing at our missing the bull bison, but the bag we brought home, and the quantity of large game left behind (which could not bc 
brought in till the next morning) made them look upon us as sportsmen entitled to some respect. As the dinner progressed, conversation became more general, and we soon were in harmony with each other. The Artillery officers, of whom I spoke before as joining our detachment, had made their appearance at our mess for the first time, and proved, as the Artillery officers always do, a great acquisition to our party. The Captain in command of them had been many years in India and was a great sportsman; so when the cloth was removed, and we were enjoying our wine, one of his officers asked him to relate the adventure he once had with a tiger in the Rajmahal Hills; this he consented to do, and filling his glass, commenced :

"You must all know that twenty years 
ago tigers were much more frequently seen and were fiercer than they are now, and there was then no reward of fifty rupees for killing one. The shikari (native sportsman) in those days were only armed with a spear, which perhaps is formidable enough to attack a wild hog, but no man in his senses would think of attacking a man-eating tiger with a spear, and they were then nearly all man-eaters. I liked the excitement of having a pitched battle with those cruel brutes, and often have spent the night in a tree adjoining large jungles where they abound, and which commandea the path they usually travelled. By constant practice, and always handling my rifle, I became a clipping shot; and let me take this opportunity of warning any of my young friends present not to think of going out tiger shooting 
unless he knows he is thoroughly master of his weapon, and has implicit confidence in his firmness. Being a good shot gives a man great pluck, which is highly necessary in tiger shooting.

"Well, I was sent off in charge of a small detachment with two guns into the Rajmahal district, and tired enough I became of my own society, for I had not a soul to speak to, nor a white face within miles, my party being all native gunners. One evening I was sitting on a chair, with my legs up on another, in front of my tent, smoking a cheroot and moistening my lips with brandy and soda water, wondering how I should get through the next twenty days of the march, when I heard a beating of tam-tams (native drums) and great chattering and yelling of the natives near a village about half a kos off, but I 
took no notice of it for some time, till I saw a large party of them making for my camp. They were headed by an old man who turned out to be the Kotwl of the village. This Kotwl (or, native magistrate) came to tell me that his only daughter, Nema, had been out for a walk that afternoon near the village, with a friend, when suddenly, a tiger sprang out of a bush after they had passed it, and seized the unfortunate Nema, carrying her off to the jungle. Her friend raised such an outcry that the distracted father and several of his men were in time to see the tiger cutting off in the distance, and the poor girl being dragged along the ground; they followed with tam-tams, yelling, and making all sorts of noises, but it had only the effect of sending the tiger and his prey further into the jungle. They 
had now come to beg of me to shoot the brute for them, as this was the sixth victim that had been taken by this dreadful maneater. It is a singular fact that if a tiger has once eaten a human being he does not care for any other food:

"The villagers told my servants that Nema was a lovely girl, beloved by all who knew her for her sweetness of disposition, and her charity and kindness to the poor. I could not but feel interested in so sad an affair, and, though it wanted only an hour to sunset, I told the bereaved father that I would accompany him at once; so, shouldering my double-barrelled rifle, and with plenty of powder and ball, carried by a servant on whom I could depend, I started, and we soon came to the village where the catastrophe had occurred. I was taken to 
the bush, and there saw the marks of the poor girl being dragged, which marks we followed until we came to the jungle from whence they had driven the man-eater; here the jungle was much more dense, and I had great difficulty in forcing myself through it: I had to exercise the greatest caution, for the tiger might spring on me any moment without the slightest warning.

"We had not proceeded a quarter of a mile when we heard a dreadful roar, which sounded as if it came from just under our feet. This was enough to send the whole of the natives to the right about, and they scuttled off like men; to make matters worse, with them went my native servant who had often been out with me, carrying a spare gun and the ammunition, and he had always stuck to me well until this oc- 
casion; so I found myself with only two barrels in the immediate presence of this noted man-eater. I knew if I turned tail, which I had every inclination to do, I could not have gone two yards before he would have been upon me, so my only chance was to show a bold front, and I firmly believe that was the only thing that saved me. I stared hard at where the horrid roars came from, with both barrels cocked, and my finger on the trigger, but all was still as death, and I fancied I heard my heart beating; this silence seemed interminable, and I felt I must go mad if it lasted much longer. In a few seconds I saw the tall reeds quiver slightly in a hollow just in front of me, and I need not say that I gazed on them as if my life depended upon it, which it certainly did, for in another second I spied my mortal enemy 
quietly gliding through the reeds. In a moment my rifle was to my shoulder, and after a steady aim I pulled the trigger, but, to my horror, no explosion followed. I immediately aimed at him with the second barrel, but I suppose I was too flurried by the first barrel missing, for I missed the vital part I aimed at, and only wounded him. He turned at once, and with an unearthly roar, which I seem to hear still ringing in my ears, I found myself on my back in a moment, and the tiger quietly contemplating me.

"I now felt my last hour was come, and coinmended myself to the mercy of the Almighty. At this instant the tiger threw up his head and looked the way by which we had come; hope began to fill my breast, as I knew assistance was at hand; indeed, I heard the sound of approaching 
footsteps-when, in a second, the tiger caught me up in his mouth by the arm, and, with a dexterous toss of the head, jerked my body over his back, and quietly trotted off into the darkest and most dense part of the jungle. I suffered the most excruciating pain from my arm, which was in some way twisted back. I gave myself more than ever up for-lost, and only prayed that the end would be speedy. "Suddenly I recollected that I had a small double-barrelled pistol in my belt, which I, with great difficulty, disengaged and managed to cock. Just at this moment the brute stopped to listen, and, after feeling quietly for the beating of his heart, I put the muzzle of the pistol to the spot and fired, when, to my inexpressible delight the tiger's jaws relaxed, and he dropped gently on his face and lay 
motionless. I have no recollection of anything after this till I found myself in a doli, or native palanquin, being carried along on the line of march. . It appears I was insensible for three days, and then a raging fever took possession of me. Fortunately we were near a station where there was a civil surgeon, and I was carried to his bungalow; by his skill and God's goodness my life was spared, and I am now able to relate this adventure, and also to enjoy a very agreeable evening in your society."

We young sportsmen listened to this exciting story with breathless attention, and did not rouse ourselves until the Captain had risen and wished us good night. We sat for a long time talking over the pros and cons of the war, and whether it was likely to last or not, my impression 
being that the natives were raising an army, and that we should have very sharp fighting before we returned to our cantonments; and, as the sequel will show, I was not far wrong. 


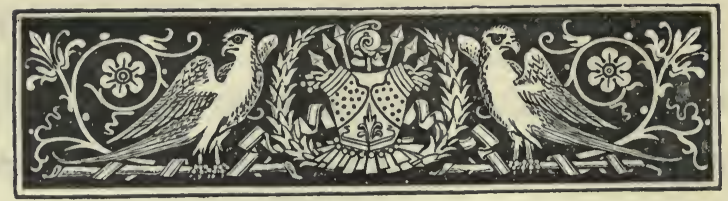

\section{CHAPTER II.}

(6) HREE weeks passed before we had any dispatch from the military authorities, in the mean time my sporting friends and myself kept the camp well supplied with game; we bagged large game very often, and at our mess we revelled also in partridge pies, jugged and roast hares, and occasionally a florakin, which is reckoned the finest flavoured bird in India. It is about the size of a jungle cock, but its flesh is very tender and delicate, and it was greatly esteemed by 
the "bon vivans" in our camp. I don't know what we should have done with ourselves had it not been for our shooting, for the mere detail of mounting main guard, and seeing after the outlying picquets was most monotonous work. We were also cut off from all intercourse with the outer world so thoroughly, that we hardly ever received a letter; indeed, till the commander in chief's dispatch came in, we had not received a single chit (as we call letters in India) since entering the enemy's country.

The arrival of this dispatch, and our private letters with it, diffused general joy throughout the camp; and everyone from from being dull and discontented suddenly became alert and joyous. This was greatly caused by the orders we had received. The war was to be prosecuted 
with the utmost vigour, and a large column of troops were then en route for us, under the command of a well-known and popular general. The military authorities were very much pleased with the way in which Major $\mathrm{H}-$ and his small force had behaved, and we all saw that he and his little army had plenty of work cut out for them before the campaign was over. It was this that so delighted us, for, in a climate like India, one must have constant excitement, and what excitement to a soldier is equal to a short and brisk campaign?

We did not expect the reinforcements to join us for another fortnight, and all our time off picquet duty and guard was devoted to drilling and being drilled. A great part of our force was recruits; some of them had a little drill at Chatham 
before embarking, but some had been put on board ship as soon as they had got their uniform, there being no time to drill them; so we were now making up for lost time, and I must say, I never saw any young men improve so rapidly as our recruits did. They saw the necessity for learning their work, as they were all anxious to be enrolled in a battalion with the older soldiers, and they also wished to take a more active part in the next engagement than they did in the last.

About ten days after the receipt of the dispatch, one afternoon we saw a quantity of dust ascending, a sure sign that troops are in motion; on examination, this dust appeared to be approaching, though still a long way off, but after a little we discovered, by the length of it, that it was a column of troops in motion. We 
all mounted our horses and tattus and hurried out to meet them, which we did after a good gallop of three or four miles. They were, as we expected, the reinforcements for us, and we were delighted with the appearance of the stalwart veterans composing the force sent out to assist us: we youngsters were charmed at the way these tried soldiers stepped out, and the firm determination they displayed in putting their feet to the ground in marching. The reinforcement consisted of two battalions of infantry, a troop of horse artillery, and a few mountain guns carried on strong mules, and I may now say that we found them most useful. If a body of the enemy had assembled in any difficult piece of jungle which the horse artillery could not penetrate, a couple of mules could easily be led near the spot, and the 
little mountain guns soon put in position; thus, when the enemy thought our guns were miles in rear, they were bewildered at finding a couple of shells bursting in the midst of them, and knocking perhaps half a dozen of them over before they had time to escape. We often managed this at the beginning of the campaign, but after a little they became too cunning, and carefully avoided us if our party consisted of more than half a dozen.

But to return to my story. We allowed the troops two days rest to get their arms and accoutrements put in order, and rubbed up; besides, the horses and mules required rest and shoeing, and the pack saddles restuffing.

On the third morning the whole force started off, leaving only a sergeant's guard to take care of the camp, and such 
of the chattels we did not require to take with us. We took the precaution to build a rough, strong fort into which the soldiers could retire in the event of an enemy attacking them; which, however, we thought highly improbable.

Some spies had come into our camp and told our commanding officer that the enemy were collecting in masses on the opposite bank of a small river about fifty kos from us; they said that men were joining them in great numbers, and they had already a very formidable army. I think it was this news that hurried our commander, for he knew that the longer he left them in peace the larger the army he would have opposed to him.

The first few miles were through a pretty, undulating country, with sufficient jungle to give it the appearance of a 
gentleman's park, but afterwards we got into the mountains, and then our serious troubles began: frequently the bushes and trees were so thick that it took the pioneers hours to cut a very short distance, indeed, sometimes it took some hours to advance a hundred yards. The Horse Artillery retarded us very much, as we required quite a road for them, but we knew we should derive ample benefit from them when we came to close quarters with the enemy; at the rate we were progressing we should not be in their vicinity for weeks, and if the rains came on it might be months before we came into collision with them. Our policy was to make an attack with as little delay as possible, but these dreadful, dense jungles served their friends in good stead. I often thought that if they had attacked us in 
some of the ugly places we had to pass through, though we had taken every precaution in our power, they might have inflicted great loss on us: in some places they could have concealed themselves so effectually, and still have had us under control, that they might have decimated us without our being able even to see them.

By gradually advancing every day, and working pretty nearly day and night, we at last approached the enemy's camp, which we decided upon storming the next morning at daylight.

In fighting with natives of India it is a fatal mistake to allow any time to elapse before attacking them; they attribute all delay to fear, and the more you procrastinate, the more their courage rises. However, in this case, we did not leave 
much time for them to lay in a stock of courage at our expense, for we were in their entrenched camp before breakfast time the following morning. The storming party had been prepared over night and I was glad to find myself one of them. We knew where to assemble before daylight, so, when all was ready, we moved forward to our appointed places near the stockade. Shortly after this, just at daylight, the Horse Artillery galloped to the front and unlimbered; and, in a quarter of an hour, they had opened a breach in the wall of the stockade. There the command was given for us to rush through the breach at "the double." With a loud cheer we pressed forward, getting over the intervening space in a few seconds, and rushed into the breach, when the day's work began. We found 
there was an inner stockade, of which we had no idea; and, though we soon dispersed the strong body of the enemy defending the entrance into the breach, they, after being forced back, retreated, leaving about fifty dead and wounded in our possession. They retired into the inner stockade which was securely barricaded, and then we found ourselves perfectly helpless to do anything more: we had no guns with us, and the Horse Artillery had retired; we had no scaling ladders, and there we stood to be shot at like crows, and many a poor fellow was shot down through the loopholes of the second wall.

I should here mention that the officer commanding the storming party was killed at the outer breach, and I do not know what would have become of us if 
Major $\mathrm{H} \_$had not galloped in among us and ordered an instant retreat; none of us subalterns would have dreamed of giving such an order, but we saw nothing more could be done, and it would have been something very like murder to keep us any longer there, nothing being prepared for either scaling or breaching the wall.

It can be well imagined how despairing and sad we felt at having to retrace our steps and retreat from a stockade which we fancied we had nobly won; but, contenting ourselves with the thought that it was the fortune of war, we hoped to be more successful another time. Our loss was great, and, unfortunately, we could not spare any of our men, so far as we were from our base. Our retreat was not followed, and we were able to carry off our dead 
and wounded. We were again formed up, and the artillery, with great difficulty, mounted two guns, which commanded the inside stockade; they soon opened fire, and in a shor time a breach was made, which enabled a fresh storming party to enter; and in a few more minutes the place was ours. After the artillery had opened the breach they turned their attention to sending two live shells into the stockade, and when our storming party entered it, they found themselves surrounded by dead bodies, the deadly work of our shells. The enemy being so numerous, and the space so confined, they could not get out of the way of the quantity of shells that dropped in; the artillery practice was very good, each shell, when it burst, killing some half-dozen men, and their loss was therefore very great. 
I had a narrow escape in the first assault. Just as I was about to enter the fort, or stockade, a warrior met me, armed with a long, heavy spear; I had only my little regimental sword, with which I tried to cut the thick wooden handle of the spear; but, instead of cutting it, the blade shivered in pieces, leaving the handle still in my hand. The spearman surveyed my loss with a grim smile and renewed the attack with fresh impetus; I was quite at his mercy, when one of the privates fortunately came up, most opportunely for me; he lost no time in passing his bayonet through my antagonist, and thus saved my life. I was in the act of expressing my gratitude to the gallant fellow when a quoit came spinning through the air, absolutely cutting the top of his head clean off, to my great horror and surprise; the poor fellow kept 
his legs and his position for a few seconds, and then tumbled heavily on his face. I stooped down and slightly raised him, but saw at a glance he was quite dead; and, as our work was only beginning, I could not remain longer with him.

We inflicted such a loss on the enemy that in the morning there was not one in sight; but we found a large number of native bullocks, which we were very glad to get, as we had for several days been in want of fresh provisions, and now we had abundance.

We returned to our camp thoroughly worn out and exhausted, and, if ever men slept well, we did that night. Every day for nearly a month we had been hard at work from daylight, frequently till hours after dark, for we would only halt where there was a supply of water; this was 
not always procurable, and we had often to go long distances out of our way for it.

I rose early the next morning and proceeded to the mess tent to enquire "What's the news?" But, though I asked many of my brother officers whom I met, no one seemed to know what would be the next move. I felt sure, in my own mind, that Government would not send so large a force such a distance without inflicting a lesson that the natives would not easily forget, and subsequent events showed I was not far out in my surmises. About mid-day I heard that we were to follow the Nepaulese army as soon as the men and horses were sufficiently rested, and, as this would entail the delay of a week, I determined to have a little shooting; so, one day I started with two 
brother officers, and we had wonderful sport.

In addition to deer, bison, pea and jungle fowl, and florakin, we came across the jakoor, or Himalaya pheasant, but we were unable to bag any of these; however, I made up for it afterwards by shooting a wild sheep, which was a source of great pleasure to us, as it was the first we had met with, and we had frequently wondered at not coming across any. The éclat of this exploit fell to me, and I was heartily congratulated on my success when I returned to camp in the evening.

A very few days saw us en route once more after the Nepaulese, who we heard had established their head-quarters on the top of an almost inaccessible mountain about twenty days' march from where we were; and the rumours about 
the country we must pass through, and the dense jungles we should have to penetrate, almost made one's hair stand on end. However, we started at sunrise the following morning, and the first ten or twelve miles being particularly easy, we began to think the description of the country was only intended to frighten us ; but, by Jove! we had not penetrated three miles further on, to a place where we formed our camp, when it began to dawn upon us in earnest that there might be some truth in the statement. This was confirmed the following day when we seemed regularly stuck fast and could not proceed, and also had great difficulty in retracing our steps; in fact, the guides we had with us were in the interest of the enemy, and had taken us into a country impossible to penetrate, and though they 
were all well flogged and threatened with instant execution, it did not help us a bit. We floundered about in all directions, and at last hit upon a piece of more open country, so that, for a time we got on famously in the direction we knew our route lay. Our disappointments were most heartrending, for when we got to a bit of open country that led in the proper direction we were sure to find ourselves shortly in another impassible jungle, without the means of penetrating further; then we would have to go back and try another route.

This weary work had continued for nearly three weeks-and it seemed an interminable three weeks to us-when, one evening, a native came in and asked to see our commanding officer. On being taken to him he was found to be a deserter from the enemy who had only left their camp the 
previous day; he offered to show us the way by which we could reach the camp in a few days. He said they were in a dreadful funk at our approach, but were in hopes the thick jungles would prevent our ever finding the way to them. This man stipulated for a large reward, and that we should take him back with us to India when the campaign was over: this our commanding officer promised to do, and thus a difficult business was settled.

The next morning at daylight we started with our new guide and soon realised his value, for, in a few hours he extricated us from our difficulties and led us into a comparatively easy, open country. It really was wonderful, after the toil and great labour we had experienced, to find all going on so smoothly; and when the pioneers had to use their axes on the trees 
and brushwood, it was only for an hour or so, instead of whole days and nights, as was formerly the case. On the evening of the third day we came in sight of the high hill on which our enemies were perched; it certainly looked most unpromising, and the nearer we approached, the more difficult it appeared. With the aid of our telescopes and glasses we could see that they had erected formidable stockades on the side of the mountain, and, in some places had swung huge chains from one large tree to another; they had also erected barricades in every place where such an impediment was practicable. All this we observed as we approached the base of the mountain, and were now well assured that we had very hard work cut out for us. By the evening we had encamped on a nice open bit of ground, which it appeared the 
enemy had only lately vacated ; we occupied it and began to make preparations for storming their fortress, or stronghold, in the morning. In the mean time the officer commanding, assisted by his staff, was reconnoitring the enemy's position, with a view to attacking him on his weakest side.

The following morning we all assembled before daylight. Just as the first dawn of day was observed, we moved off and advanced in extended order, with strong supports in our rear; these were to form the storming party when their services were required.

Advancing in this way for a short distance we soon observed their line of defences teeming with people; every available man was pressed into their service and the whole country was represented. Our skirmishes now began, 
and the incessant popping was very exciting. The first serious obstacle which presented itself was a strong barricade of heavy trunks of trees sunk well into the ground and loopholed every yard or so; here they poured such a shower of all sorts of missiles on us that we were glad to retire a little and lie down until the Artillery came up. It took them a long while to effect a breach in this solid wall, but, in time they did so, and on our rushing into it, we were surprised to find it empty; the. enemy, seeing the breach we had made, knew what would follow, and prudently retreated higher up the mountain; in fact, this sort of thing continued till we neared the top, where we all knew.a final and grand struggle would ensue. We only reached this height towards evening, when our chief wisely halted for the night: in 
the mean time a strong working party assisted the horses of the Artillery, without which aid they could never have brought their guns up.

We were encamped on a partly level bit of the mountain, jutting out from its side, and fortunately were so placed that our guns could throw shot and shell into the enemy, which we commenced to do soon after daylight. After the first few shells had lighted among them, and a few round shots had passed through their stockade, we observed a great commotion which we could not understand. At last, to our immense dismay and astonishment, we beheld their whole force rushing in innumerable masses down the hill to attack us. We were thoroughly unprepared for this, such a mode of attack being unexpected on our part; all that could be done, however, was 
done, and we formed up and calmly awaited their arrival. In the mean time the Artillery was not idle, but poured in shot and shell among them with great effect, sweeping off dozens at each discharge, but this did not cause them to hesitate or waver in the least : on they came like a torrent, and really it looked, at one time, as if our whole army would be swept away by it. At last they were in among us, for, as to trying' to keep them back, one might as well have tried to turn or stem a mighty river when it is swollen with heavy rains.

Our first opponents were a body of a thousand spearmen who were pushed on by those in rear; nothing could stand in their way, for they came on with impetuosity and determination. - The party I commanded was swept away, or speared in less time than it takes me to tell it; 
and, as each of our opponents was armed with a sharp tulwar, or native sword, and in many cases a dagger also, whenever a man was disabled in any way he was immediately dispatched. I, fortunately, kept my senses, and also my legs, for a considerable time, and parried all the cuts and slashes aimed at me, disposing of several of my opponents, when, suddenly I received a crushing blow on the back of the head which made me sink on the ground without sense or feeling; with this, my recollection of what afterwards occurred, ceased.

What I next remembered was finding myself lying on a mat under a fine, branching tree, with my head splitting, and my whole body a mass of pains-so much so, that when I attempted to turn, it was such agony that I was only too happy to remain still. A young woman now' approached 
and gave me a delicious, cool drink, at the same time examining the bandage on my head which was throbbing as if it would split; and the burning, feverish pain I felt I shall never forget. She smiled on me, and said something I did not understand; then, patting my cheek, she walked slowly away and joined an older woman, to whom she appeared to be describing my case, if I could judge by the frequent glances they threw at me as I lay helpless and thoroughly incapable of moving either hand or foot. 
CHAPTER III.

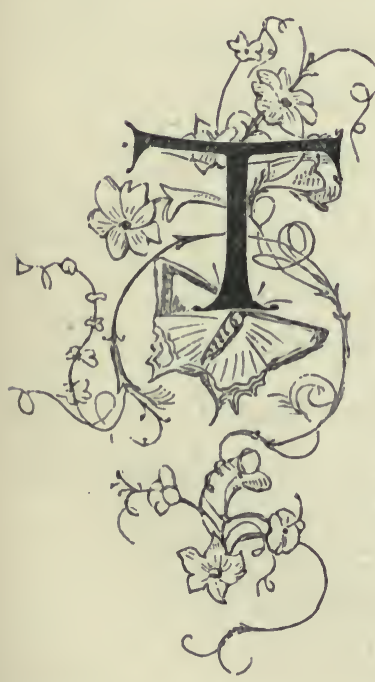

HE drink she gave me was a sedative, for I did not awake until the evening, when I was glad to observe that the dreadful pains in my head were abating, and the burning sensation was leaving me; so, feeling easier, I naturally imagined I was a little better, and could see, by my nurse's face, 
that she also thought I was turning the leaf. I lay in this state for seven weary days, when I began rapidly to recover; and no one knows, who has not experienced it, how delightful it is to feel new life coursing through one's veins where had been nothing but congealed blood and dormant vitality. I don't think any one can realise what life is, till he has been on the threshold of death; and then the delicious feeling of returning life, is one never to be forgotten.

I was meditating on what could have become of my brave companions, and thinking that all could not have been lost, for our general was a man renowned for his many resources, and his distinguished talents as a leader in the field, when I heard a cough, and, looking up, observed a native surveying me most attentively; 
as a matter of course I returned the compliment, and must own I was not pleased with the result. $\mathrm{He}$ was exceedingly dark, with a very low brow, and a particularly cunning, bad expression, and I felt my blood run cold while I was examining him. He made me a sign that he wished me to get up, but on endeavouring to do so, I fell back again on my mat; he gave a grim smile at this, and, seizing me in his arms, immediately flung me across his shoulders, carrying me off, notwithstanding that my nurse came forward to remonstrate, which she evidently did by her manner; the man said something apparently in dissent, and I was carried off without any further delay. He appeared to strike into the jungle and to traverse a path which did not look as if it was much used; but he pushed on, skilfully dodging 
the low branches which threatened to sweep me from off his shoulders.

I observed, now, the appearance of the forest was changed; the country gradually became more open, and the grass much more luxuriant. We were descending all this time, and the further we proceeded the change became more apparent, and I fancied the climate was much milder; for, I should mention that, the last few days I had felt it very cold and comfortless, which was perhaps in my favour as long as I had the severe attack of fever, but now, the fever having quite left me, I rejoiced in this change of climate.

We continued to descend rapidly, and I noticed the vegetation much more luxuriant than it was in the place I had left. My guide, or carrier, now began to exhibit signs of fatigue, which I was glad to per- 
ceive, as I felt all my old aches and pains returning from the continued jerking caused by the motion of his body. At last he said something in a husky tone, and then softly pitched me on a bank of moss under a splendid euphorbia tree, where I was only too happy to lie quietly with my eyes shut; and really, if I had been told that my last hour had come, I should have hailed the summons with pleasure, for I felt so utterly woe-begone and miserable. I now saw my guide, or keeper-whose short absence I had not noticed-was approaching me, accompanied by another native: after a short consultation I was lifted up by the new ally and jerked on his back with as little ceremony as my first carrier had exhibited. They talked earnestly and rapidly and I soon found out that they were speaking of our army; and, from their frequently 
pointing towards the south, I concluded the force had marched in that direction. It sent such a thrill of happiness through me to feel certain that some, at least, of our brave fellows were saved, that all my aches and pains seemed suddenly removed, and I tried all I could to catch the meaning of their words, but found it useless; after giving my utmost attention to it, and straining every nerve in the attempt to understand, I remained, as wise as before.

We now entered a large plain without any shade; hitherto we had been pretty nearly all the way under the shelter of trees, and the glorious coolness of their shadows was only appreciated by me when I had lost it. The heat and motion became now almost unbearable, and as I lay like a log on my conductor's back, I could not help myself at all; but, at last, God, 
in mercy, removed me from this misery by rendering me unconscious, and the rest of that dreadful day remains a total blank as far as my recollection is concerned.

I did not recover conciousness till the following morning, when I was awoke by the cool air blowing in through the bars of a prison. For a considerable time I could not imagine where I was, or what had become of me; but soon enough the sad reality slowly stood out frightfully, and vividly, chilling my very soul with the appalling picture. If I were to live a hundred years I should never forget the fierce anguish suffered at that time; but God's goodness finds a balm for every wound, and a ray of hope dawned upon me as the idea shot through my brain"Why not escape?" In a second I was a different man and had all my intellects 
as clear as ever. On looking round my prison again, I was surprised at the improved aspect it assumed; instead of its frowning massive bars, these appeared rather tasteful and elegant, and what I formerly thought gloomy and dark, now looked to my sight cool and refreshing.

On taking a more careful survey of my prison, I saw much to be thankful for, as there seemed no solidity, or serious obstacles in my way to escaping. It was a building apparently constructed some years previously; the lower portion was built of solid stone work, and the upper portion was formed of strong timber, with massive beams traversing the weaker parts at close intervals. After examining the wooden wall with deep attention, I determined to effect my escape at that part of 
the edifice. The exertion of the examination and the fatigue I had undergone on the previous day, I suppose overcame me, for I then fell into a deep slumber, out of which I did not awake till far into the night, for I could see the morning stars twinkling brightly, and I looked upon them as a cheering omen of hope and success.

As soon as day broke I could see that some one had visited my room while I slept, for provisions and an earthen jar of water had been left for my use. How I longed for my bath and the comforts of the toilet to which I had been accustomed all my life! But for the hope of escaping, which kept up my spirits and gave me courage and determination, I am convinced I should soon have sunk into an early grave. $\mathrm{Oh}$, what joy hope gives to the weary cap- 
tive! I blest her for the sweet consolation at a time when I felt myself deserted and left alone in the world, without strength or energy to rouse myself to action till her whisper brought me comfort.

I lay for a considerable time indulging in this pleasing dream, and fancying I was far away in my Irish home again, where the people and my kinsfolk vied with each other in kindness and welcome, when I was suddenly reminded as to where I was, and, in an instant, all my pleasing dreams vanished.

The key was applied to the lock in the door, and there appeared great difficulty in turning it ; from the whispering conversation outside, carried on in a low voice, I fancied they thought I had been tampering with the lock. At last they got the key to act, when the clumsy door slowly opened 
and two natives entered; one I recognised as the man who first carried me the previous day, the other had the appearance of a native of Bengal. We all stared immensely at each other for a minute or two, when, to my astonishment and pleasure, I was addressed by the latter in good broken English. He began :- "Sáhib, this fellow want to know how many of you damm fellows come to this country; he also want to know if any more are coming to be killed like old lot." I assured him I did not know, but I was certain the Honorable East India Company would not allow a single prisoner to remain in their hands; and that they would send army after army, if it were necessary, till not a a man was left in confinement. This, he, in turn, translated to my first carrying friend who, when he heard it, scowled at 
me with his sinister eyes in a most unpleasant manner, and, spoke with great rapidity and earnestness to his companion, who, turning to me, said:- "This fellow says if his advice is taken, no damned prisoners for him; he will make short work of you, for he means to kill you to-morrow morning so that Company Sàhib need not send a second army on your account."

They then turned and left me, carefully locking the door and taking the key with them. When they were gone I could hardly breathe for a few minutes with surprise and dismay. Did my ears deceive me? "To-morrow morning!" This I kept repeating to myself a dozen times over till $I$, was incapable of thinking of anything else. After lying in this prostrate condition for an hour or two, I, with a great effort, roused myself and 
began to think what was best to be done, as the time was so short. My first act was to eat as much as possible, and though the food was not tempting, I felt that it nourished and strengthened me, which was what I wanted; the water I found deliciously cool, and after a good draught I was altogether a different man. I felt my pulse; though it was weak, it was also slow and firm, and I knew I was able now to undertake any adventure that promised a shadow of success; and I thought it would be much more glorious to die in the endeavour to escape, than to be butchered in my prison in the morning, which I could see would assuredly be my fate if I did not manage to make off in the night.

This effectually roused me to reconnoitre, and to decide upon what course to 
pursue before the night fell, when no work could be done. I sprang to my feet at once, and, on examination, I found the wood-work was much more dilapidated than I at first had supposed; it was almost rotten, and a vigorous push would send out the whole wall-this I must be careful not to do, or I should alarm the neighbourhood or village, which I concluded. must surround the place of my confinement. I then selected one place that appeared more rotten than the rest, and found that a gentle continuous push would soon leave me free. This important point settled, I returned to my mat and reflected upon what direction I should pursue when I regained my liberty. We had deviated the previous day so much from our course, and had so frequently retraced our steps, that I had no idea in what direction my 
route lay. Here let me add a word of advice to my young military readers who may not have had any of my experience. When on active service, never omit to take the exact bearings of where you march from, and the place for which you are bound; a small shilling compass will guide you, and if you recollect the latitude and longitude of the place you have quitted, you will be able to put yourself in the right direction in the event of a repulse, or of being thrown out, or losing the column. By following this plan you may also be the means of saving many of your comrades. But I must go on with my adventure.

I was glad to see, after a time, that the daylight was declining, and, when once it begins to sink, it is very rapid in eastern countries. I lay as still as I could, for I 
was dreadfully excited, and in about an hour it was as dark as I could wish. I got up, walked about the room, and listened in all directions, but not a sound could I hear.

I was standing, some few minutes later, in the middle of the apartment, thinking it was time to be doing something, when I heard a gentle tapping at the door of my prison. I moved across to where the sound proceeded from, and softly asked who was there. In a second, footsteps moved rapidly away, and they were succeeded by a heavy tread which stopped at the door and shook it, evidently to ascertain if all was right; everything being quiet and the door firm, the heavy step also moved off, leaving me bewildered with doubt and anxiety. I determined to do nothing for the present, but to lie 
down and try to recover that firmness and self control so necessary in the trying situation in which I was placed; this I did, and soon recovered my usual placidity of mind.

I have no notion how long it was before I again heard the gentle tapping at the door; this time I was near it immediately, and softly asked what was wanted. A voice, which I at once recognised as that of the Bengalee, replied that if I did not wish to have my head taken off in the morning, I had not much time to lose in escaping. I considered for a moment, was this a trick to catch me? But, on reflecting that I could not be worse off, I whispered that I would be with him immediately, and then proceeded to put in practise my original plan of escaping at the place I had pre- 
viously selected. Pushing out the boards with greater ease than I ever anticipated, I mounted up, and scrambling through the aperture, stood beside my Bengalee friend in less time than it has taken me to describe it. He did not utter a word, but caught my hand and hurried me off into the neighbouring jungle, where we sat down to listen and to consult. The quick ears of my guide had heard footsteps approaching the prison as we fled from it; and, as there were several persons together, one of them carrying a light, we were anxious to see what was up. Being in a very good position for watching them under the leafy branches of the small tree which we had selected for our temporary shelter, we saw them unlock the door and slowly enter the apartment I had just vacated, and my 
guide whispered that I was none too soon in escaping, for they had come to behead me; it certainly looked like it, as one man carried a broad axe and another a block. They evidently intended making short work of me, and I felt I was not a moment too soon in getting out of their clutches. Their cry of disappointment I shall never forget when they found I was not there, and on further search saw how I had escaped. My Bengal friend assured me the language they used was very strong, my first acquaintance consigning me to a very hot place; but, as nothing could be done till daylight, they all retraced their steps sadder, and, it is to be hoped, wiser men. They should have learned the pretty little motto which is taught to all our juveniles :- " Never defer till to-morrow what you can do to-day;" 
but, not having had the benefit of an English education, they let me slip through their fingers! I offered up a silent thanksgiving to God who had preserved me from such a fate, and a prayer that $\mathrm{He}$ would continue to protect me.

My guide now whispered that it was time to be moving; we got up at once and penetrated into the thick of the jungle, where it would have been impossible to see us, concealment being our great object, for we knew that at daybreak pursuers would be on our track; and, from what I had already experienced, my readers can understand I had no wish to be retaken. By the time it was daylight we were some three or four miles from our starting point; it may appear strange that so little ground was got over, but no one who has not tried it, can 
form any idea how slow and heartbreaking it is to makes one's way through an unknown and dense jungle at night. This is the reason our Creator has furnished nocturnal animals with long whiskers, in order that they may feel their way; but, not having any myself, my readers can fancy how I floundered in the darkness, hurting my shins at almost every step.

We were dreadfully tired and exhausted when we decided to encamp, having first pulled a quantity of long Indian grass to make our bed under a thick bush, and we had hardly lain down when we were fast asleep. It seemed to me that I had scarcely closed my eyes when I was awoke by having my shoulder painfully and continuously pressed. I looked at my companion, who was green with terror; and, 
turning to where his eyes were fixed, I saw, to my horror, a huge Cobra swinging himself by his tail from a branch of the very tree we were under, each swing bringing him a little nearer our heads: his forked tongue was out, and his red, fiery eyes were fixed upon us with a most malignant expression. I sank down on my bed in mute stupefaction, thinking I had done for ever with all the worries and cares of this life, when a cry of joy from my companion again roused me. It appeared that just as the snake was about to dart at one of us, he spied one of his deadly enemies-a mongoose-quietly taking stock of him, and this so upset his nervous system that he could not stand it, but sloped back, to the great relief of myself and my dusky friend.

We had received much too great a 
fright to think of again sleeping, and, as it was then about mid-day, thought we would "make tracks," while we had an opportunity of doing so. My spirits rose wonderfully, and though we had nothing to eat, and hardly knew in which direction we ought to go, still I felt joyous and happy; the jungles were magnificent, teeming with flowers and lovely plants, and the songs of the birds, with the soft cooing of innumerable doves, all contrasting so favourably with the life I had been leading for the last three weeks, it was no marvel I felt my spirits so elated, and that joy and gladness had succeeded to pain, gloom, and misery.

We lost no time in starting, knowing that every hour we remained in the vicinity, our danger and our chance of recapture were increased. Our way led 
us alongside a pretty. brawling stream, and we had to advance very gently, it being necessary to reconnoitre every bit of ground before venturing to show ourselves in the open. By this means we got over a much greater distance during the day than any one would imagine, and when twilight began to creep on, we were glad to lie down for the night. Our food was a great source of anxiety, and how to procure enough to sustain us we did not know; we had been fortunate in finding a good supply of honey, which had lasted us thus far, but, procuring a dinner was more than we could promise ourselves. Even if we had had a gun, we should have been afraid to fire it, as it might have alarmed the whole population; so, all things considered, as we were situated, perhaps it 
was best to get along as we were doing.

I had such a fright the last time I lay down, that I could not sleep for nervous fear, and looked out in expectation of a snake making its appearance on all occasions; but, fortunately, nothing came to prevent our enjoying a thoroughly good night. We both awoke the next morning completely refreshed, and set off as soon as possible. This day we frequently saw numbers of natives herding their cattle in the fields, and once my guide ventured to ask what had become of the soldiers, but they professed not to know anything respecting them., We managed to buy some dál (a kind of pea) from these men, and for the first time for many days I, made a full meal. This renovated us greatly, and we got over a good bit of 
ground before dark; but, as I said before, making a way through a thick jungle was particularly slow work. The next night we slept in an old hut, and I must own that I felt much safer, having a door to close, though it was only a mat that represented it.

Having heard from some shepherds that there were a good many natives in the neighbourhood, and that we were close to a very large village, we determined to get away before any of them were about in the morning. We, therefore, started before daybreak, but not knowing the direction we ought to take, missed our way; before we could rectify our mistake, we took a wrong turn, and found ourselves in a large village crowded with fighting men -if one might judge by the way these fellows were armed, and the formidable 
appearance they presented to our astonished eyes. They gathered round us at once in a menacing attitude, and I saw in an instant that we were prisoners; we were hustled at once into the presence of the kotwäl, or head man of the village, and, as he had not time to question us then, he directed that we should be "taken care of till the morning," which meant that we were to be shut up in a strong room and guarded by a sentinel, who would pace round the hut all night. I was filled with astonishment and dismay at the dreadful fix we were in, and my Bengal friend quite shook with agitation when we talked over our new position; he, however, told me a bit of cheering news, and this was that he had observed a man among the crowd whom he had known formerly, and that this man had 
made him a sign that he would help him.

Our mats were then brought in, with some dál and water, after which we were locked up for the night. I was so tired, and had grown so indifferent about my fate, that I soon fell asleep, and continued to sleep till the morning, when I arose wonderfully fresh; after I had eaten my breakfast I was up to anything that might happen, and did not feel the least alarm at the prospect of being brought before the $k o t w a \bar{l} l$ and all the wise men of the tribe, who were to sit in council, although upon their decision rested our chance of release, and perhaps much more.

In a very short time we heard the tramping of many feet, our door was thrown open, and we were told to follow the man who now came to fetch us, which 
we, of course, did; when in the street, I could see by the angry faces of the crowd that we were not especial favourites. We soon reached the palaver house, which consisted of a large hall with raised seats one end, on which sat the kotwäl as president, and some half a dozen old men who formed the council. The kotwail, or chief magistrate, was a sinister, hard, cruel looking fellow, with a low, cunning expression, anything but agreeable to contemplate for men in our unhappy situation. We were not left long to make our observations, for, on our being called up, the examination began. I soon found they knew more of us than we suspected, and they were quite aware of my escape having cheated the executioner; indeed, there was my captor himself, sitting in the hall, his bad, disagreeable fare quite lit 
up with smiles at my recapture, and delighted at being in time to witness my execution, for it appeared that he had just arrived from his own village, from whence he had been summoned. It seemed with all our hard walking that we had only got away about twenty, or five and twenty miles from the village out of which we had escaped; walking in a thick jungle is so deceiving that you may fancy you have gone treble the distance really traversed.

The examination proceeded, and everything seemed to go against us. It appeared, from the evidence, that I had invaded their country, gone about killing the inhabitants and burning their villages; and, after doing all this damage, I had not had the common politeness to remain with them till I was executed! They all rose 
as one man and condemned me to death; they were thoroughly disgusted with me and wished to put an end to me. My former enemy hinted that he could take my head off conveniently just outside the door, then and there, but, fortunately for me, this offer was overruled and the pleasing and interesting spectacle deferred till the following morning. I was marched off to my prison by myself and locked up securely; I could see the sentry walking round the hut, as he had done before, and no doubt they took greater precaution than ever, to ensure my certain destruction this time.

In the evening, when my food was' brought in, I observed the man when setting it down, give me a peculiar look, and as soon as he and his companion had retired, I narrowly examined all the things 
which he had brought me: at first it crossed my mind that the dál or the water was poisoned, but then I thought they would never deprive themselves of the grand exhibition which was to take place in the morning. I examined the walls carefully. to see if there was any chance of forcing my way out of this prison as I had done in the previous case; but this building was all stone, so that was impossible. I then sat down to eat my last meal, as, at the time, I fancied it would be. I had hardly commenced when I came across a bit of paper folded up, or, rather, twisted into a roll; on untwisting it I saw scrawled in English :-_ Be ready. Midnight." It immediately occurred to me that the friend who had recognised my companion on the previous day, was the sender of this note, and my heart leaped with joy at the pros- 
pect of again escaping out of their cruel hands.

It still wanted some hours to dark, so I tried to go to sleep, and at length I succeeded in dozing; but I was continually starting up, thinking I heard tapping, though I knew it could not yet be near midnight. At last it grew near the time appointed, and every one had retired to bed, if I might judge by the extreme quiet that reigned throughout the village. Then I began to be dreadfully anxious as I listened to the steady tread of the sentinel passing round and round the hut. I heard a key turn in the lock just after he had passed my door, and it was gently pushed open; I was through in a second, when the door was again pulled to quietly, and locked. My new companion had just time to run with me 
round the corner, when the sentry came up to the entrance, but no suspicion seemed to have crossed his mind, for he passed on while we kept a little in front of him.

My guide now pressed my hand encouragingly, and ran to the back of an adjoining hut, and I was not slow in following; we crept on, dodging behind everything that could screen us from the sentinel's sight, and in this way walked safely out of the village. We then made for a tall tree a few hundred yards distant, and, on reaching it, found ready for our use, two native ponies, or tattus, held by a sais, or native horsekeeper; my guide quickly jumped on one, and $I$ on the other; we rode off at first at a walk, or amble, at which pace the native ponies excel, gradually increasing the pace to a 
good round gallop, which we kept up for several miles, but had to leave the high road frequently, and make a detour to avoid passing through villages. Fortunately, as we had not met a creature, no one could give information about our movements, so we jogged on comfortably, but silently, as I knew but little of my companion's language, and his stock of English was mighty small. By making play whenever the road was tolerably good, we managed to put a good many miles between us and the village we had quitted at midnight.

It was just coming daylight when my guide, to whom I submitted wholly, turned off from the road and entered the jungle, with which he seemed to be quite at home; after riding through it for half an hour, he drew up in a thicket, and we 
dismounted, unsaddled our tattús, and hobbled them to let them graze; and, as there was some water near, we felt they would soon help themselves.

Who can describe the glorious feeling of liberty under such circumstances as I enjoyed it? To have exchanged the loathsome dungeon, with the certainty of a cruel death in the morning, for the beautiful jungle with which I was now surrounded, to hear the soft cooing of the doves, and the gentle rustling of the trees as the morning air floated through them, made me involuntarily send up a prayer of thankfulness to the Giver of all good things. My guide, who appeared to have forgotten nothing, now produced a bundle wrapped up in a clean cloth, which, on his opening it, displayed a fine cold roast fowl, with a good supply of chupatties 
(a native bread). This we spread out on the grass, and both set to work without a word being spoken; indeed, I could not induce.him to answer a single question, and to all my anxious enquiries, he only put his finger to his mouth, as much as to say, "Shut up for the present." After we had taken the edge off our appetites I found him disposed to be a little more communicative, but he was dreadfully cautious, and always peeping out to reconnoitre, when he would remain away for an hour at a time; he evidently expected a. sharp pursuit, and, as the sequel will show, he was not far wrong in his surmises.

We had rested probably for four or five hours, when we heard the ga!loping of horses which took my guide immediately to his post of observation, and I had the curiosity to follow him, 
much against his will, for I believe he had a very poor opinion of my judgment in this sort of pursuit. We had heard the noise of the galloping a long way off, and the jungle was so quiet now, that hardly a sound was heard excepting that of the horses' feet. On their getting near I discovered the party were ten in number, and, on their approaching closer, I observed the kotwall at their head, who was most energetic in pointing out the likely spots in which he thought it possible we might be concealed. I also saw my enemy among them, looking quite downcast and melancholy at having lost the chance of cutting my head off; he rode along with his eyes down, and seemingly much depressed that the pleasure had again so mysteriously slipped out of his hands. They had, by this time, reached 
the spot where we had turned off from the main road, and the quick eye of the kotwail immediately observed the marks of horses having moved off; there was an immediate halt, while some of the party dismounted and narrowly examined the hoof marks of the horses.

My guide, who was well up to his work, signified to me that I must follow him, which I was only too willing to do. We retraced our steps and followed the course we had come, only keeping under cover of the bushes and high grass. On our getting half a mile to the rear, we approached the main road, and, after a good look round, crossed it at once; then seeking the nearest cover, we continued our backward route, only keeping more to our right and getting as far from the road as possible. I now began to see the wisdom 
of my guide's tactics, for the chances were that our pursuers would not think of following us in the direction we had chosen. We gave up our tattús for lost, as indeed they were; but they had done their duty nobly by us, and we could well afford to spare them now, when we dare not show ourselves on the high roads, but must be content with lying up all day and travelling at night. Now approaching a dense jungle, which abounded in snakes. and tigers, my guide quaintly remarked, in his bad English, that it was not likely they would make a very close search for us there, if, indeed, they would venture to follow us into it at all. We did not penetrate far before coming to a clearing on which we threw ourselves, and, feeling tolerably safe for the present, determined to remain where we were till the pursuit 
had cooled a little; for, finding our ponies, we felt assured, would give our pursuers great confidence. 


\section{CHAPTER IV.}

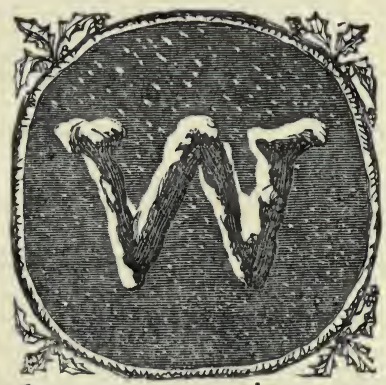

E lay concealed for the remainder of the day, and nothing happened to annoy or disturb us, but my guide assured me that not a native would be persuaded, for love or money, to enter that terrible jungle; he said there were nearly as many skeletons of human beings in it as trees. When a tiger killed a native-and this was almost a daily occurrence-he carried him off to this wood to devour him here at his leisure, as he was sure not to be 
disturbed in the middle of his repast. I enquired why they did not burn the jungle or cut it down, but he said it was too green to burn, and too extensive to be cut; and another great objection was the expense, as no one would pay for the work: most probably things go on there in the same way, to the present day.

We proposed that one should sleep while the other kept watch, which was agreed to, and carried out at once, I being the first sentinel. My companion was soon in a deep sleep, and I proceeded to examine him, as I had not had an opportunity of doing so before. I had been struck with the smallness of his hands and feet, and the slightness and activity of his form while we were travelling together: his head was concealed by the turban, which consisted of a thick cloth wound 
round it many times, and then rolled round the face so that all was invisible excepting the eyes, with an occasional glimpse of the nose. I now felt greatly inclined to take a peep; no sooner said than done, and to my intense astonishment, I beheld my nurse, the girl who tended me in my great illness, whose partiality for me; doubtless, was the cause of my first carrying friend being so bitter against me, and pursuing me with so much animosity. I covered the face up very gently, and then sat down to meditate, when I decided it was more prudent, for both her sake and mine, that I should say nothing of the discovery I had made, but let things take their course; for, if she knew I possessed her secret it would embarrass her, and might have the effect of inducing her to leave me alone 
to my own resources, which would simply end in my ruin.

I lay down to think over this subject, and the more I meditated upon it, the more perplexing it seemed; to be travelling about the country with some one's sister or wife was a grave addition to my offence of being still alive in their country, after the decrees they had issued concerning my death. I now observed that the sun was rapidly sinking in the horizon, and, as I knew now the sex of my faithful guide, I resolved to spare her the responsibility as much as possible, for I observed she shrank from it whenever she could. I did not at all fancy being in the plain when night fell; it would be an invitation to the tigers to make their late dinner off us, and, for my part, I did not like the idea of being snapped up like a young 
lettuce; so I looked about me for shelter, and, after a little, I selected a fine, stately yew tree, full of foliage, with its branches extending out from near its stem. I thought this would be the very place in which to pass the night, and blessed God for putting the idea into my head.

I soon climbed up the tree and found it just suited our purpose; the branches were thick and numerous, and well forked so that we could repose comfortably when a safe distance from the ground. I then descended and saw we had no time to lose if we meant to take possession of our new habitation; so, rousing my companion with some difficulty, I told her what I intended to do, and, partly by signs, and partly by language, made her comprehend my meaning : she gladly acquiesced, and I could see this arrangement of mine gave 
her very great satisfaction. We soon reached the tree and were not long in ascending to the upper branches, where we made ourselves as comfortable as circumstances would permit, and had hardly done so when the night fell, and there was not a glimmer of light left. I felt rather proud of my arrangements, and also of having carried them out while daylight lasted, for, if we had postponed them even for a few minutes, I question if we should have been able to find the tree.

By this time the whole jungle was filled with the most horrid noises imaginable, from the unearthly laughter of the jackal to the shrill trumpeting of the mighty elephant, and the startling roar of the tiger. I felt my companion trembling; but feeling herself securely seated, and being able to support each other when 
necessary, she was soon reassured and encouraged. Poor little thing, she seemed greatly agitated, and it was some time ere she recovered altogether her natural firmness and courage.

About midnight the moon was shining magnificently, and I amused myself looking at the various animals passing our tree. First a herd of stately elephants would slowly pass, browsing on the branches of the bushes and the tops of the young trees; they were hardly out of sight before a herd of deer would approach, headed, perhaps, by a noble black buck, and this is, in my opinion the very handsomest animal we have in the East. Then, a huge tiger would crawl after them, sneaking along with his belly almost touching the ground, as if he were only there on sufferance. Certainly there 
appears little of manliness on the part of the tiger, for, unless he is starving or badly wounded, he can seldom be induced to charge; he is much more inclined to sneak off into the thickest of the jungle, where, towards evening, he can crawl to its outskirts and watch from under a bush, ready to dart upon some hapless native unconsciously passing, when he drags the mangled form into the jungle to be eaten at his leisure. I know it is the custom to praise the tiger, but he is no favorite of mine.

Before the day dawned we began to feel frightfully hungry, but, as we had nothing to eat, the less we thought of it the better; though I determined in my own mind that, as soon as it was light, I would procure something for my companion, if possible. After a time daylight 
slowly made its appearance, and then we saw all the animals coming back to their lairs after their nocturnal rambles. Elephants, deer, and tiger, all re-passed pretty nearly in the same form as they had proceeded outwards.

I observed a jungle cock hovering about a bush adjoining our tree, and then, seeing the hen appear, it struck me we might get an egg there; so, after waiting a little while, I hastily descended the tree, and, anxiously peeping about, discovered the nest with nine eggs in it. Here was a godsend! With grateful heart I stowed them away in my pocket, and, calling to my companion to descend, we made a hearty meal on the eggs: after this we felt much strengthened and more able to think and decide upon what was best to be done in our trying position. I was for 
starting off at once, but my companion would not listen to it; she gave me to understand that the whole country would be on the look out for us, and we should not be half an hour out of the jungle before we might be captured by some one who would give the alarm; so we decided upon remaining where we were for the day, and to be guided by circumstances on the morrow.

My guide slept-or pretended to sleep - most of the day, and it passed so slowly that I was glad when I saw the sun beginning to disappear in the west. We then mounted the tree as we had done the previous night, and saw the same procession of animals pass, and return in the morning, when we were much pleased to find a couple of eggs in the jungle fowl's nest: on my penetrating further into the 
wood, I was fortunate to find also a large nest of honey, enough to last us several days. With the eggs and the honey we made a splendid meal-such a meal as I had not seen for some time.

My companion looked dreadfully worn and low spirited, and I often saw her in tears when she thought I was not observing her; this I could not account for, but how was I to prevent it? It was no fault of mine that she had placed herself in such a predicament; but I reflected that the sooner I got rid of this selfish idea, the better; for, without this generous girl's aid, where should I have been now? Most likely a ghastly skeleton in some dense jungle with my head hung up as a trophy, and at the same time, as a warning to future intruders.

I got so weary-so very weary of this 
sort of stagnant life that death was preferable to it, and I resolved to make a start the next morning; I think my guide was equally glad to leave our tree home for one more congenial to her tastes and habits. The sun was just rising when we made our breakfast on the last of the honey; and then, with light hearts, we made the best of our way out of the friendly wood which had been our home now for some days. We were much nearer the open country than I could have imagined, and, when we fairly got out into it again, I felt so elated that I was equal to walking any distance, but, I observed my companion was not in so fit a state for a long pedestrian journey; however there was nothing for it but to put our best legs foremost and be thankful it was in our power to do so. 
After a consultation we decided upon going in a southerly direction, as we thought it would take us more speedily out of the way of our implacable enemies, and the result proved we were right. The whole of this day we kept on crawling from one jungle to another, and if we saw men journeying, or minding cattle in the fields, we crouched down under bushes, lying still till they had moyed on and were out of sight. One shepherd gave us a a great deal of trouble; he saw us and could not make out what we were doing, and his curiosity induced him to stare hard at us, continually stopping to stare again, which alarmed us, and I need not say that when he at last moved off, we were not long in following his example. No bad result followed, but I often wonder if he informed against us, for I am quite 
sure every one in the vicinity had heard about our escape, and were directed to give instant information if we were ever seen.

We got over only a few miles in the day, but when night came we pushed on more boldly; it was brilliant moonlight, which was better for us than the sunlight and much cooler. Wild beasts were very numerous, and it required great caution on our part to avoid them, and if we came near a village, we had to take a long detour to escape notice; still, we pushed on steadily, daily gaining a greater distance from the scene of our misfortunes. We had now got so far away that we relaxed our rule about travelling only at night, and my companion could venture into the villages to bring provisions and any little articles we 
required; for I found she had not come away without money, of which we now began to feel the great benefit, and I did not hesitate to use her money, as I hoped to repay it tenfold some day. We could not hear a word about our army; and, such was the ignorance of the natives, that, I believe, unless the troops had actually marched through their own villages, they would not have known anything at all about them; indeed, we had gone now so far from the scene of our fighting, that many of the natives we spoke to on the subject had not even heard that the "Faringees" had invaded their country.

One day when my guide went to a village to bring some food, she was told that a sick stranger had been resting there for a few days. By the description of the 
man she fancied it might turn out to be the Bengalee who had interested himself so kindly in my behalf before my last capture, and, on seeing him, this proved to be the case. She brought him with her to me, and delighted was I to see him again. $\mathrm{He}$ had heard about the movements of our army, but I had so many questions to ask that he said he must rest before he could give me the information I required, as he had been very ill, and the walk from the village to the top of a tree-my halting place-had quite knocked him up; but he assured me he had news for me that would "make my face white," which strictly speaking, it required very much, for water was a luxury I seldom had the opportunity of indulging in; and, as to soap and towels, they were things of the past that I just recollected, 
and hardly ever expected to see again! The Bengalee meant that his news would fill me with joy, but in the native language they would use the idiom, "whiten your face." I felt much elated, as I knew he had something pleasant to tell me, and I had supped so much sorrow lately that it was time I should have my innings on the other tack.

My friend now lay down, and was not long in going to sleep, and I watched him, -longing for his awaking. He slept wonderfully sound, and, as the afternoon wore on, I felt sorely tempted to rouse him, which I did at last by an assumed fit of coughing. He sat gazing at us for a few minutes on first awaking, before he could recollect where he was, and then he began to give me the information my heart longed to hear. 
To my great joy I heard that our army was safe. And I also learned something of what had happened after I had received the fearful blow on my head which had been the unhappy cause of my long separation from my regiment. It appeared that although the party I commanded had met with a reverse at that moment, owing to the tremendous and overwhelming force of the enemy pouring down upon them, yet, that lower down they were met by troops more prepared for them: and, though our troops suffered most severely, they were able to stem the torrent and eventually drive them off; and at last succeeded in taking their stronghold, which however, was not a very difficult matter, as it was quite denuded of troops, for, as I said in the previous chapter, the Nepaulese could not stand the shells bursting in among 
them; and the round shot cutting through them, after it had penetrated the walls of the stockade, made it too hot for them to remain. I believe, from what I now heard, that our loss was much less than if we had been allowed to storm it in the usual manner. The Bengalee did not know where our troops were, but he understood they were marching out of Nepaul after having effected all that had been required of them. The enemy was to pay a very heavy indemnity for the expense of the war, and had promised to behave better for the future.

This was most gratifying news for me. Instead of sneaking through the country as I had been doing, I now intended to assert my right to respect and assistance as a British officer who had been left behind wounded. Acting at once upon this, 
I went to the kotwal of the village, to his surprise, for no one had the least idea where I had sprung from. I demanded a horse and an escort to the next village, and, in the meantime, a hut to be assigned to me during my stay in his district: I also asked for the use of two tattús for my followers, and afterwards ordered one of the bazaar merchants to be desired to attend on me with patterns of cloths from which to select a suit of clothes-not before I wanted them, as I was nearly reduced to rags, and they were in a filthy condition. The chief magistrate expressed the pleasure he felt at seeing the sáhib safe and well, and said he and everything he had, was at my disposal, including even his wives and children. $\mathrm{He}$ said that if I would rest for a few days, by that time he could procure a horse that was 
worthy to carry me; indeed, he knew of an animal which had belonged to one of the gentlemen of the army, but had unfortunately been lost by him; he knew where the man lived who had found him, and in two days he should be mine. No doubt the fellow stole the horse, but I was not in a position to look too closely into matters of this sort, so I gladly consented to remain the kotwāl's guest for a couple of days; and, in the meantime, the darzi (native tailor) was hard at work making me some presentable clothing of which, as I observed before, I was sadly in need.

I was soon lodged in a cool, comfortable hut, and every attention shewn me; I hired a few additional servants whom the Bengalee superintended for me, the kot$w \bar{a} l$, from his own table, sending my meals, which consisted of roast and boiled 
meats, poultry, game, and the most delicious curries I ever tasted. The Indian curry is much superior to that made in England, as the vegetables and herbs supplying the curry stuff are gathered fresh every day or so, and this causes the flavour of the dish to be much finer.

The following morning the kotwāl came to enquire how I was, and if I had anything to complain of which he could remedy; I told him I had no complaints to make, but that I should require a thousand rupees (a hundred pounds) by the following morning, for which I would give him a bill on the English Treasury in Calcutta. To this he made no objection, but said he would like to present me with the money if I would accept it; but I was firm in insisting it should only be a loan, and that I would repay him as I had 
proposed. Soon after this he departed, much to my relief, for the natives have no great feeling in common with us, and if he had sat another hour we should only have been paying each other compliments all the time. My stock of Hindostanee was not very extensive, but I could make myself understood pretty well; and now, being thrown entirely among natives, I acquired much more of their language: I seldom heard a word of English spoken, and was obliged to use what I could command of Hindostanee:

When I compared my present position with what it was four or five days ago I could hardly realise it, and I frequently shuddered when I thought of the tiger jungle, and of the dungeons I had occupied, awaiting execution in the morning. And here I should mention, that on taking up 
my abode in this village, my faithful friend, the Nepaulese girl who had helped me to escape from prison, and who had so unselfishly followed me ever since in my wanderings-resolved to return to her own village. Her strength had been unequal to our hard life and many privations, though I think she would even now have remained in my service had I required her assistance; but I found a girl rather out of place among my followers, and urged her to return to her home without delay. I was now able to repay her in money all she had so generously advanced for my necessities, adding, of course, as handsome a present as my circumstances would allow; and, this debt being discharged, I felt that I could do no more than restore her to her home in safety. The Kotwāl good naturedly assisted me in providing an escort for her, which 
was the more necessary as her nerves had been much shaken by all the dangers and difficulties she had passed through, to say nothing of the insufficient food.

My host continued his kind hospitality and in a few days the horse made his appearance, but he gave me the idea of having been starved; he was a fine looking grey Arab, but wanted flesh, and had a sore back which had evidently been greatly neglected. I did not recognise the horse as one I had seen before, but this was not to be wondered at, as nearly all the Arabs are grey, and every gentleman rode one in those days; they were much cheaper than they now are, as a good one could be procured for some four or five hundred rupees, whereas now you would pay a thousand or twelve hundred rupees for the same sort of animal. This horse embarrassed me a 
good deal; he, as I have said, was dreadfully thin, and his back so bad that it would have been great cruelty to put a saddle on him; so I was perplexed, and did not know what to do till my Bengalee came to my assistance with advice which I was only too happy to follow, but I confess so artful a dodge would never have entered my own brain.

He said:- "This dam horse too much thin; he disgrace to a bára Sáhib: Master must get koprá for horse and tie him up in it, and roll his legs up, and have him led by master's sais." Which meant that the horse was much too thin for a great gentleman like me to ride; that I must buy clothing for him, and put bandages on his legs, and have him led by the horse keeper, and then no one would know what a disreputable brute he looked! In the 
meantime it was decided that I was to buy a tattú for myself to ride, and thus it it would be supposed I was using my hack to save the valuable horse who was led along in clothing. It wassoon known in the bazaar that I wanted a good tattu, and by the morning several very nice ponies were brought for my examination; after much riding and inspection, my choice fell on a pretty, plump little fellow who had been carrying a fat old saudágar (native merchant), and he was understood to be very quiet, sound, and enduring. I paid eighty rupees for him, and subsequently found that a better little animal was never foaled. He was about twelve hands high, with a pretty head and well arched neck, and he went at the pacing shuffle, or amble, that the natives delight in riding: it is certainly the best pace for getting over 
the ground, and it is so easy for the rider that it was no more fatigue than sitting in an arm chair. My pony was a piebald, a favourite colour with the natives, and the lower half of his tail was dyed pink, which they also consider a great beauty.

I decided upon starting the next morning, and rode my new purchase round to take leave of the kotwa $\vec{a}$, and to thank him, in the name of the Honourable East India Company, for his kindness and hospitality to me. He received me in quite a fatherly manner, got up and embraced me, and, on my leaving him, he blessed me in a way that was quite patriarchal. The kotwäl was evidently much impressed with my altered appearence, for, in no part of the world are appearances so much thought of as in the East; and, on the old principle about "fine 
feathers," and the piebald tattú in addition, I fancy I won the old gentleman's heart. At the last moment he handed me a handsome double-barrelled gun, saying :- "I have had this lying by for some time, and it will give me great pleasure if you will do me the honour of accepting it." I was delighted at the old man's generosity and forethought; and, although the Honourable East India Company's Sáhibs prohibited an officer taking a present from a native, still, feeling that mine was a most unusual case, I at once accepted the offer, only too delighted to carry home my prize. On giving it a trial I had the satisfaction of finding it a first rate gun. I tried it at a squirrel, knocking him off a tree at a great distance, and, when I picked him up, he was stone dead; this I considered a fair test 
of the killing properties of my new acquisition.

I did not fancy taking so many things from this liberal old man, for it was repugnant to my feelings to be under obligations to any one, more especially to a native, but I resolved that he should one day be repaid in full for anything he had presented to me; and in this manner I contented myself. It is always painful to a gentleman to be under pecuniary obligations to a stranger, but it now seemed to me I had no help for it. I had many calls already upon my hundred pounds borrowed from the kotwall, and I required as much as I could save to help me on in my future wanderings. I lost no time in sending into the bazaar for powder, shot and caps, and was fortunate enough to obtain all I wanted. The kotwäl had de- 
sired his attendants to put up provisions for my journey, which they had done; therefore, for some days I knew I should fare splendidly; but, after that, I should have to return to the fowl curries and chupatties - these chupatties, or cakes, being the substitute for bread all over India when on the march, or out of cantonments.

There was little now to detain me here, so I made up my mind to march the following morning, and gave orders to all my establishment to be ready by daylight. Having nothing particular to do I strolled through the bazaar and spent an hour or two in examining the shops and their contents, but saw little to induce me to throw away money. Nothing is to be purchased of the natives without great bargaining, and I was not in the mood to waste time over this always disagreeable proceeding, 
and I did not care to encumber myself with purchases which would be useless. It was now beginning to get dark, and, as I was still suffering from weakness-for I had been slow in picking up strength after my late privations - I knew that the night air was dangerous for me, and lost not any time in making for home; it was well that I did so, for, darkness coming on quickly, and I, not being familiar with the various turnings in the streets, managed to take a wrong one. After wandering about some time, I fortunately came upon my Bengalee, who, finding I was late in returning, had come out to look for me, and I was highly pleased to see him just as I needed his aid. We now proceeded home as quickly as we could, and I was astonished at my extreme stupidity when I discovered that I must have passed frequently within 
a few yards of my house and never recognised it. I suppose it looked somewhat different at night, and, with all the bustle of people shouting and talking around me, my wits were deadened.

My dinner had been awaiting my arrival for some time; it was at once brought in, and I flatter myself I did ample justice to the good things placed before me: but what did me more good than all was a bottle of East India ale, which seemed to throw life into my veins; but it got up into my head from the fact of my not having tasted wine or ale for a long time. The few days I had been the kotwāl's guest I had resisted this luxury, dreading it's effect upon my head in my weak state; but on this last evening I resisted it no longer, and realised how weak I still must be, as it sent me off to 
sleep before my meal was over, when my faithful Bengalee carried me to my bed, and I never awoke till the sun was up on the following morning. Thus I passed my last night under the protection of my friend the kotwall.

I found all my servants ready for a start, and was not sorry myself to get away, as I experienced such a longing to be moving towards civilization and society, for, as I have said before, there is no companionship between a black fellow and a white man; one never seems to have an idea in common-at any rate, I can assert this with regard to any I have met. Of course I am not including in my remarks the high class natives, who, as a rule, are well educated and courteous men. 

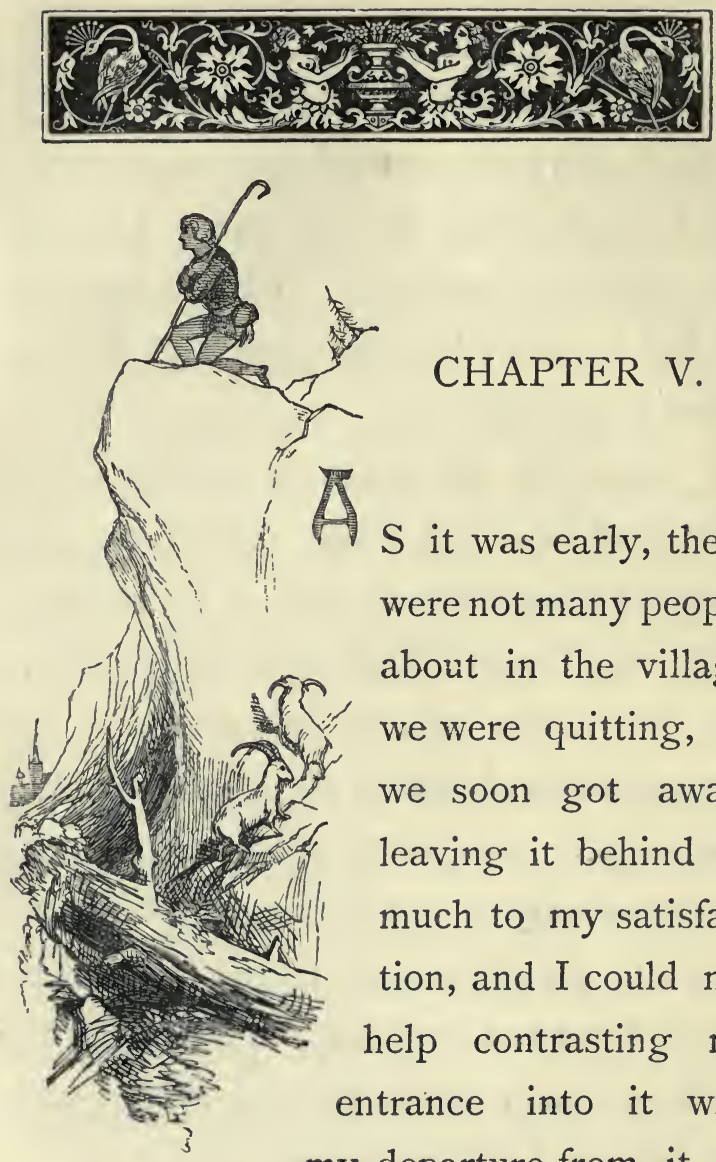

CHAPTER V.

$\mathrm{S}$ it was early, there were not many people about in the village we were quitting, so we soon got away, leaving it behind us much to my satisfaction, and I could not help contrasting my entrance into it with my departure from it. I arrived a poor, worn out, half starved fellow, and I left it improved in health, 
and, as a gentleman should travel, with every thing requisite for health and comfort. I had also provided two tattús for the use of my followers; a tent, which I had been fortunate enough to procure, had been sent on the previous night, and I hoped to find it pitched and breakfast ready on my arrival at the place where we should complete our twenty miles march. I found the Bengalee a most obliging and thoughtfull attendant; he appeared so much to study my wishes and tastes that I often marvelled at my good fortune in picking him up: the adventures we had passed through together, had brought us to think of each other more as friends than master and servant. He told me he had been in an officer's service in Bengal; had afterwards married a girl in the village where he had first joined me, and assisted my 
escape from prison. He had seen at that first interview, when he acted as interpreter, notwithstanding all the dirt and blood on my clothes, that I was a Sáhib, and had at once determined to befriend me, and if possible to assist my escape; events showed he carried out his intentions well, for I do not know what would have been my fate but for his kindly help. Since then his wife had died of fever, and he said he had now no wish to return to the village, so there had been no difficulty in enlisting him in my service once more. We rode along together on the march, and I found him a shrewd, observing fellow, one also who looked sharp after number one-second nature in a native of India.

We reached our tent safely, and everything was ready for my breakfast; steam- 
ing hot coffee, devilled kidneys, grilled chicken, and last, but not least, a partridge curry. I made a splendid breakfast, for, the fact is, I had not yet got over the dreadful starvation I had undergone while making my escape. Honey and jungle fowl's eggs are very good things occasionally, but, for a hearty man to make his daily meal of them is another thing-particularly when they form the only ingredients of the meal. I often now think of the starvation and misery of those dreadful days, but I do not in the least regret that I passed through such an ordeal, for it makes me accept with gratitude the blessings and the luxuries which I now enjoy. I affirm that there is nothing so good for a young man as "roughing it," and the more he has of it the better; in my case, however, I confess 
that, at the time, I considered there was too much roughing it, and the want of proper food, I feared would tell much against my constitution, but I am thankful to say I have never felt any lasting bad effects from the privations and hardships I was forced to undergo.

In the cool of the evening we did another few miles, as I became impatient to press on. The following morning our march was, at first, a pleasant and peaceful one. The country we passed through, for a time, was highly cultivated, the ditferent corn enclosures being very pretty and home-like; we did not pass through the village, as it did not lie in our route, nor did we see many natives about. Riding along a footpath through a barley field, I was surprised to see a couple of splendid deer jump up out of the corn and stand 
staring at me with their soft, startled eyes; but this was only for a moment, and then they bounded off at their best pace. They had evidently been asleep, and it took them a few seconds to wake up sufficiently to understand that I was not one of themselves. What an opportunity this would have been to secure some venison if I had had the good fortune to have my gun in my hand! But it was, unfortunately, packed in its case, and stowed away in the hackery, which was creaking along some two or three miles in the rear,

Towards the end of our march I overtook an old baniyá (shopkeeper), mounted on a miserable, little, half starved tattú; it was a regular bag of bones, but it still appeared to carry him safely and well. To judge by the size and stoutness of its 
rider, he was a wealthy native. You can generally, in India, tell the length of a man's purse by the state of his plumpness; and, judging in this way, of my new companion, he must have been a regular Crœsus as far as riches went. He told me he was the owner of a great deal of land in the neighbourhood, and that he was then collecting his rent. $\mathrm{He}$ also informed me that monkeys abounded in the district to such an extent that they were quite a scourge to the inhabitants in the adjacent villages; and if they were not killed, or driven off, that his tenants would be; as these pests would destroy all the crops when they were ripe, and carry away the corn into the thickest parts of the jungle, where it was impossible to follow them. Their daring was such that they actually attacked a village where one 
of their number had been killed; and, although the whole population had turned out with sticks of all sizes, and other defensive weapons, yet that the monkeys had carried off a child, taking it into the jungle where its parents and neighbours were afraid to follow the track. $\mathrm{He}$ ended his story by entreating the English Sahib to join the party that was going out to-day to find the poor child, and to punish the offenders; he urged his request, pleading so earnestly, that I had not the heart to refuse him, and at last consented, though, I must say, the idea of shooting monkeys was most repulsive to my feelings.

I once shot one, and shall never forget my pain at seeing the poor little fellow sitting up in the tree, putting his little hand to his side, which had been wounded, 
and trying to staunch the blood; then he would look at his bloody hand, moaning all the time so piteously that I felt miserable all the day after it. I should mention that the poor little monkey dropped from the tree very soon, and, on my going up, I found him quite dead, and was very glad to know that he was out of his pain and misery. This pitiful little scene gave me such a thorough disgust to monkey shooting that I did not think I could ever fire at one again; but I felt justified in the present case, as it was to restore a lost child to its sorrowing parents.

My tent was put up, and, when I had finished my breakfast, had taken my bath, and was enjoying my cheroot, I saw a number of villagers approaching, headed by my friend of the morning; they were all armed with thick sticks, hoes, and every 
conceivable weapon, and some few old guns were carried among the party; the guns I thought would prove much more formidable to us than to the monkeys.

After a brief parley, and after I had given instructions to the Bengalee to follow with my gun, and to bring plenty of powder and shot, off we started, heading in the direction of the jungle. We went very slowly as several old people accompanied our party, and I observed my fat friend of the morning did not get on so fast without his half-starved pony. After a time we began to see monkeys ahead, scuttling off before us ; they were few in number, but I noticed they were large and fierce looking. As we proceeded slowly the numbers increased, and soon they seemed to be pouring in from all directions; they ascended all the trees in our route, and the chattering and 
screaming they kept up was deafening. They would also spring down to the lower branches of the trees and show their powerful teeth in a most formidable manner; their eyes, at the same time, darting fire, and all the hair on their backs standing erect with fury and excitement. Their numbers continued to increase, and I proposed beginning offensive operations at once, but, on turning to ask why we delayed, I observed all the men were pale with terror, and they were all shaking and their teeth chattering with fright.

The monkeys, who by this time, had received fresh reinforcements, were now to be counted by thousands, and some of the larger and older ones were armed with thick branches from the trees. Our little army now talked of retreating, and, seeing the panic they were in, I prepared to take 
the lead. Calling on them to follow, I stepped forward, and was looking about to see which monkey should be my first victim, when, all at once, I felt myself covered from head to foot with them; there must have been about a dozen upon me when I called out for assistance, but, on looking for my party, I saw them some distance off, making for home as fast as their legs would carry them, leaving me to my fate without the slightest compunction. My assailants were not inactive all this time; they were biting me in the most cruel manner (and let me here assure my readers that monkeys can bite); it appeared to me that each one was, independently, trying to take the largest mouthful he could get out of my unfortunate body.

The agony I endured is not to be 
described. In my despair and anguish I dropped my hand to my side, and it was seized in an instant by the powerful jaws of one of the largest of the brutes, who bit me to the very bone. This was the climax of of my sufferings, and I sank on the ground in a dead faint. How long. I lay insensible I have no idea, but when I came to myself, the monkeys were still around me in numbers, and some were sitting upon me; all the trees in my vicinity were crowded with them, chattering at the top of their voices, and evidently very proud of the victory they had obtained. I was here startled by a loud report close to my ear, and, on looking round, I discovered that my gun had exploded. It appeared that when my hand fell to my side in my agony, my gun had dropped out of my paralysed fingers ; 
it had both barrels cocked, and now at the moment of my recovering my senses, one of the tribe, taking it up to examine it with accustomed curiosity, pulled one of the triggers, and hence the explosion which might have blown my head off. The effect of this was most startling, and, under God's blessing, was the means of saving my life, for every monkey within sight or hearing took to his heels in terrible fear, and, in an incredibly short time there was not one to be seen.

I staggered to my legs, and seeing the coast clear, I seized my gun and retraced my steps at my best pace. I had not gone far when I met all my own establishment, and they raised a shout of joy at seeing me safe, as they were seriously alarmed at finding the party had returned without me; and the runaways had given 
a very alarming account of the attitude of the monkeys when they left the place. I now stopped to examine the bites I had received; I was covered with blood, which was still flowing from many of my wounds ; there was hardly a bit of my body that did not contain a bite-the depth and length depending upon the size and strength of the jaws of the animal who had inflicted it, as they were all equally anxious to punish me to the very fullest extent of their power; and, if it had not been for the accidental discharge of my gun, I should not now be alive to relate the adventure.

I was thankful for my escape, but deeply regretted that I had been unable to find any traces of the unfortunate child, whose loss had been the cause of our entering the haunts of these dangerous 
monkeys; and I was so angry with the cowardly party I had intended to assist, that it was well for them-one and allthat I met none of them before quitting the place. I need not say they kept clear of me till they knew I was too far away to revenge myself. I spent the rest of that day in bed, my servant bringing in an old woman who washed my wounds with some decoction of herbs, and put on some plaster, and when I awoke in the morning I was nearly all right again, only for the excessive soreness all over me from the bites; but I vowed it would be the last time I would trust to the courage of native villagers in another case where pluck was required.

The next morning I started off at my usual hour, feeling wonderfully little ill effects from the mauling I had received 
the previous day; and I give all the credit to the skill and judgment displayed by the old woman who doctored me over night. Our camp this day was near some lakes, so I determined to try and get a few wild duck or teal. I was most successful and brought in a great many birds; the teal were so numerous that I sometimes knocked down as many as eight or ten at a shot, so that both my servants and myself had a thorough feast of them. The next day I was quite recovered from my monkey adventure, and found my appetite returned in full force. After I had finished my breakfast I had a mat brought out and spread under one of the magnificent trees among which my tent was pitched. I threw myself upon it and then lighted a cheroot and I don't think I ever enjoyed anything more than that smoking; I was 
fanned by a nice cool breeze, the shade of the foliage kept off the rays of the sun, and my ride of twenty miles before breakfast had just sufficiently fatigued me to enable me thoroughly to enjoy the complete repose of my present position. I lay thus till tiffin was announced, and by that time I had an excellent appetite and was as " sharp set" as if I had only partaken of a very moderate breakfast. I believe if a hearty man is starved for a time, he subsists on the inner fat of his constitution, and the first good living he enjoys, the debt is paid back in full; hence my extraordinary appetite, which really seemed to be quite taking the form of a disease. I felt very glad I was not a member of the mess just then, or I should have had but little peace; my friends would have made up mess parties and invited strangers on purpose to 
see me eat my dinner-the "lion " of the camp for the time being-and then, when the novelty was over, fellows would have got disgusted, and probably christened me the boa constrictor-not a pleasant appellation to stick to one, perhaps, for life! So, altogether, my appetite set me thinking; and, as it seemed to me that hard work only served to increase it, I determined to take things very easily, and march slowly instead of doing twenty miles in the day, to do only ten, halting every Sunday.

This suddenly reminded me that I did not know the day of the week, much less the day of the month-and, in fact, I had no idea what month it was. I am sure the fearful blow I got on the head had impaired my recollection, for I was frequently forgetting things which occurred onlv the day before, and I had not nearly 
the same amount of energy I possessed formerly. I felt as if I had got some twenty years older in the last month or two, and at times could not imagine I was the same fellow with the same tastes I had only so lately. A few months since, if I had bought a new horse or pony, I should have been on his back almost day and night; now I had two, and I seldom looked at them. This train of thought roused me to take a look how the grey Arab horse was getting on, so on my way to my tent, I told the sais to take off his kaprá, and, on this being done, I observed a very great change for the better. $\mathrm{He}$ was filling out fast, and his back was no longer disgusting to look at; the sores appeared to be drying up under the judicious treatment of the attentive horsekeeper; his ewe neck and ungainly head 
were less apparent, and I hoped in a week or two he would be fit to ride. The native who had found him, must have turned him out to graze in the jungle, and as he had not been used to foraging for himself, he would have died in another week or so if I had not, fortunately for him, come across his path. The sais grinned his delight when I expressed my approbation at the altered appearance of the horse, and told me he was giving him coarse, soft sugar, and that was the chief cause of his picking up so rapidly.

I also had a look at the tattú, who was eating his grain with wonderful satisfaction; he was less puffy and looked all the better for it. I thought what a prize he would be to the proprietor of a circus at home, for he is a nice tempered little fellow, and one that would soon learn any 
tricks if he were taught. The sais let him loose when I called him, and he always trotted up for his bit of bread and a piece of sugar, of which he was remarkably fond. He was a very cheap pony, and I am quite sure worth three or four hundred rupees; he was so strong and sure footed that he could carry any heavy weight safely, and a pony that can do this is very scarce in India, as so many persons are on the look out for such.

The following morning I was off soon after daylight, and arrived at my tent when the sun became hot, but we always managed to pitch our tents in a tope of trees, so that we might get all the cool shade and fresh air that were to be had. It was only during the hot winds that we tried to shut out the air; and, even then, the burning blast which blows without 
intermission all day we would turn to account by putting up thick kaskas screens ; and, by constantly keeping these wet, the good soaking of water cools the hot air that blows through them, and thus the house, or tent, becomes nice and fresh. I do not know of any people who study their comfort so much as the European residents of India; they certainly understand the method of making themselves comfortable, and it is absolutely necessary for their health that they should do so.

I had just taken up my cheroot preparatory to smoking it after breakfast, when one of my attendants entered the tent to say that some jugglers were waiting to exhibit their skill before the great English sahib, and, as I was heartily tired of my own reflections, I desired they might be shewn in. The party consisted of three 
or four men and a girl, and the only adjuncts they appeared to have with them were one or two pretty large baskets and some kaprá, or dirty white cloth, which I suppose was to be held up for the purpose of concealment; for, like their English brethren, they do not wish their audience to see more than they intend. I seated myself under a tree at their request, and let them arrange my chair themselves, so that I should not spoil the entertainment by being improperly placed. As soon as I was seated, the whole company, including the tamtam wallah (the man who beats a kind of native drum) came forward in a body and salaamed to me, while the eldest of the party, quite a patriarchal looking fellow, commenced a long address in Hindostanee, which, unhappily for me,

I could not half understand, and I daresay 
I missed a good deal by not having a thorough knowledge of the language.

The performance then commenced, and, though I had heard a great deal of the dexterity and cleverness of these itinerant jugglers, I must say I was agreeably surprised. They began by planting a mango seed in the ground, then they watered the place and covered it up for about five minutes with a wall of cotton round it ; on the screen being removed, there appeared a little plant about three inches high: then more watering and fanning, when it was again screened, and after another interval of five minutes it was shewn as a little tree, about a foot high, with a beautiful large mango, quite ripe, growing upon it; this was pulled and presented to the English sahib. Then there was jumping through tight hoops of rope, through which the per- 
former first proved to us that he had the greatest difficulty in squeezing himself; he would then retire a few yards, and, on the hoop being held up by another man, he would make a little run and go through it with ease, head foremost. One of the men threw a hard cocoa nut high into the air, and catching it on the top of his bare head it was smashed to pieces, the milk running down his face; this cocoa nut was first handed to me to inspect, that I might know it had not been tampered with. The girl now came forward and placed a small silver coin on the ground; then placing herself with her back to it, and, doubtless, judging her distance, she bent herself backward, arching her slender body until her face reached the coin, which she picked up with her eyelid. This wonderful feat led one to question whether she had any 
bones at all in her body. There were many other tricks which I have now forgotten, but I know they amused me very much at the time, and helped to pass a pleasant hour or two.

The head man now came up and salaamed to announce to me that the entertainment was over, when I desired my Bengalee to give them a few rupees, with which they went off quite satisfied. It was not an expensive entertainment for my little establishment, and all their wives and children crowded round also, enjoying it as much as I did. All the afternoon I saw my servants, and all the little offsprings in the shape of ebony youngsters, practising the jumping through a tight hoop, but I don't think they were very successful excepting in getting some awful croppers now and then. 
After tiffin, when I was taking my afternoon siesta, an attendant announced a man who wished to speak to me, and on my desiring him to be admitted, he told me he had been sent by the English political agent to search for me everywhere, and to find out what had become of me. He said he had been in the two villages in which I had been imprisoned, and that the people in both villages had been greatly distressed at finding I had left the comfortable room they had prepared for me, as they had intended to forward me on, in all honour and state, to the head quarters of the English army, but that I had evidently taken a dislike to them, which they extremely regretted, and I had gone off without taking leave of any of them. They felt disappointed at this, as they had a handsome present, 
which they intended giving me; but as I did not take it at that time, perhaps I would be pleased to accept it now as a token of their esteem and goodwill. The messenger hinted that the "present" consisted of five hundred rupees (fifty pounds) in gold, and he said how gratified they would all feel if the English sahib would condescend to accept this small offering of their goodwill and respect. From the hearty manner in which this fellow urged their cause, I could see he had been well bribed; he never once alluded to the cruel manner in which I had been treated in both villages, nor did he say a word about my being tried and twice condemned to death.

I told him I would have nothing to do with them, or with their present, and that I would report their infamous conduct to 
the political agent the very first opportunity I had. I also sternly asked this fellow what he had to do with it, and how it was that they had induced him to take so much interest in my accepting their paltry . present. He seemed confounded at my having detected his little game, and retired quite abashed and humbled. The next morning I overtook him on the march, and he attracted my attention by the lowness of salaam and the abject respect with which he treated me. $\mathrm{He}$ begged I would send by him a chit, or note, to the political agent, who was travelling with our army, which he informed me was some two hundred miles ahead of me: he told me all was satisfactorily arranged with the Nepaulese, and that I should be treated with the greatest respect and consideration in all 
villages en route. He then gave me his advice not to pay for anything, and said he heard with some surprise that I had been doing so, and he thought it a very bad custom. This man evidently feathered his nest well on all occasions, for, as a rule, these creatures, who are attached to civilians to perform the humbler duties and to do all the dirty work, fleece the poor natives shamefully, and hold up the name of their master over them as a whip to make them disgorge their hard earned savings. This used to be the common practice some years ago, but I do not know whether it still continues.

I got so tired of my own thoughts and my own company that I determined to push on as rapidly as I could, in order to overtake the column, but it would take double marches for a long time, and thus 
would soon knock up the servants, also the bullocks and horses; however, I resolved to try it for a few days at any rate, so I did a march in the morning and and also one in the evening, and by this means we were getting over the ground rapidly. I took another look one day at the old grey Arab, and was astonished to see how steadily he continued to improve; his back was quite well, and he looked so fat and full of vigour, that I decided to have my saddle fitted on his back, and ride him the following morning. A native saddler was sent for at once, and he altered it to his shape, for a saddle intended for a pony will not fit a large horse.

The following morning I mounted the grey, and was delighted with the elastic, firm manner in which he put his foot to 
the ground, and his paces were so light and springy that it was a real pleasure to ride him; though very quiet and gentle, like all Arabs, he was full of life and spirit, and I do not remember ever enjoying a ride of ten miles so much. After we had a good gallop across the plain, we came to a pretty little hedge about four feet high, at which I put him, and, to my astonishment, he cleared it like an old hunter; generally, the Arab horse is not given to jumping, as, in his own country, there are no fences of any description, so he must of course be taught to jump, as it does not come naturally to him.

When I resigned the horse at the end of the march to the care of the sais, he was greatly pleased to hear how much I liked my new acquisition; I praised the care he had bestowed on his charge, and, 
to wind up, more to his satisfaction, I gave him a rupee as bakhshish (a present) which he thought much more of than all the praise I could bestow upon him. I told him I should ride the horse every morning, and allowed a servant to have a mount on the tattú; this arrangement gave general satisfaction, and we now only thought about getting settled in cantonments. I was now within a week's march of the desired goal, when I ascertained that a few days would bring me into the vicinity of some good shooting, so I sent a chit by a coolie (a porter) into the station in which the troops were quartered, to ask three or four of my brother subs to join me over night and have a good day's shooting, naming the spot where I should pitch my tent. I promised to secure beaters, also a shikári-a sportsman who knows where all 
the game is to be found; the shikari is also a good hand at tracking wild animals, therefore he is a very important personage at a gathering of this sort.

I received a reply in due time by the messenger, accepting my invitation,- but first congratulating me on what my friends were pleased to call my resurrection, as one of the soldiers swore he had seen me struck down dead; he had stooped over me for a minute, and, seeing no sign of life whatever, he was obliged to hurry off to save his own, and I am confident the poor fellow had only stated what he firmly believed to be true. This note reached me on the morning of the day on which I arrived at the appointed place, and I did not delay in making all the arrangements necessary for our shooting the following morning. 
In the evening my friends arrived, and it did my heart good to see them again, and to hear their jolly, cheerful welcome back to the corps. They had believed me to be dead, and had all mourned my loss as a dear brother, and the reaction when they had ocular demonstration that I was really alive, was most flattering to me; they could not make enough of me, and were never tired of hearing my adventures; the scenes in the tiger jungle seemed to afford them never failing interest and pleasure, and my descriptions of my girl companion and myself going to roost in the trees at night would set them off in a roar of delight that I thought would never cease. Then, when I told them of the trial and sentence of execution, which even now makes me sick at heart, I was quite overcome; and the excitement at 
seeing their dear faces again had brought a reaction that $I$ tumbled off my chair in a dead faint, much to their dismay and consternation. They ran about, not knowing what to do, till my Bengalee, hearing the row, came rushing in, carried me into the air and sprinkled water over my face, and in time I came round, much to the relief of my kind visitors; but I knew I must give up the idea of shooting in the morning, as I was so weak I could hardly walk without assistance, and I felt so utterly done that there was nothing for it but to lie quietly on my bed.

The evening was so fine that I had the dinner laid out under a tree, where my friends conversed in quiet tones so that I might not be disturbed by their talking. I felt very ill and thought I was laid up, and in for another attack: as the night 
progressed I became gradually worse, and by the morning was in a highly dangerous fever. When my guests got up at daylight they were seriously alarmed about me, so much so, that all idea of shooting was discarded, and it was decided that one should remain with me while the other three rode back to camp to send medical aid with the least possible delay. As soon as they had swallowed a cup of coffee they were off; and, as one of their tattus had not recovered the journey of the previous day, mine was substituted, and off he rattled with the rest.

By this time I was perfectly unconscious, and remained so until our assistant surgeon made his appearance. He did not like the aspect of my disease, and gave orders that I should be put into the hospital doolie which he had brought with 
him, and be carried into camp as soon as possible. Before I started he administered some cooling lotion, and with his own hands cut off all my fine thick hair, of which I had been justly proud. He was only just in time, for I. afterwards found out that if this malignant fever had not been checked at once, and had he not seen me when he did, his opinion was that no human skill could have availed me. He rode his pony alongside my doolie all that day and night, frequently administering sedatives and applying cool bandages to rny burning head; no brother could have been kinder, or have shown more devotion than he did to me, and the recollection of his medical knowledge, and great, disinterested attention, fills my heart even now with gratitude to him, for, under God's blessing, he saved my life. 
When we arrived in cantonments I was carried at once to the assistant surgeon's bungalow, put into a bed, and ice applied to my head; this was done even before he had time to summon additional medical advice. I believe all the doctors who saw me the following morning were of opinion that it was a very bad case; and I afterwards ascertained that they attributed it all mainly to the deadly and crushing blow I had received in battle, and the want of medical treatment at the time, but it was too late to regret that now. My being, carried into the station ill and insensible, combined with the fact of my having been a prisoner and condemned to death, to say nothing of my hairbreadth escapes, created quite a sensation in cantonments, and little else was thought of or talked about for days. 
In the meantime, thanks to my excellent constitution and the highly skilful manner in which I was treated, I turned the corner and began very slowly to recover. I remained for days in a dazed state, and my head was constantly aching; everything seemed dark and dismal, and my dreams and thoughts were always of the most gloomy character. This went on for weeks, but, at last, a little light began to penetrate the darkness and gloom of my mind, and then there came a decided change for the better; I gradually resumed my full consciousness and comprehended that I had been very dangerously ill. I was so weak that I could not stand, and, as to raising hand or foot, you might almost as well have invited me to accompany a bird in its flight through the air. I cannot imagine any- 
thing more miserable than this total prostration of mind and body, and should be sorry to see my worst enemy reduced to such a state of weakness. My recovery was most tardy, and I lay for a long time between life and death, one day slightly better and perhaps the next a little worse: my case sadly puzzled my kind medical friends, and I believe they attributed my slow amendment to the starvation, anxiety and fatigue I had undergone, and nothing now but the remains of my once excellent constitution gave hope of a permanent recovery. 


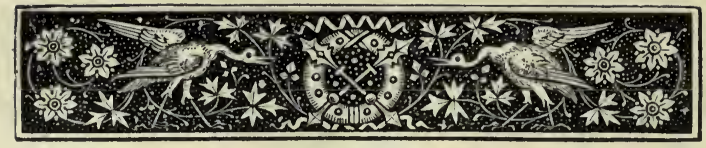

CHAPTER VI.

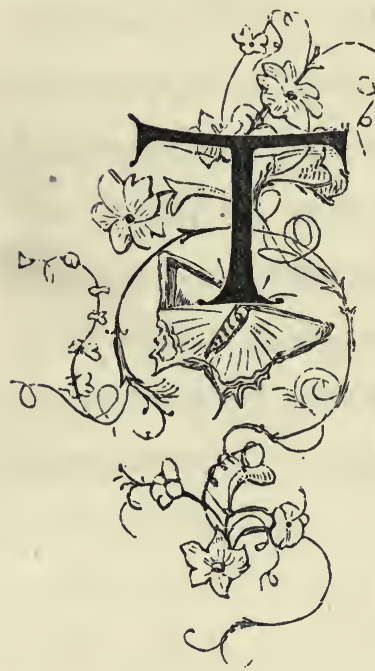

$\mathrm{HE}$ doctors now decided unanimously that I must have complete change of air and scene, but where to send me in my weak and helpless state was a perplexing question. There was no doubt about England being the chosen place if it had not been for the long land journey to the port of embarcation; but this distance rendering it impracticable for me to 
attempt it, that idea was given up, greatly to my peace of mind, as I had no desire to be invalided for a long time away from my regiment, and Landour, in theHimalaya Hills, was finally the place selected. There was a medical board ordered to assemble at the doctor's bungalow where there was more pulse feeling, and tongue examination, after which I was informed that I was to go to Landour on six months' sick certificate, and the president of the board, kindly told me to write to him at the expiration of that time if I did not feel quite strong and hearty, in which case I need not think of returning to the plains, as he would procure me another six months.

They were so determined that I should make a start of it without delay, that I was hurried off that very night in a palanquin 
for the hills, and by morning I had travelled some forty miles. I remained at the government bungalow all the day and had some tea and toast, which was all I could take; and, when it became cool I was assisted into my palanquin, my bearers trudging off with me as before. In the morning we had done another forty miles, and I found myself in a similar 1bungalow, with the same tea and toast, and it appeared to me the very same rhitmatgar (attendant) in charge of the bungalow as on the previous day; the life was indeed monotonous.

On the evening of the third day I found myself at the foot of the hills, gazing up with astonishment and awe at the stupendous mountains before me; to add to their beauty they were clothed with lovely foliage from their base nearly to 
their tops which were covered with eternal snow, the whiteness and purity of which, standing out against the deep blue sky, formed a most splendid contrast. I do not think I shall ever forget the wild and wonderful magnificence of this scene-a scene that I fancy stands unrivalled in the world for grandeur and perfect beauty. It made a heavenly impression on my mind at the time, and it seemed to lift my thoughts above the world. I think when the body is very weak and the soul half way, as it were, and hovering between the two worlds, our thoughts are much more pure and heavenly than when in robust health : my belief is, that before our heavenly Father takes us to himself, our ideas-I mean our earthly ones-are softened and purified, and we see things, which before were incomprehensible to us, much more clearly, and 
are able to understand more about the heavenly home which we seem to be rapidly nearing. I know this was my idea at the time, and I have had no reason to change it since.

We stopped at Dhera-Doon, at the foot of the hills, and the next morning ascended in a curious looking conveyance; it seemed like the small body of a gig placed on a long pole which went under and supported it; this pole rested upon the shoulders of four men-two in front and two behind-and this is the way I ascended the world-renowned Himalayas. I forget how long I was ascending, but remember being struck with the great increase of cold; the higher we proceeded, the more inclined I felt to add warm wraps, until every article of clothing I had was used somewhere about me. I cannot tell what 
I should have done if my landlady, at the foot of the hills, had not kindly lent me a warm rug or two, which were to be returned by the bearers when they had deposited me safely at Landour. I arrived there in due time, and was recommended to some rooms kept by a Frenchman; fortunately they were unoccupied, were comfortably furnished, and I engaged them at once. I felt the climate here almost too cold for me, and ordered a wood fire to be lighted at once in my sitting room; when that was done I sat down opposite to it in order to give myself a good toasting, when I began gradually to feel more comfortable.

My attendants not having arrived, the butler of the hotel came to ask what I would have for dinner; but, from his account, there was not a great variety of 
food, the only thing I could hear of, being a neck of mutton, which would make cutlets, and he said he might be able to procure a small chicken in the bazaar, for curry. He told me beef was very difficult to get, for when a bullock was killed, it was all bespoke long before, and it was impossible to procure a small joint. So the question of beef was finally settled. He thought, however, he might get me a duck on the morrow, but he was not so sure about that. I found I might make my mind easy on the subject of food, as mutton was always to be had in the bazaar, and no one could starve with good roast and boiled mutton in abundance. The butler retired, and I was again left to my reflections and to my comfortable wood fire, which I continued to sit opposite to while I meditated upon the 
wonderfully rapid vicissitudes I had been subject to in so short a period.

I leaned back in my easy chair, half asleep and half awake, for, in my weak state, and after the heat of the cantonments, the exertion of travelling in a palanquin along the dusty roads had tired me sorely; but, now that I was rested and refreshed, I felt considerably better, and the pure, fresh mountain air, cooled by passing over the perpetual snow, came to me as a precious gift from heaven, to restore me to that health and manliness which would enable me to follow out the profession I had adopted, and in which my whole soul was wrapped up. A soldier's life was the only life I cared for; from my earliest recollection, my chief ambition was to be an officer, and, now that my feet were resting well on the 
ladder, it would have been too hard if I had been obliged to leave on account of bad health or delicate constitution. I had felt very anxious when the doctors not only hinted, but spoke very plainly their opinion that unless there was a great improvement in my health, and unless my constitution gained strength I should not be wise to continue in the army, a life that would constantly expose me to the vicissitudes of various climates, with perhaps a good deal of nightwork and exposure to rain and dampness; but, I trusted, with God's blessing, the bracing air of the Himalaya mountains would renovate me speedily.

I sent a servant to the library to get a few amusing books, for I knew the mind was as much impaired as the body, and thought if I could find some amusement 
in the way of light reading it would help me through my imprisonment in the house, for taking walking exercise was still out of the question. The roads at Landour are very steep, so that whichever way you turn your steps it is either an ascent or a descent-most trying to an invalid. While sitting in front of the fire, my reflections at last assumed a more cheerful form than at first, and I reasoned with myself on the folly of being lowspirited and depressed; and assured myself that if I wished to be strong and healthy, the way to become so was to keep up my spirits and make the best of everything, putting the most favourable construction upon all that happened to me; by this means I should always be able to swim on the surface, instead of grovelling at the bottom in all the slime 
and mud. I felt much happier after I had come to my senses; allowances, after all, must be made for a fellow so ill and worn out as I was, for I had not yet had time to recover from the horrors and dismal effects of my never-to-be-forgotten escapes.

A knock now came at my door, and a slight, pale looking young man entered the room to call upon me. At the first glance I knew he also had been sent to the hills on medical certificate, for there is no mistaking the pallor of the cheek and the extreme emaciation of the body, to be seen at a glance by a brother sufferer. He told me his name was Smith, and said he was a cornet in the first Light Cavalry; that he was just recovering from a smart attack of jungle fever, and had been sent up from the plains on six months' sick leave, with the advice that if not perfectly 
cured he was to apply for six months more: in fact, just my case, and I dare say we should have matched each other splendidly, and run in a curricle together. I was glad to find Smith was staying at the same hotel-indeed our rooms were adjoining; so we agreed to dine together, and be in each others' company as much as possible, as we found, on comparing notes, we were both as miserable as we could well be. We spent the evening together, and were much amused, when his dinner was brought in along with mine, to find that we had both mutton cutlets and curry and rice. In the course of the evening, on our mutually liking each other, we determined to establish a little joint mess and to appoint his rhitmatgar our khansumar, or messman; this arrangement added much to our 
comfort and considerably diminished the expense to each of us.

From this time I began rapidly to improve in mental as well as bodily health, and I was pleased to see a similar improvement in my new chum, who, however, I think passed me a little in the race for life we were running. I did not, for a long while, get over the dreadful dreams I had frequently at night. I used to dream that the awful fellow who first carried me away after I had been wounded, was shaking me, telling me to get up as my last hour was come; I used to fancy he was looking straight into my eyes on these occasions, and I saw his firm mouth compressed and his sinister glances, as clearly as I had seen him in reality when we exchanged looks for the first time, as he threw me across his broad shoulders before carry- 
ing me off to prison, and, as he thought, to death. I would then start up in terror to find myself bathed in cold perspiration, and this would occur two or three times a week. I told my friend Smith about it, and he did what he could for me by keeping me amused till the small hours. We used to play ecarté, back-gammon, or any thing else to make the night pass quickly, and I found that by going to bed very late that I had not these painful dreams, and having once discovered the remedy, I did not fail to put it into practice.

Sometimes my chum would get a return of his fever, when he would have to go to bed at nine or ten o'clock, on which occasions I used to sit in my arm chair in front of the fire all night, not going to bed till the servants were up in the morning; and at their work dusting and clean- 
ing out our rooms. I fancy they thought I was a little out of my mind for pursuing so singular a course, but if they had experienced my frights in the night they would only have been too happy to follow my example. We both steadily progressed in health and strength, and, by the time we had been two months in the hills, could walk with the aid of our sticks a mile out, when we could sit down and rest awhile, and leisurely stroll home. They were gala days to us when we were able to take these quiet constitutionals, for we were often prevented going out on account of the frequent thunder storms, which generally brought on rain, lasting several days; but when we did get a fine, sunny day, we made the most of it, and on our return from our walk, would throw ourselves on the mutton 
cutlets and chicken curry with fierce avidity.

Becoming so strong and vigorous we talked of a little shooting excursion, but it would have to come off some time hence, for as yet, neither of us could have walked five miles if our lives had depended upon it; but we did not think it improbable that we might be able to start in a month, and it would take us very nearly that time to prepare ourselves for the excursion. I had to write for my gun and also for the piebald pony to be sent up, with several of my servants, but some of them had to be discharged. Altogether I made my establishment into a working one, and I asked a friend, who was one of my sporting chums, to procure me three or four good dogs, which were to be started off to me at once. Some of these common, half- 
bred dogs are excellent ones to find game; and, though they will not stand when they find it, still by following them up closely you may get wonderfully good partridge and quail shooting over them. I ordered also one of the strong Persian greyhounds, which are as fleet as our greyhounds at home, but a much more powerful animal to pull down a wounded deer. With this lot, in addition to the dogs Smith expected, we thought we should have very decent sport, and were not far wrong in our expectations. I asked a friend, in cantonments, if he would accept the loan of the Arab horse till I returned, which I did not see any prospect of doing for at least, some months, as we both intended to apply for the extra six months which we had the option of taking. 
Several days must elapse before we could receive our guns, dogs, and ponies up from the plains, so we looked out for a shikari to accompany us; and, from the cheering accounts this man gave of the quantity of large game lying close to where we were staying, and also hearing that they were seldom shot or disturbed, we hoped to make such a bag as seldom had been heard of by sportsmen in the Himalaya mountains. We left the shikári to engage the coolies and beaters, and, in addition to these we required several coolies to carry our tents, bedding, provisions, and wines; though we did not intend to take a large supply of the latter article, still we were both invalids and absolutely required our wine. I used to take half a dozen glasses of good old port every day from which I derived the 
greatest benefit; Smith was also ordered to drink port, so we were obliged to take a fair quantity between us.

All our luggage was so arranged that every box, or parcel, was to be a load for a coolie, and by this means we saved a great deal of trouble and breakage : every parcel, or load, is carried on the head, so that the coolies can ascend the steepest hills, and also descend them with perfect confidence and safety. We heard a good account of our shikári and we were much pleased with the men he had engaged, all of whom were under him, so that we had no occasion ever to speak to one of them; we were to give the shikári a specified sum of money for the journey, which was to last so many weeks, and when we returned he was to receive the balance of his hire, to take himself and his coolies off, 
and we were to have no further trouble. He was to provide food for himself and all his people, so we had only to cater for ourselves and our personal attendants, and we never had reason to regret our arrangement with this hardy mountaineer.

Ascertaining that my pony would be of very little use in the mountains, I decided not to take him with me, but he was very handy to ride about Landour. Before starting on this shooting expedition I sold him one day to a colonel of artillery who had often admired him, and he had asked me if I would sell him, as he was cal culated to carry a much heavier fellow than I was. I now offered him to the colonel for four hundred rupees (forty pounds), for which amount he gave me a cheque without demur, so the piebald pony and his master parted company; 
and I may add that I frequently saw him carrying his new owner, who weighed sixteen stone, and who told me that he would not take a thousand rupees for his bargain; thus we were mutually satisfied. At last the happy day arrived when we were to make our grand start and I could hardly sleep at night for thinking over the pleasures of the morrow. And here I may mention that I never now suffered from those dreadful dreams which had so long distressed me, and my remedy therefore was a complete success.

At day break the shikári called us, and when we turned out after breakfast the little compound was filled to over-flowing with the number of coolies we required. I had previously labelled every load so that we might know at a glance what each contained;' and I must take this oppor- 
tunity of impressing my young sporting friends with the importance of adopting this plan if the loads are to be carried on men's backs. We met a party of three officers, afterwards, who were also on a shooting expedition, and they were always in a state of confusion; if a little powder or a box of caps werewanted, then the whole eighteen loads would have to be opened, and most probably the required article would be found in the last load. I need not suggest that it is equally necessary to replace the packet in the same load when it is done with.

It took us some time to load all the men and get them off, but our head man had had much experience in this sort of travelling; he gave each coolie and his parcel a number, telling the man that if he lost or mislaid his load he would get 
a good hiding and have his talab cut (which means his pay deducted), and, as most of them had been on similar expeditions before with him, I did not anticipate losing anything, nor did we lose a single article during the expedition. We got off just at daylight, and for a good while struggled on through a thick fog, but our shikari assured us the fog would lift as the sun rose, and he was right, for it turned out a heavenly day; and, as we ascended to the top of a hill just above the station, the view was most enchanting. We now entered some scrubby bush composed of awarf oaks and clematis prettily grouped together; this was very pleasing to the eye, but we had other business on hand that required all our attention, and we pushed on. The dogs now beating very closely I ran up just in time for a double 
shot at a covey of partridge which rose as I got near, and I had the satisfaction of seeing a brace and a half picked up. There were great grunts of approbation from the coolies at witnessing our first success, and they seemed to step out more lightly when they saw that one of the party could kill.

We now descended a steep hill, but the carriers took off their loads, and sat down to watch us beat up the valley with as keen an interest as English beaters would have displayed. The first thing that showed itself was a splendid cheetah; he got up in front of Smith, who had two bangs at him, but he went off apparently untouched. I thought it was rather lucky for Smith that he did not hit, for the cheetah would have turned on him, in all probability, and given him a severe mang- 
ling, though I must own I envied the animal the splendid skin with which he walked off. We now got plenty of shots, and our stock of game increased satisfactorily, but we ought to have bagged more than we did: whether it was nervousness or the effects of the fever I cannot say, but my companion missed some very easy shots; I fancy it was from firing too soon. If sportsmen would only allow their game to get away some forty yards before firing they would have a very much greater chance of killing, for the shot then expands and covers a greater radiance; whereas, firing at a bird the moment he is on the wing is very imprudent, for the shot has not time to separate, but goes like a bullet, and if it does hit the object it almost blows it to pieces; after all, perhaps this has one 
advantage as it either kills the bird stone dead or misses it altogether.

We still proceed, and presently a large black bear came out of the jungle to see what all this shouting and knocking the trees with sticks meant. He did not appear the least frightened, but gazed on us with stupid curiosity: he was within easy shot of me, so I promptly popped in a bullet just behind the left shoulder, and, before he could turn, I had planted another in his skull; but I fancy the second bullet glanced off the bone, for in afterwards skinning him, we could not find it. On receiving this unexpected reception his whole appearance changed in a second; from being a sleepy, good natured looking animal, he was suddenly transformed into a demon; his eyes, which before had a mild expression, now 
appeared bloodshot, and they were flashing with furious rage. He came at me in a lumbering canter, but, having a fresh double barrelled gun just put into my hand, I cocked it and calmly awaited his approach. When he got within a few paces of me, he stopped and got up on his hind legs, intending to hug me, and at the same time to tear me to pieces with his formidable hind claws; but I was equal to the occasion, for as soon as he was in this position, he disclosed a white spot on his chest which is just over the heart; and, without further delay, I popped in another bullet there and had the great satisfaction of seeing him roll over stone dead.

He was a magnificent specimen, and the shikári assured me he had never met with a finer bear. Half a dozen coolies now set 
to work to skin him, an operation which they completed in an incredibly short space of time; the flesh was then cut into twenty pound pieces which were fastened on the top of the carriers' loads, and the men were all delighted at the prospect of such a good meal, and I believe they prefer bears' meat to either beef or mutton. We had some of the flesh dressed for our own dinner in the evening. I can hardly describe its flavour, as it savoured both of pork and of beef, but we found it deliciously tender. We were exceedingly tired and done up, but felt rather proud of our first days' work; and, on counting our game, we found we had got twenty brace of partridge, three hares, five deer and the renowned bear.

We did not waste much time over our port wine that evening; indeed Smith was 
asleep before the cloth was removed, and all my efforts to awake him were ineffectual, so I directed his servants to take off his necktie and boots and place him on his bed, which was done, and I rather envied him the next morning when I saw him so well forward in dressing.

We started again at daylight, and this day's sport was better, which we attributed to our being further away from cantonments. We did not begin shooting very early as we had to ascend a steep mountain which quite knocked up the poor coolies, but, we cheeredthem with a promise that we would endeavour to procure them another bear; in this, however, we failed, Smith had an encounter with one, but let him escape in a clumsy manner. He had rather a narrow escape himself, for, when the bear charged him 
his attendant ran off, (probably not having much confidence in his master's shooting powers) and the bear might have injured poor Smith very severely if the shikari had not come to his assistance with his hunting spear-without which he never travelled, and thus he was the means of saving Smith's life. One of the men ran up to tell me of this adventure, but I heard a more full account of it afterwards from the shikári. It appears great folly for any one to go after dangerous game, such as tiger and bear, unless he is firm in his nerves and an undeniable shot; otherwise his servants will not stick to him if he gets into trouble, but will make off with his spare gun at the shortest notice. But I am digressing and must hark back.

While this encounter with the bear was going on, I had some very pretty quail 
shooting all to myself in a little barley field; the whole patch was not a hundred yards square, but it was full of birds, and I am afraid to say how many I bagged there. When I had cleared it out, I went into another cornfield similar in size to the one in which I had found such good sport. I had not been long beating it when I observed a large black lump of something-I could not tell what,-lying at my feet; while I was examining this, it suddenly jumped on its legs and then I discovered it was a great black boar, who, without a moment's delay, charged at me, and I do not know what would have happened to me if I had not had the presence of mind to turn the gun downward and fire at the instant, when I was fortunate enough to send the whole charge into his eye, and he tumbled 
heavily forward, falling dead at my feet,or, I should have said, on my feet, which knocked me over; and, having thus felt something of his weight, I did not require to be told that he was " a splendid fellow and fat as a pig," which was the general remark when my friends came up later to see him. I was amused at the sereams of delight from the coolies, who were perched on the hill above me, at the prospect of another great meat dinner; they sang and danced with pleasure, not altogether at the prospect of the feast, but also, I belíeve at my skill and success. If I had missed the boar it would have been a serious matter, for in passing me, he would, without doubt, have ripped me up with one of his great tusks, and I have seen some very ugly wounds which these have inflicted before now. 
I sent a messenger for Smith, who was full of congratulations on my presence of mind. He then gave me a more explicit account of his adventure with the bear than I had from the man who gave me the news, and I found he had had a much more narrow escape than I imagined. It appeared the brute had actually knocked him down and was about to lay hold of him, when the shikári went to his assistance, and, only for the promptness of the sportsman, it would have gone hard with my poor friend. When Smith first saw the bear he was going from him, so that he could only see his back; firing on the spur of the moment, he only hit him in the rump, when the bear, without a moment's hesitation, charged him, and he fired the second barrel without taking any aim; of course he missed, and on 
looking round for his second gun, his attendant was to be seen scuttling off with it. Smith then retired backwards as fast as he could, keeping an eye on his adversary, but a root or some other impediment caught his legs, and down he fell with the bear on top of him, It was at this moment the shikari came forward and drove off bruin by inflicting a severe wound on him with his spear.

I made Smith promise me that he would not fire any more at tigers or bears till he had gained more experience, for I knew if he continued to do so it would end in his coming to grief some day; he had plenty of pluck, but was a dreadful muff with a gun. I am writing of many years ago, and have since then heard that he is reputed to be one of the best and coolest tiger shots in Bengal. 
But, to return to my own adventure. The shikari now came up and surveyed the dead boar with astonishment, for he said he had been all his life in the jungles and had never seen a larger one; the coolies were called to cut up and prepare the flesh, which process commenced while I amused myself knocking over a few partridges, which I found at the other end of the barley patch. 


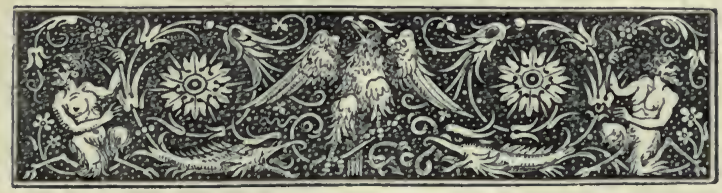

CHAPTER VII.

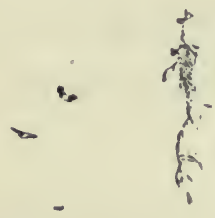

THINK poor Smith's nerves were a little upset by

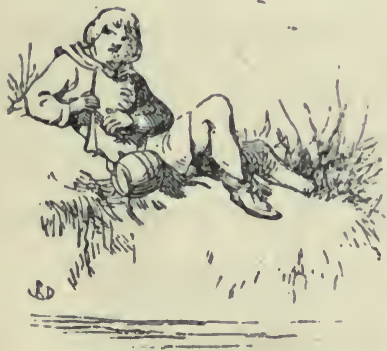

his encounter with the bear, so we determined to make for our encamping ground with as little delay as possible, as we had to unpack some of our loads to get out ammunition and other stores that we were in want of. We 
slowly ascended the mountain where all the packs had been left, and there we filled our pipes and sat down to admire the splendid panorama spread out at our feet, with the snowy range in the background : it was a most glorious view, and the sharp outlines of the snowy peaks were bathed in sunshine which imparted a lovely golden tint to the white snow, adding greatly to its beauty.

We sat for a considerable time enjoying the perfect repose and tranquility of mind, that usually steals over one when quietly contemplating such scenery as we now had before our eyes, and in the meanwhile the coolies had got off with their loads and were slowly descending the hill. ; It is a great object on a march, to get them to leave in good time; it is also highly necessary to keep one's eye upon 
the party frequently during the day, or they will very likely all put down their loads, pull out their hubble bubbles, or pipes, and if undisturbed, will smoke all day long; and their consciences are so elastic that they would have no hesitation in the evening about taking their talab (pay). We were roused at last by the shikari saying, that if we sat much longer looking at the view, we should have to remain the night there, which stirred us into action in a very short time. How true the fable of the hare and the tortoise; though our coolies only crawled along the road, we did not overtake them for miles, and they had nearly got to our next encampment when we passed them. We did not shoot any more that day, as I had an uncomfortable feeling about Smith's escape; and I am sure, poor 
fellow, from what he said on the subject, whenever we discussed it, that his nervous system had suffered.

We determined to unpack a case of the port wine and have a jollification, as I thought it would do us both good. We made a nice fire to leeward of our tent, and there we sat, completely screened from the cold wind, sipping our wine. It is a great pity that port wine is going out of fashion, for I don't know any substitute for it; if a man is weak from ill health, or thoroughly pulled down in strength by hard work, there is not such a "pick-me-up" to be found as a glass now and then of good old port.

We sat far into the night chatting and telling stories; and, on the shikari coming to us for orders about the next day's sport, we insisted upon his sitting down and 
taking a glass of our wine; I imagine he found the liquor to his taste for he did not require any pressing after the first glass, but rolled it down his throat like a seasoned old gentleman who had been in the habit of drinking his two bottles a night for the last fifty years. Of course we chatted about the bear adventure, and he was regretting very much that I had not been near at hand to assist Smith, when he believed the result would have been different. This conversation I thought might be unpleasant for my friend so I changed the subject by asking the shikari to relate one of his tiger adventures, as I made no doubt he had had some hairbreadth escapes in his perilous profession. $\mathrm{He}$ at once assented, but it seemed to us that a sadness came over his face as of some unhappy memory that our request 
had revived; he heaved a deep sigh, and helping himself to a bumper from the decanter on the table, tossed it off and commenced his story :-

" It is now some twenty years since I took to my present occupation, and it was by the merest chance that I did so, for all my family were farmers and have lived on the same land for the last hundred and fifty years. My father and his family are. well known in the district as breeders of the best and strongest hill ponies for many miles round. He has an old pony now, that he has ridden a hundred and fifty miles without taking the saddle off, giving him only one feed of grain, or parched peas, during the entire journey, the pony was not in the least prepared for this long journey as it came about all of a sudden. My mother was going over 
the farm one day looking after, and tending some young lambs; for, as it had been a very severe winter, and was still raw and chilly, she kept them in different parts of the farm in huts erected for the purpose. She had nearly completed her work, and had only to visit the last hut which lay at the extreme end of the farm and close to the low jungle. Before she opened the door she heard an unaccountable noise, but thought little about it, and boldly threw open the door after she had unfastened it. Coming suddenly in from the light, she did not at first observe its occupant, and only noticed a hole in the thatch which she had no recollection of having seen before. Something at her feet now attracted her attention, when, to her horror and dismay, she found herself in the presence of a huge Bengal 
tiger, and near him, lying dead, were several of her lambs whose blood he had sucked, and to this circumstance she attributed her own safety for the moment. Having entered the hut hurriedly, she had gone in a little way-the door pushing open inwards-and now, seeing the enormous tiger stretched out his full length, with his huge head resting on his fore paws, and his savage, sullen looking eyes firmly fixed on hers-she was paralysed, and had neither power to move nor speak; indeed, if she had shouted for help no one could have heard her, for she was quite alone and the hut lonely and detached.

"The tiger now got up, and without taking his eyes away from her, he walked quietly round to the open door and lay down in exactly the same position across 
the doorway. She sank to the ground in terror and despair, and afterwards had no recollection of time, or how long she had remained in a half swooning state, after the brute took possession of the door. When she came to herself it was pitch dark, and seeing (like two balls of fire) the dreadful eyes fixed upon her,-never wavering or winking for an instant,- -she again seemed to loose all recollection, but was fully roused at daylight by the tiger suddenly seizing her in his terrible jaw, jerking her over his back and springing through the open door. My father by this time had become alarmed at my mother's long and mysterious absence, and coming out to look for her, he just reached the hut at this fearful moment; doubtless the brute had heard the approaching footsteps and they had roused him to action. 
" The tiger starting off with my mother seemed to break the spell of her silence, for she uttered a succession of the most piercing screams, and my father, who was most sincerely attached to her, nearly fainted away with horror at the sight he beheld: recovering himself in a second, he rushed from the spot, only to spring upon a horse's back and dash off for assistance, which all his neighbours willingly gave, and he soon collected a large body of well armed men who immediately started in pursuit. My father knew from the direction in which the tiger was heading, what jungle he was making for, so we all galloped off for it, and after going at top speed for a couple of miles, we discovered the brute (who had taken it very leisurely when he found he was at first not followed), trotting on quietly, 
with my mother still lying across his back. He did not even now seem to know that he was followed, and when he reached the jungle he found the party was close to him : now, at last becoming aware that he was pursued, and quickening his pace, he was making for the densest part of it; but my father, who had had some experience in tiger hunting, guessed what he was about doing, and he, with a few others dashing on ahead, got in front of him, and this move seemed to perplex him greatly. Finding pursuers in front as well as in rear, he did not know what to do next, but, after a little hesitation, he made for a thick bush and crept under it, taking his victim in with him. Our kind neighbours were afraid to fire at him for fear of hitting my mother, but my father implored them to fire at him whenever 
they got a chance, as he knew this was the only way to make him charge.

"They must have sent some twenty shots into the bush when, with a deafening roar, the tiger sprang out into the very midst of our party. I shall never forget the consternation and utter confusion that ensued. The first person he encountered was an old man, whom he tore off his horse in a second, but, before he had time to mangle him, my father had put a bullet into the tiger's shoulder, and had got round so as to cut off his retreat into the bush he had quitted. Another of our party gave him a fresh wound, so he began to find it was not all fun, and, turning round, he went off at his best pace growling most frightfully: as long as he was in sight, and indeed, long after he had disappeared, we could hear his dread- 
ful noise. We lost no time in rushing into the bush to rescue my dear and most unfortunate mother. She was alive, but that was all; and, as we expected, most shockingly mangled, so we wrapped her in a sheet and carefully carried her home. In the evening she expressed a wish to see her sister, who lived same seventy or eighty miles distant; my father without any hesitation rode off, and in twenty four hours he had returned, carrying my aunt on the croup of his horse. This was the cause of his having to ride the hundred and fifty miles at so short a notice.

" My poor mother was dreadfully injured, and witnessing her sufferings when we got her home, induced me to register a vow to devote the remainder of my life to the destruction of the cursed breed of animals; I have religously kept it sacred 
up to the present time, and have been at the death of about a hundred tigers already, and I hope to see the destruction of double that number before I become too old to take part in the manliest of all manly sports. Though I had vowed enmity against all tigers, I had doubly sworn it againt one in particular, and I need not say that this is the one that killed my mother, for she did not survive her injuries many days. After she had been buried a week I thought it time to look him up. I knew his haunts and where I was most likely to fall in with him; I also had a private mark by which I could swear to him out of a thousand, this was a very broad black stripe down his side which was quite remarkable; he was also much larger than the common run of tigers and his ears were set further back; 
the brute always keeping them close down, which gave him a most cruel, diabolical expression, so that I felt I could pick him out of a thousand.

“Taking my father's long gun, also his talwár and long hunting knife, I sallied out one evening when I thought the tiger would be thinking of issuing forth to look out for his supper. I walked into the very dense part of the jungle where the trees were so thick that they obscured the daylight; here the place was one mass of bones, and, as I glanced at them in passing, one or two appeared wonderfully like human bones, but I confess my nerves were in too excited a state, to enable me to observe them as accurately as I could have wished.

"I now proceeded most cautiously, knowing the slightest indiscretion on my 
part, or even the displacing of a stone or a bone with my foot might lead to my instant destruction; you can, therefore imagine how daintily I stepped, stopping every few seconds to listen attentively, hoping to make out his whereabouts by his heavy breathing. At last I heard it, and my heart gave such a bound of joy that I feared very much the tiger might also have heard that; but, on my again breathlessly listening, I was glad to find all was quiet, and the sound of his deep breathing was now confirmed. I stood still to consider what my next move should be, and all at once the idea struck mewhy not remain where I was? The deep gloom gave me as great an advantage as it gave him; and I thought that if he came out of his den to yawn and stretch himself, what a splendid 
chance I should have with the long gun. This gun was my mainstay, for when once it was discharged, I had nothing for it but to trust to the talwar and knife, not pleasant weapons to attack so formidable and fierce an enemy as mine was likely to prove; but it was too late now to think of the danger of the conflict, so I looked at my priming, and stepped behind a tree which was so situated that I could overlook the den where the brute lay concealed, for, though I could hear him breathe, I could not see him; if I had been able to do so, I should soon have planted a bullet in his head.

"I think I must have stood behind the tree for the best part of an hour, when I heard a twig crack and knew the fierce battle was about to begin. He came out very quietly and I could see his broad, 
square face and his cruel ears peeping out from under a bush; he was evidently taking a good look in all directions before he showed more of himself, so my hopes about the yawning and stretching were all fallacies, for I could see with half an eye that he was quite as wide awake as I was. I should think he lay ten minutes in this position, his head resting on his paws as he had appeared to my mother on that fatal night. When she told her melancholy story she laid more stress on the dreadful eyes always fixed upon her, than on anything else-the tiger's gaze had paralysed her energies; I am glad to say it had not the same effect on me, for the sight of his ugly face only maddened me with revenge, and I was now thirsting for his blood with an intensity that frightened myself. 
"His reconnoitring must have proved satisfactory, for very soon the creature's body was slowly drawn into view; gradually raising himself up on his legs, at last my deadly foe stood before me. He little knew that a man bent on vengeance was close to him, or he would have felt less comfortable. To my joy I saw him begin to lick his sides, and while he was thus occupied I gently raised the gun and put it through a branch of the tree; but, gently as it was done, the sound caught his ear and he stopped his employment, looking round suspiciously, but seeing everything quiet he resumed the licking of his sides. He was now standing within five yards of me, so I took a steady aim at him-aiming just behind the shoulderand with a firm hand I pulled the trigger : this was followed by a loud roar and an 
explosion which sent me staggering back several yards, and then I tumbled on my back. Of course the tiger's attention was now called to me, and, before I could regain my legs, he was on the top of me and I could feel his hot, fœetid breath on my face. I had presence of mind enough to hold in my breathing and feign death, but I do not think this deceived my experienced enemy, for he gave my arm such a bite that it was all I could do to avoid screaming out with pain; fortunately, I had on a thick leather shooting dress which prevented his drawing blood, for, if once he had tasted that, it would have been all up with me then and there-he would have quietly sat down to his supper, and, after picking my last bone, would have retired into his den to enjoy a 
comfortable snooze till the same hour on the following evening.

"Instead of tearing me to pieces without delay, which I fully expected would be my fate, he would stop every now and then to look at his sides, and I distinctly saw him stagger, so I had hit him after all. He now began to growl frightfully and bite his sides, but I was only just able to see what was going on, for he had put his heavy foot on my chest, and I felt as if it must crush in my breast bone, which is not a pleasant sensation. He now, at last began to lick me preparatory to making his supper, when all at once I recollected my hunting knive, and, gently disengaging it from my belt, I seized it with both hands and thrust it upwards into his chest with all the energy of despair. All the previous roarings 
were gentle whispers compared with the roar that now emanated from his broad lungs, and without more ado he began to maul me most terribly: he broke my left arm at the first bite, and then began to crunch it; the pain forced me to shriek out, and I made the jungle resound with my screams and cries of agony. This seemed to give the detestable brute the greatest pleasure, and he continued mauling my arm, as much as to say: I have found the raw and will work it.

"At length I became insensible, and must have remained in this state a long time, for, when I came to myself it was quite dark, and not even the twinkling of a star could be seen through the thick mass of leaves overhead. I could not at first recollect where I was, or how I came to be there; soon, however, my position 
dawned upon me, but where was the tiger? I felt about with my right arm to ascertain whether my legs were eaten off, or not, and was rather astonished to find them whole; and further examination shewed me that my left arm was the only injured limb, and this was quite stiff and useless. Thinking it would be as well to try and leave so dangerous a neighbourhood, I attempted, with much difficulty, to get on my legs, and, in my effort to rise, lurching on something to the left of me, I fell heavily on my wounded arm; the pain was excruciating and I nearly fainted. After a little while, however, I managed to get up on my legs, and then tried to find out what I had fallen over; and, after a great deal of feeling about, I discovered, to my immense joy and triumph, that it was the body of my 
deadly enemy which was lying stiff and cold within a yard of me,- - so I had won my first great battle.

"I was perplexed to know what to do with myself for the rest of the night, as I did not fancy remaining where I was, knowing that the jungle I was in was full of tigers; and, although I had disposed of one there were plenty more as dangerous. My first thought was to ascend a tree till the morning, but, with my left hand useless, I could not get up into one; to move about the jungle at that time of night would be an invitation to a tiger or a bear to attack me; so I decided upon remaining at the foot of the tree till daylight, when the animals would all be too anxious to get back to their lairs to think of looking me up. I passed a perfectly quiet night, remaining unmo- 
lested, which was fortunate for me as, if I had been attacked, I do not know what I should have done, my gun being unloaded, and I could not have done much execution with the talwár, my left arm being so entirely powerless.

"Mortal man was never more pleased to see the returning dawn than I was, and when the first streak of light came to announce the approach of another day, my anxious fears melted away and my full energy returned. As soon as it was broad daylight I shouldered my gun, having first taken the precaution of loading it, and this gave me a feeling of security as I retraced my steps through the jungle. Nothing molested me on my homeward path, and I reached our house just as my family were about to sit down to their breakfast. My aunt was the first to perceive me, and 
seeing me returning pale, and covered with blood, she uttered a piercing shriek and fell down in a dead faint, when all eyes were of course directed to me, and I perceived for the first time that I was covered with the tiger's blood. When he stood over me I had felt something warm trickling down on my clothes, but I hardly noticed it, for at the time, I did not think the brute was so badly hurt; and, indeed, he might have got over the gun wound but for the hunting knife, which evidently, was the weapon that had given the death blow. My father was rejoiced to learn what I had accomplished, and assured me I had only anticipated him by a few hours, for he had intended going out on a similar errand that afternoon, having made up his mind to rid the country of such a monster, or perish in the attempt; I fancy he 
envied me my adventures, even while he praised my enterprise. Calling some of the men, he at once started off to secure the skin of the tiger: I should have greatly liked to have accompanied them, but my father would not hear of my doing so after he had examined my arm and shoulder, but he ordered me at once to bed; my aunt came to me and applied soothing remedies, for, by this time, my hand, arm and shoulder were all fearfully swollen, and they were afraid to set the fracture till the inflammation had subsided.

"The time seemed to be interminable until the party returned with the tiger's skin, and when they did return and related their adventures I was not suprised at the delay. From my description of the place they had no difficulty in finding the object of their search, but on approaching the 
spot, they were horrified at hearing a loud roar in the immediate vicinity of the dead tiger; however, our people were too much in the habit of being disturbed to be long taken aback, and they were up into the trees in an instant. They were hardly stowed away safely among the branches before they saw a magnificent female tiger steal out of the jungle and walked deliberately to the one I had shot, smelling it and walking all round it. She then began to roar in a frightful manner, when, as if suddenly recollecting something, she walked off briskly, making all the jungle resound with her cries; and, after a little while, other tigers took up the tune, making the whole jungle hideous with their hoarse roaring, but no animals were in sight. Then my father and his party were not long in descending the trees, and 
setting to work to skin the huge beast, and as there were several of them all expert at the task, this was speedily accomplished. They were rolling up the skin when they heard the tigress returning; so, making off in the opposite direction, they ran off with all speed and arrived at home without any further interruption, much to the satisfaction of us all.

"On unrolling the skin and examining it, I found my bullet must have gone clean through the tiger's body, passing close to his heart-if it did not touch it-and the wonder is how he managed to keep on his legs so long with such a fearful wound; besides, the bullet was one of the largest size, as my father was in the habit of shooting large game occasionally.

"During the night a fiery, sharp attack of fever set in ; by the following morning 
I was quite delirious, and for many days my life trembled in the balance; at last the crisis was passed, and, thanks chiefly to my aunt's medical skill, I soon began to gain strength, and in a few weeks I was able to get about as usual; but my father would not hear of any more tiger shooting, and locked up the large gun. I was astonished at the effect this sporting adventure had produced on the bearing of my neighbours; from being looked on as a boy and taken no notice of, I now found myself treated with the utmost consideration and my opinion listened to with great deference and respect."

The shikári had ended his tale, and we thanked him very much for relating such an interesting adventure. He was weary and did not linger with us much longer; but, as he tossed off another bumper of 
port and took leave of us, he volunteered to relate another story, some other evening which he thought would interest us. We were not long in "turning in," and my friend Smith was half asleep while he was undressing; for, when I wished to converse with him about the amusing story of the shikári, I could not get a word out of him, and when he got into bed he was too tired to snore; not hearing the accustomed sound, I thought he must be ill, but on listening again I heard his breathing regular and strong. He was all right the next morning and ready for a start, though he had to be shaken considerably before he could be aroused.

We were a little later than usual in getting off that morning, and I observed the head man did not scold and cuff the coolies with his accustomed energy, and 
that he allowed us to have our cups of coffee without hurrying us, which he was in the habit of doing by locking up our sugar in the patarah, or box in which it travelled, giving us no time to take a second lump. The fact was evident; being thoroughly unused to take any wine, the bumpers he had taken with us the previous night had been too much for him, and he had a splitting headache, if one might judge by the piteous groans he gave vent to, when he thought he was sufficiently far from us not to be heard.

Our course to day was over some bleak plains and steep mountains, so that I do not think we fired a shot. We were on our way to a famous jungle where we believed we should be repaid with good sport, and, as the result proved, it was well worth the journey, though the road 
to it was long and dreary. We encamped that night on the edge of the jungle which appeared to be of great extent; it was densely clothed with low bushes and a rank, tall grass, which made it exceedingly hard work finding a passage through it, and there were very few open spots where we could get an easy shot: our only chance was to walk along as quietly as possible and without speaking. Sportsmen make a great mistake in talking; it is a very frequent habit, which in my opinion should be relinquished; for the wild animals have the greatest horror and fear of the sound of a man's voice, and make off directly they hear it; but they are so often accustomed to hearing a heavy tread in the jungle, that they do not so much mind it. By advancing quietly and cautiously, animals will let you get 
within a few yards of them, whereas, noise and shouting only drive them away altogether.

Before going very far, a splendid buffalo bull sprang up just in front of me, and I let drive at him, but did not touch him in a vital part. In a second he turned, and, with his formidable horns lowered, he came full at me; not expecting such marked attention, I was unprepared to give him a shot in the head, so I popped behind a tree (which fortunately I was just passing at the time), and I was none too soon, for the top of his horn took a piece out of my shooting jacket, which, however, was better than taking a bit of my flesh along with it. He pursued his headlong course, knocking over one of the coolies in rear, which caused a wonderful amount of chattering 
and conversation among them for the rest of the day.

I had not gone much further, before a large bear jumped up with a loud surprised snort out of some thick bushes; he had reason to be more surprised, when I planted a bullet at the back of his ear as he had the impudence to stop and look round. He dropped like a stone and lay there perfectly motionless, so much so, that I was afraid to approach him for a time, thinking it was but a trap to catch us, many sportsmen having lost their lives by running up to wounded animals, who, in the mean time, partially recover, and then their rage is fearful, and they shew no mercy; so we advanced very cautiously on our friend bruin. I directed some of the beaters to throw stones at him, when, as he did not stir, I went up to him slowly 
with both barrels cocked-but he was dead. The coolies uttered a scream of joy, rushed at him with their knives, and in a few minutes his nearest relative would not have recognised him. I desired them to keep the two hams and the skin for me, and they loaded themselves with the rest, anxiously enquiring where we were going to encamp, as visions of bear steaks presented themselves to their view.

We continued to shoot till it was almost dark, and made a very good bag, consisting of a fair supply of partridges, jungle fowl, hare, and a couple of jakoor, or Himalaya pheasant. This last is a beautiful bird, but a man must be thoroughly master of his gun before he can hope to bring one of them down, for they fly like the wind, and the pace they dart down the 
rhods, (ravines) of the mountains, is an "eye opener." Smith had shot very fairly, among other things, knocking over a jungle sheep which we found delicious eating, and it was very tender. As Smith had been so successful with his gun, he was in wonderful spirits, and we sat up far into the night talking, and smoking, and rehearsing every good shot that we had made during the day; and as we had had very hard work, Smith as usual undressed when half asleep and had not energy to snore. I really thought that this hard work had broken him of that vile habit, and I threatened to patent the idea on my return to England. I was too tired to sleep, and then the responsible position in which we had placed ourselves, began to dawn upon me for the first time. Though we had not agreed to feed the followers, 
we always did so, and the small supply of flour they had brought with them, was by this time all exhausted; no matter how successful we were in shooting, by the evening of the next day, not a scrap of anything was left, and we were too far from the cantonments to be able to purchase supplies. As long as we had our health, and could daily come across large game, all was right, but let us only be prevented from shooting for a couple of days, the camp would be destitute of provisions; however, I trusted to God's goodness to keep us from such dire calamity, and I think from this time, we made better bags than we had done before. The truth I suppose was, that we were getting more accustomed to the work, and could now fire at the largest game without getting flurried in the least. 


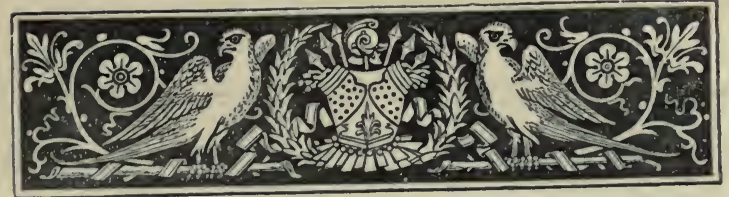

CHAPTER VIII.

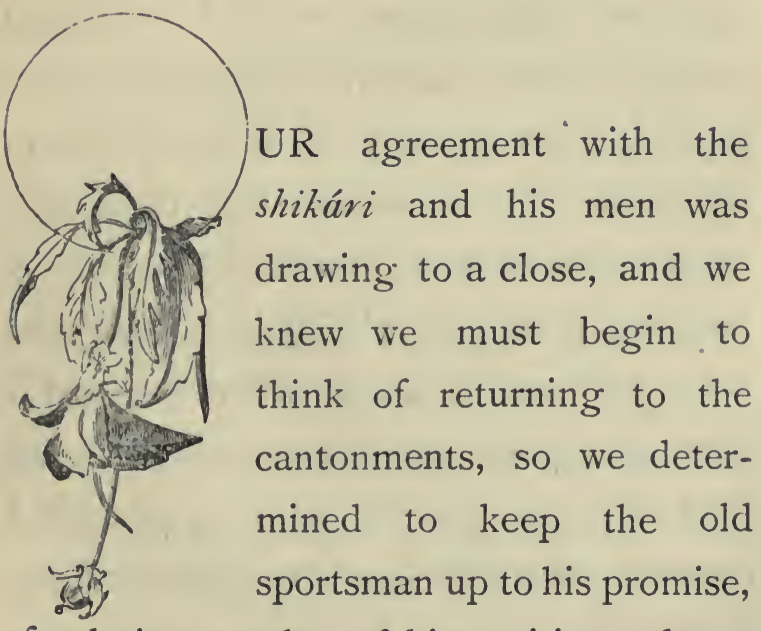
of relating another of his exciting adventures. When I invited him to join us that evening, I saw by the twinkle of his 
eye that he had remembered one, which he thought would do him credit; he came in just as our dinner was removed, but nothing would induce him to touch the old port wine, so we both abstained from it, and ordered a supply of coffee instead. The shikári having finished his first cup at a few gulps, began :-

"You must know, súhibs, that in pursuance of my vow to devote the rest of my life to the destruction of tigers, (and with these I included all other dangerous animals, ) I had chalked out for myself a life full of privations, hardship, and great peril; but, once having made up my mind to it, I was not the fellow to draw back, or to repent what I had done. I prevailed on my father to give me the big gun, which I polished and cleaned up so successfully, that no one 
would have recognised it as the rusty dirty weapon, that used to hang over the kitchen fire place; and I also resolved that when I had saved enough of money by the sale of skins, I would devote it to the purchase of a double barrelled rifle.

"One day I began to think it was time I should be doing something, towards enabling me buy the much desired new gun; and as I had long since recovered from the mauling my first and only tiger had given me, I determined to delay no longer, but to sally forth at daylight the next morning. This resolve. I put into practice, and started off for the jungle just as the sun was beginning to rise, for I knew this was about the hour when the animals would be hurrying home after their night's feeding, and if I hastened on I might intercept one, before he could gain the 
repose and tranquility of his own den. I stepped out briskly and soon reached the jungle; but, instead of turning my steps in the same direction as I had taken the last time, I took an opposite one, and began to traverse the jungle with great caution and care; I did not put my foot to the ground without looking first if there were any twigs to snap or get displaced, and in this manner, I quietly advanced a considerable distance without seeing or hearing anything to interest me. Sometimes I would catch a glimpse of a large snake-the deadly cobra-gliding off in front of me, but this was all that attracted my attention, during the first hour I traversed that lonely and desolate jungle. I proceeded on, and at last, after I had passed a part of the jungle that was a little thicker than usual, I heard a great rush, and a 
crushing of boughs and small trees, as if some very large animal was forcing his way through the bushes at headlong speed. From what my father and the shikáris had told me of these matters, I felt sure it must be a musk elephant, and he is the most dangerous of animals. A musk elephant is a male one, who is driven out of a flock of elephants by the other males, and this does not occur, till he has fought them all and been beaten by them all in turn; he then leaves the tribe to wander into the jungle by himself, and . being now dreadfully sulky and illtempered, he amuses himself by doing all the mischief he can ; and he is then most dangerous in the way of attacking travellers, who, in consequence, have a wholesome dread of him.

"I had hardly cast this up in my mind, 
when the brute was almost close upon me, and I had only just time to spring aside, when he dashed past me with a shrill scream; he was going at such a pace that he could not pull himself up, and, as he shot in one direction, I shot off in the opposite one. Knowing him to be such a dangerous animal, I felt that the greater the distance I put between us, the safer I should be, so.I ran as hard as I could and heard the beast beating up the jungle in his efforts to find me. Very shortly I could tell, by the noise he made in crashing through the bushes, that he was following me closely, so I made up my mind to give him battle.

"On came the elephant, and I had only time to get behind a large tree and poke the long barrel through the branches, when he dashed into sight, and, catching 
a glimpse of me at the same moment, he come forward like an arrow from a bow. As his head was down in the act of charging, I tried to cover the little hollow in the skull just above the eye, which is a fatal spot if you can hit it; but, from the flurry of firing in haste, and the pace he was going, I missed the mark and saw my bullet flatten on his skull. I knew it was all up with me if he caught me; but, the moment I saw my bullet flatten on his head, I was convinced it would at any rate stun him for a few seconds; so, pitching my gun down, I lost no time, but made off at my best pace. I was right about the bullet bothering him, for turning quite round, he appeared to have lost all recollection of me, and looked as if he intended to subside into a respectable family elephant, who would bring up his little 
ones to be a credit to himself and the herd to which he belonged. This was quite a delusion, for I had just cleared the open, and once more got into the thick jungle, when on glancing back, I saw the demon had again entered him, and that he was as fully bent on murder, as before he had felt my bullet cracking on his skull: this had certainly bothered him for a while, but he had soon shaken off the surprise, and was himself again, hence his pursuing me with such vindictiveness.

"I had got a little start of him, and resolved to make the most of it, by dashing head foremost into the densest part of the jungle; and where I could not penetrate in any other way, I crawled along on my stomach, gliding through like a serpent. I was glad to find that these dodges of mine perplexed him, and, at last, I could 
hear him stop to listen, which shewed me that he did not exactly know my whereabouts. At this moment I sneezed-most likely in crawling under the bushes some insect got up my nose-at any rate I was unlucky enough to sneeze, and the moment I had done so I heard the bushes in violent agitation, for he now knew in what direction to find me: twice he essayed to come to me but was obliged to try back again, and I, acting on his plan, retraced my steps and crawled back, so that when he occupied my old resting place I was in his, much to his disgust. - I then sped away to where I had left my gun, picked it up and began to load with all possible haste. The cunning brute heard me ramming down the bullet and was on me as soon as I could prime. I got into the old spot and put the barrel 
through the branches as before; this time he did not forget the lesson I had taught him, for he advanced much more cautiously, and at a walk.

"Again I missed the fatal hollow, planting my bullet in his right. eye. I do not think I ever heard such a cry of pain and rage as burst from him now. I was quite stunned by the noise, and before I could recover myself he was nearly on the top of me, for he threw me down and tried to kneel upon me, but, luckily, I always managed to wriggle aside in some way, so that he could never contrive to throw his whole weight upon me, which was what he evidently wished to do. Failing in this, he endeavoured to transfix me with his formidable tusks, but I was always between them, so he could not hurt me much. This went on for some time, till I became 
so exhausted and worn out with repelling his attacks, that I commended myself to God, feeling that nothing short of a miracle could save me.

"Suddenly the elephant thought he would try a new dodge; jumping up and winding his trunk about my body, with a tremendous jerk he sent me high up into the air: I came down crashing into a high, thick tree, and, to my vast satisfaction and immense surprise, I found myself safely caught and reposing in its thick, sheltering branches, and there I lay quite conscious, but without strength to move hand or foot. I could see through the boughs that the elephant was running about, to try and find out what I was doing; but, having had quite enough of his company, I determined to remain where I wảs. 'Rest and be thankful' was now my motto, and. 
I was only too happy to have my life preserved in so miraculous a manner. The elephant continued to run about very excitedly, and seemed as if he could not rest for a minute at a time; he could not form the slightest idea where I was, and I had not the least intention of letting him know.

"I either fell off in a deep sleep about this time, or else fainted away, for when I awoke, or came to myself, the moon was shining as clear and bright as day, and the night was heavenly, and the fever of excitement that had so lately coursed through my veins was succeeded by a calm and regular pulsation. I felt refreshed and invigorated by my rest, and began to wonder how it was that I was perched up in a tree; then gradually the whole affair came to my recollection, and 
I longed to find out what had become of the elephant, when, on peeping down through the branches, to my surprise I saw him resting on his knees with his head supported by his tusks. I lay still, till again drowsiness overcame me, when I dropped off to sleep. When I awoke the sun was high in the heavens and I felt throughly refreshed and strong, and very grateful for the wonderful escape of the previous day. On looking down I was surprised to see the elephant still in the same spot and in the same attitude, and I observed that he did not appear to be in a natural position: I then saw several wolves and jackals hanging about, when it occurred to me all in a moment that, after all, my shot in the eye must have killed him. I descended the tree cautiously, and did not leave its friendly trunk till I saw one of the jackals 
biting at his foot, and I knew that, if the elephant had been alive, he never would have tamely put up with such an insult as that; so, leaping down to the ground, I approached him and found he was quite dead and stiff.

"How I gazed on his enormous bulk! In the excitement of my joy I mounted up and stood on his back. But what most riveted my eyes and filled me with delight, were his enormous tusks, for I saw they were thoroughly good ivory, and here at once was the price of my new gun! Having nothing with me that could remove them, I picked up my gun again, and, quickly loading it, I threw it over my shoulder and made for home as rapidly as possible. I was not afraid of any one stealing the tusks, for the jungle had such a bad name that I bejlieve no native would have 
taken a thousand rupees to go a hundred yards into it. Nevertheless, I hurried home and arrived there in a comparatively short time, although the fear of encountering a tiger, or an elephant, never disturbed my mind: in my battles with both these animals I had come off victorious, so that I began almost to despise all wild animals, and I have never feared them since.

"My father was out when I returned, and nothing would induce the men to go for the tusks unless I accompanied them; so, snatching a morsel of bread, and tossing off a jug of new milk, I started off with them and found the dead elephant without any difficulty. We soon knocked off his tusks and the men insisted upon taking the feet also, as they are considered a great delicacy when baked in a hot oven for several hours. We got back before 
sunset and my father had not yet returned home, but, while we were examining and valuing the ivory, he rode up to the door, and his astonishment was great when he saw proofs of the second victory his boy had won. I may now tell you that the money I got for the tusks enabled me to purchase my double barrelled rifle; and if I had had it in my hand on that occasion, instead of the long barrelled gun I should have probably saved myself all the mauling I received from the elephant."

The shikári had kept us wide awake with his exciting anecdote, and we talked it over before he wished us a good night, when, gulping down another cup of coffee, he strode off to his own little tent, leaving us in astonishment at his determined courage, and at the same time in admira- 
tion of the simple modesty with which he related his adventures.

We were off the next morning at daylight on our way back to the cantonments, and, although we had a little shooting on our road, it seemed tame to us after the splendid sport we had enjoyed. I never knew what shooting was before, and shall never forget the three happy weeks we passed in the Himalaya jungles; though I have had many a pleasant time of it since then, in other parts of the world, yet it has lacked the freshness and novelty of first experiences.

As the weather came on to be wet, we had a good deal of cold rain and muddy travelling, which made our coolies look very miserable, so we gave leave to as many as we could spare to make for their 
homes, and Smith and I started off with a guide; after a tremendous day's walking we arrived late in the evening at our hotel, and sat down with thankfulness to our mutton cutlets and curry and rice. I was not sorry, after all, to get back to the comforts of a house again, for the last few days had been very wet, and no one, who has not experienced it, can realize the discomforts of travelling in the Himalayas in bad weather; the natives dislike it so much, and look at one so beseechingly, to help them out of it, that you feel as if you were murdering the poor fellows by subjecting them to the dreaded wet and cold; and, though we hurried on as fast as we could to cantonments, still two or three of our men were very ill on the road, and the shikari told us the only thing that could save them was to get them into 
their own comfortable huts with as little delay as possible. We had no trouble in settling with our shikári as he was an honest man, and, therefore, contented with what we had agreed upon, and he was also grateful for what he received ; so we parted excellent friends, and I must confess to a feeling of sincere regret when the good old sportsman took leave of us.

My six months leave was nearly up, and, being so well in health, I had not the wish to get an extension of it ; indeed I looked forward to meeting my regiment again with much pleasure, for in the east, you regard your brother officers as the greatest friends you have in the world; the same feeling, perhaps, applies to regiments at home, but it is in a lesser degree: in India you are thrown so much on each others' society, and the knowledge that you 
will be together probably for years, serves to cement friendship. At the hotel I found a letter from the adjutant of the regiment, who wrote by the desire of the commanding officer, to say, as he heard I had been on a shooting tour, he requested that I would rejoin the head-quarters without delay; for, if I were well enough to go out shooting among the Himalaya mountains for a month, I must be strong enough to do my duty with the regiment. I wrote to the adjutant, for the commanding officer's information, that I was prepared at once to rejoin the head quarters; and when my letter was ended, I lighted my cheroot and thought over my next move.

The result of my meditations was, that I should immediately send to the kotwail, desiring him to let me have twenty coolies the following morning, to carry myself 
and my belongings down to the foot of the mountains, and, acting on this resolution, I at once started my bearer off to make arrangements. He very soon returned, bringing me a message that every coolie was engaged in carrying up stores for a sandágar, (native merchant) so that I could not have any till the day after ; there was nothing for it but to wait with patience till it suited their convenience to attend to me. In the mean time Smith, who was not returning to his regiment for another month, and who was delighted at my unexpected delay in starting, proposed that we should have a walk in the bazaar, which is the place where all the shops are situated, and where all the business is transacted; so we put on our hats, after lighting our cheroots, and started off for our stroll. 
The bazaar in the hills is (or I should say was at the period of which I write) a very poor and indifferent one compared with those at large stations, such as Cawnpoor and Delhi ; in those places you can buy any article, from a pin up to a new carriage, and, as to ladies dresses, or cloth for gentlemen's suits, if you expressed a wish to see any, you would be nearly smothered by the rolls they could produce. I believe there are no people in the world so enterprising as the natives of India, and their love of money makes them such persevering salesmen, that you are seldom allowed to leave a shop without buying things you do not require. We strolled from one end of the bazaar to the other, but not a thing could we see tempting enough to purchase. I wished to take down some little trifles from the 
Himalayas to my chums in the regiment, but the only articles of the kind that I could procure, and they were brought out from some hiding place at the back of the shop, were pretty cigar cases made of leather, with split quills inserted in them by way of ornament : these can be bought for two or three rupees, and they were not a bad present to take from the hills, as it was the only place, in my day, where they could be procured. Having secured the cigar cases, I persuaded my friend Smith to accompany me to a high hill which not only commanded a full view of the plains, but also of the high mountains running back from where we were standing. These mountains rear their summits higher and higher, till they terminate in what is called the "snowy range," where-as their name implies-there is perpetual 
snow; and it is beautiful to see from the plains below, where you are stifled with the heat, those lofty peaks looking so purely white and cool.

The reason I required so many coolies was, that my baggage was considerably increased by the number of valuable skins now in my possession; and while I was thinking about them that evening, it struck me, and a most valuable thought it was, that they should be looked to before my departure for the plains.

No sooner said than done; a man cunning in dressing skins was applied to in the bazaar, and he said he would call in the morning to see the state they were in ; as nothing had been done to them from the time they had been stripped off their late owners, it was lucky for me that I had them examined when I did, or 
they would all have been irretrievably spoiled.

The man came the following morning, and found they were all getting into a state of decomposition; but by the rubbing he gave them and the preparation he put on, they were saved for the time, and he suggested that when I reached the cantonments I should get a man accustomed to the work, to take them in hand, and properly dry and prepare them for the voyage home. I may here mention that I followed this advice, and they arrived at my Irish home in due course of time in first rate condition, where they were duly exhibited to all my relations and friends as "Master John's" work; and those who had only seen me knock over a snipe, or a wild duck, thought I must be very much improved in my shoot- 
ing to be able to kill a bear, and a bison.

The day of my departure at length arrived, and I was awoke out of a very sound sleep that morning by great chattering under my window, and I did not require to be told that the coolies had arrived. I jumped up at once and was soon dressed, and as most of the things were packed over night, it did not take long to complete my portmanteau, strap it, and hoist it up on the head of a coolie. I must say my attendants, who were natives of the plains, worked well, for they were all dying to get back to their homes again, as the mountain air is much too cold for them : as a rule they will sit shivering all day long, their teeth chattering from the cold, morning and evening. I fancy this is very much the way they passed 
my sick leave in the hills; but now, with a prospect of leaving, their jokes and laughter were something wonderful to hear. My old fat cook, Beto, was in such spirits that he began to sing, but in such an unearthly voice that one or two of the coolies dropped their loads, and would have taken to their heels, if their chief man had not requested him to reserve his vocal powers till a more fitting opportunity.

We rapidly descended, and I had never seen anything more lovely than the road we were travelling; the foliage was luxuriant, and the surrounding hills were clothed in it to their very tops, abounding in beautiful flowers, and we had quite an abundance of wild strawberries, which grow there in the greatest profusion. We gradually reached the foot of the hills; 
and after I was installed at the hotel, and had counted the loads, found all right, and paid the coolies, I began to consider how I could get forward on my journey. I went to the post master about palanquin bearers, and he promised I should have them in the morning; then I hired a hackery, which I ordered to be at the hotel in an hour, in order that it might then be packed and made ready to start at daylight next morning. I went back to my hotel and sat down to dinner with a light heart, having satisfactorily arranged all my affairs. I should like to impress on my young readers the necessity of always doing their business first, and afterwards they may study their own comforts, and enjoy themselves. In a country like India, where every one has a habit of procrastinating, it is absolutely necessary that you 
should arrange with the natives yourself, or you will find, when you are ready to start in the morning, that the hackery for your boxes has not come; or, perhaps, the bearers for your palanquin have not arrived, and you may lose half the day in running after them; or, perhaps you find matters worse than that, somebody else has boned them!

My forethought and good arrangements were rewarded by seeing the hackery slowly creak itself out of the compound of the hotel at the intended hour; and then, after taking a cup of coffee, and taking leave of my friend, Smith, and of the obliging landlord, I stepped, or rather scrambled, into my palanquin, which was lifted up on to the shoulders of the bearers, and off we went at a quick shuffle of about four miles an hour. 
I must own that I felt heartily sorry to leave the beautiful hill country, whose climate had invigorated my enfeebled frame, and whose wild jungle had afforded me so much exciting sport. The many dangerous scenes I had passed through, only served to make my happy escapes stand out more prominently, and my memory recalls this, as one of the pleasantest six months of an eventful life. 


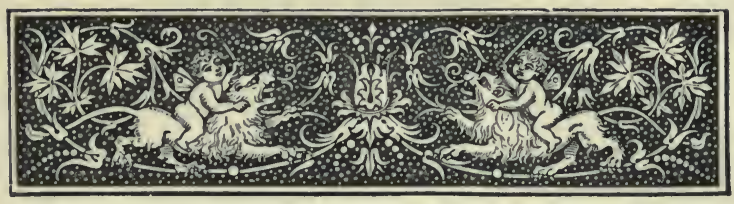

CHAPTER IX.

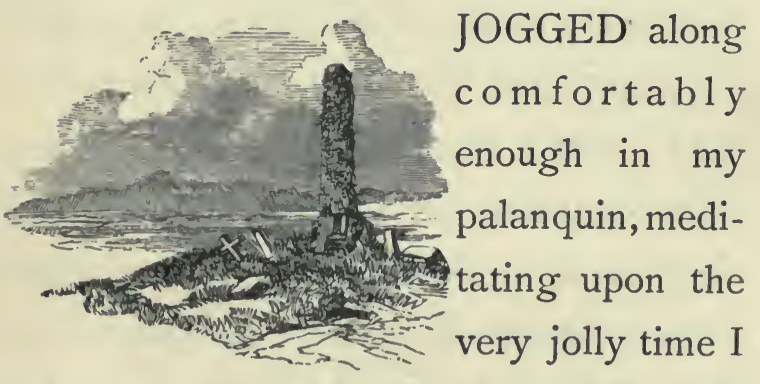

had passed in the Himalaya hills and wishing it could all come over again; and then I thought I would act differently in this case, and in that; that I should have allowed this bear to charge more home before firing, or that buffalo to get away a little further, and so on. In this manner I 
beguiled the time till it was getting near sundown, and still my bearers were rapidly getting over the ground. I then took a cheroot, and, leaning back in the palanquin, closed my eyes: after a time I was sound asleep, and I think I must have had a good long nap, when I was awoke by a crash and a great shock; on starting up to ascertain the cause, I found the bearers had let the palanquin fall, and that they were scuttling off into the jungle at their best pace, screaming out "bágh bágh" (tiger, tiger), at the top of their voices. It was pitch dark and raining steadily, as miserable a night as I ever recollect, and my first care was to pull the sides of my palanquin together quite close, and then I held in my breath to listen. Presently my ear caught the sound of a stealthy step, as of some large animal, approaching, 
and I heard him sniffing all round the palanquin : feeling sure it was a tiger, I congratulated myself on having closed the doors, but I knew they would only be a very small protection when he had warmed himself up to his work. He crept round several times, sniffing all the while, and each sniff seemed to me to be louder and more determined than the last; and then I heard a sharp scratch against the side of the palanquin, when I knew at once that he meant business.

The moon now shewed herself slightly, and, contriving to peep through a crack in the panel of my conveyance, I saw, as I had feared, a very large tiger a little way off, crouched on the ground,- - his eyes flashing like fire and firmly fixed on my unfortunate palanquin. I knew the decided moment for action was come, so, opening the far 
sides with a jerk, I bounded out at the same instant that the tiger landed head foremost through the broken panels on the other side of my palanquin Seeing a tree within a few yards of me, to seize a bough and spring up into it was the work of an instant; and, before the tiger had recovered from his surprise, I was well up in the branches, and, for the present, out of danger. My consternation was great at finding myself clothed only in a shirt and páe-jámas (muslin drawers), in the middle of a damp tree on a chilly night; and, to add to my misery, I had not the slightest idea what hour it was, or how long I should have to remain there. I knew that the tiger would be obliged to make a start of it at daylight, as we were on the high road where many people would then be passing, 
but how long it would be before daylight appeared, I knew not.

I kept my eyes steadily fixed on the brute, who knew well where I was, and who indulged in many a long stare at my expense. At last he crawled away into the jungle and took up a position under a bush, within easy springing distance of the tree I was in: I could see his fiery eyes peeping out all night, and I dare say he was wondering why I did not descend, and allow him to have his supper comfortably, instead of leaving him to lie under a damp tree, starving with hunger. The tiger must have had a very poor opinion of a man's understanding, if he fancied for a moment that I would descend to gratify his appetite; but, no doubt, he imagined himself so well concealed that I would fancy the coast was clear and would 
come down after all. How wonderful it is that every animal thinks he is so much more knowing than another! and the human species are not exempt from this infatuation.

I never recollect a night that passed so wearily, and I was glad when I saw the first streak of day appearing. The dawn is very short, as I have before mentioned, and, in ten minutes more, it was broad daylight. I had observed that my enemy had for some time been very uneasy; and now he got up, and, with head and tail hanging low, he skulked off across the road, disappearing in the thickest part of the jungle. Though I could not see him, I was able to track his course, by the bushes shaking as he passed along, a sadder and, it is to be hoped, a wiser tiger than he was when he left his family residence! 
I now heard great shouting down the road, and very soon my palki bearers approached most cautiously, calling out to me to know if I was alive, of which, from their manner, they had very little hopes. I shouted to them in return, and then they ran up to me, and I really believe were heartily glad to see me safe and sound. It appeared from their version of the story, that while they were jogging along in the dark, the bearers ahead had suddenly seen the tiger's eyes flaming at them from under a bush: not thinking he was perceived, he no doubt had intended to let them pass and spring out on the rear man; but all the bearers taking fright, the clatter of the falling palanquin must have upset his nerves for a time, and he therefore let the whole party escapemyself happily among the rest-and hence 
had to go home in the morning low and dejected.

We did not waste much time over the broken palanquin, but proceeded on our journey at once, for we were in a dangerous neighbourhood, and, it being onlv the panel that was smashed, we got on as well as before the adventure.

The road was extremely good, as main roads in India generally are, and we pushed on at a brisk pace. I think my bearers had got an idea into their heads that the tiger was jogging along after them, and this kept them up to the mark, till they changed places with the fresh relay of men: By the evening we had reached the banks of a river which I should have to cross ; but, as it was very high and much swollen, I found I must remain on the bank till the water had subsided in some 
degree, and I slept comfortably enough in my palanquin by the river side.

My servant was bringing me a cup of tea in the morning, when we heard a fearful screaming from the water's edge not far off. I jumped out and ran to the spot to enquire what all the screaming meant, when I was told that a huge alligator, that pest of all Indian rivers, had dashed into the midst of a number of women bathing, and seized upon the unfortunate girl whose piercing shrieks had reached my ears; and, dragging her off into deep water, they had both sank together. The poor girl was just about to be married, and the intended husband was running about like a maniac, tearing his hair, and cursing not only the alligator himself, but all his family; and he was continually spitting on the ground (which I suppose 
represented the family) to shew his great contempt for them all. This would have amused me at another time, but I could not help feeling pity for the poor fellow, who was so dreadfully cut up that he blubbered like a child, but there was no help for him.

During the day I hit upon a plan to punish this monster in scales, for, as the river was still rising, it was pretty sure that I should be detained here for a few days longer. I first sent to the blacksmith in the village, to make a large iron hook with a sharp point, and a strong chain from its shank ; this order he carried out fairly well, and the apparatus came in the evening. The next morning I was up betimes and got a large piece of pork to put on the hook; I pushed the meat well to the back, so as to leave the point free, and as there 
was no barb on it I determined to hold it myself. About the same hour that the unhappy girl was carried off, on the previous day, I went to the water's edge, at the same place, and threw my bait and hook as far in as I could, playing it about in the water. In a very few minutes, feeling my bait move, I struck at once with all my strength; I knew I had him, for I experienced a jerk that nearly threw me on my face, and I should have been pulled into the river if I had not shouted out to the bystanders to assist me. Every part of my tackle was so strong that I resolved not to give him a chance, but to " run him in" at all hazards. We called out lustily for assistance, and soon three or four dozen men were hanging on to the line. Being so strong a party, I gave the word, and we got way on him, and then ran 
him up on the bank at once, no doubt quite as much to his astonishment as ours.

He was a monster in size, and although I had seen and shot a good many alligators, I never remembered seeing one so large. It took us, I should think, half an hour to kill the brute, the whole population turning out with láthies (thick sticks), men, women and children all pounding away at him; and many were tumbled over by the sweeps of his powerful tail. When I said it took half an hour to kill the monster, I should have said, that it was fully that time before the edge of his fury, was taken off, for I do not think he was really dead, for twenty four hours after he came out of the river. I ordered the men to open him, when a strange medley of objects were discovered in his stomach. First, there were portions 
of the unfortunate girl, his last victim-such as a foot, a hand, and the wrist with the silver bangle, or bracelet upon it, which was recognised by numbers of her friends who had seen her constantly wear it. There were also a kid, a portion of a pariah dog, and some fish in his capacious maw.

I then cut off his head, which I have had preserved, and it is still a source of wonder to my lady friends, and a terror to their children. Before leaving on the third morning, I went to see the carcass, and it was still wriggling about. The tenacity of life that these brutes display is most remarkable, but surely this could only have been a muscular motion. The river was now falling, and the villagers informed me that it would probably be safe to cross on the following morning; so, to pass the intervening day, I got out my gun, 
which had been carried on the top of my palanquin during the journey, and amused myself by shooting wild duck and widgeon on the river; and, as people, when travelling dák in India always have an extra coolie to carry the petarahs - (boxes made of tin,) which hold a good many clothes, besides other necessaries, one is always well provided wherever one is obliged to stop, and the palanquin forms a house and bed combined.

Before starting that morning I went to look at the alligator and felt very much inclined to believe, that if he had been shoved into the river, then and there, he would have floundered off into deep water, and disappeared to frighten other alligators who should have seen our friend swimming about, without his head! I crossed quite comfortably after breakfast and arrived at 
the cantonments in a couple of days. I foundall myoldchums well and delighted to welcome me, and I do not remember ever enjoying a dinner so much as that night's at mess, when we sat on into the small hours, asking and answering questions, till an old Captain jumped up and reminded us that we had an early parade the following morning. A brother officer had given me a shake down in his bungalow, so I turned in and had a good night's rest.

The warning bugle awoke me just at daylight, and, getting into my uniform, I turned out to make my way on foot to the parade ground. A led horse intercepted me, and, from the pleased grin on the face of the sáis, and on taking another look at him, I recognised my own man with whom I had left the Arab in charge. My friend 
had ridden him ever since I offered to lend him while I was in the Himalayas, and my sáis had now reclaimed him for my use. $\mathrm{He}$ had grown a magnificent creature, and I jumped on his back and cantered to the parade. After the usual two hours drill we were dismissed, and I felt quite gratified when many of the privates came up, to say they were glad to see me well again. Soldiers, as a rule, are kindly dispositioned and warm-hearted men, and when once attached to their officers will follow them faithfully through every peril. I had been an object of interest both to the men, and officers in my regiment on account of my sufferings, and my escapes out of the hands of the natives in Nepaul, and I think few of them expected to see me among them again, when I first started for the Himalayas. 
I was now fit for duty, and took my guards, parades, courts-martial, etcetera, as they came; and the station being particularly gay at that time, my life was a very pleasant one. We got up theatricals in the regiment, and having always had a taste for acting, I took part in most of the plays that were produced. All this, however, was too much happiness to last, for, before I had been back with my regiment three months, I was again laid up with fever, which gradually got worse, instead of better, and I was nearly at death's door. The medical officers were at their wit's end, as I declared I would not go home; but, as I did not mend, the serious question was at last put to me by one of my doctors, whether I preferred remaining in India to die as a certainty, or going home to be cured in all probability, by the 
change of climate, and I had no resource but to decide upon the latter.

As mine was considered by the learned ones a very grave case, no time was lost, and a medical board assembled. They merely put a few words to me, and then I was told that I had passed the board, two years sick certificate being granted me to go to England. The president, in the kindest manner, earnestly urged upon me the necessity of making an early start of it, in which, he said, all the members of the - Board concurred; and, after they had wished me a safe passage and restored health, I left them, I must own, greatly depressed at the unpalatable mandate. Taking leave of my brother officers sent my spirits below zero, and when I started that same evening for Calcutta, I felt much more miserable than ever I did, in the 
Nepaulese prisons. Now those days of peril had glided into the past, all the wretchedness of them was well nigh forgotten, and only the excitement of the adventures lived in my memory. The shooting in the hills was a never-failing subject of pleasant remembrance to me, but there was some pain in the thought that I might never enjoy such sport again; yet, in spite of all the croaking of my medical advisers, I did not lose all hope of a perfect recovery, and a return to India.

I duly arrived at Calcutta and felt a little better already from the change of air and scene, though much worn out by the journey. My agents provided a passage in the "Lord Lowther," a very fine ship, and we set sail the following day at sunrise. We had a good number of 
pleasant passengers on board, and what with their cheerful society, and the bracing sea breezes, I was a different man in a month, and no one would have recognised me as the weak, emaciated invalid who was carried on board the "Lord Lowther," probably to die on the passage, which I knew was the opinion of all my friends. In due time we landed on English shores, and, after reporting myself in London at the Horse Guards, I started off by the mail train en route for my Irish home, where I regained my strength in such an incredibly short space of time that the medical board in India would have been astonished had they seen me; for they had, I believe, but faint hopes of my recovery, even at home. "While there is life there is hope," and my case was another illustration of the truth of this 
happy old adage. Thus ended my adventures in India for the present, but I resolved to be laid up on the shelf no longer than my two years sick leave necessitated.

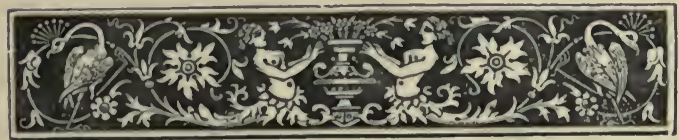


LoNDON :

Printed by Turner \& Co., St. John's Gate Printing Works, E.C. 


\section{Fames Blackwood \& Co., Publishers,}

\section{USEFUL WORKS.}

I. TAKM MY ADVICE; A Book for Every Home, giving com. plete and Trustworthy Information on everything pertaining to Daily Life. Crown 8vo, cloth, Illustrated, price 2s. $6 d$., $360 \mathrm{pp}$.

Contents-Household Management-Domestic Cookery-Brewing and Distilling-Domestic Medicine-Domestic Chemistry-Clothing Garden Management-Law of Agreements, Leases, I O U's, Bills of Exchange, \&c.-Trade, Artistic, and Scientific Facts-Etiquette and Manners - In-door and Out-door Games-Domestic PetsDomestuc Pests - Ladies Work-Something for Everybody-and other matters. By the late Editor of the Family Friend.

* This is one of the most complete books of the kind ever offered to the Public, and published at an unusually low price.

2. THE BOOK OF DATES; or, Treasury of Universal Reference, comprising the principal Events in All Ages, from the Earliest Records to the Present Time. With Index of Events and Numerous Tables of Permanent Interest to the Student. Demy $8 \mathrm{vo}$, cloth, price Ios. $6 d$., more than 800 pages of closely printed matter.

3. A COMPLETE PRACTICAL GUIDE TO HER MIA. JESTY'S CIVIL SERVICE; containing in full the Exami. nation Papers for every Department used since the Appointment of the Commissioners ; Full Details of the Limits of Age and Qualifications of Candidates; Hints to Candidates for every Office ; and Copious Tables of the Emoluments and Superannuation Allowances of every Civil Servaıt in Great Britain, Ireland, India, and the Colonies. By a Cestificated Candidate, an Officer of Her Majesty's Civil Service. Crown 8vo, cloth, 2s. $6 d$.

4 THE MANSE GARDEN ; or, Plain Instructions in the Pleasant Culture of Fruit Trees, Flowers, Vegetables, and Sweet Herbs, for the Beauty and Profit of the Villa or Farm. By Nathaniel Paterson, D.D. Fifteenth Thousand. Crown 8vo, cloth, 2s.

This is a complete and practical guide for gardening in all depart ments. It is divided into three parts, viz., Forest and Fruit Trees, Vegetables and Sweet Herbs, and Flowers, on all of which such in. structions are given as can be easily carried out. This work also contains a select list of trees and flowers, a list of hardy, half hardy, and tender annuals, biennials, perennials, alphabctical list of particulas Alowers, monthly summary of gardening work in season, \&c. \&c. 


\section{Fames Blackwood E Co., Publishers,}

5. READINGS FOR YOUNG MEN, MERCHANTS, AND MEN OF BUSINESS, containing numerous Maxims, Truisms, and Articles on Probity and the Management of Business on Sound and Honourable Principles. Crown 8vo, cloth, Is. $6 d$.

6. COFLEBS IN SFARCH OF A COOK; with Divers Receipts and other Delectable Things relating to the Gastronomic Art. Crown 8vo, cloth, $2 s$.

Contents. - In Search of a Cook-On the Principse and Practice of Eating and Drinking-Income and Expenditure-Station in Life-Choice of Company-Conduct during Dinner-BreakfastsLuncheons and Suppers, and Bills of Fare and Receipts for Fiftythree Different Dinners, \&c.

7. GESENIUS' HEBREW GRAMMAR. Translated without Abridgment, by T. J. Conant, Professur of Hebrew in the Literary and Theological Institution at Hamilton, New York, with a Course of Exercises and a Hebrew Chrestomathy, by the Translator. A New Edition. Royal 8vo, cloth, 5s.

8. THE BROAD IINE DRAWING-BOOK, for the use of Young Beginners, containing nearly One Hundred Drawings of Objects. Sixth Thousand. Cloth, 2s. $6 d$.

Ditto, ditto, in Five Parts, each complete and sold separately, with covers printed in gold, $6 d$. each.

9. BLACKWOOD'S SHILLING ATLAS ; containing 13 Maps, corrected up to the Present Time. Coloured. Copious Index and handsome Wrapper printed in Colours, royal 4to, making it the most elegant and complete Atlas ever issued at the price. Is.

10. BLACKWOOD'S HAND ATLAS; containing 12 Maps, Coloured. Royal 8vo, is.

11. THE TEMPLES OF THE HEBREWS : Their Courts, Sanctuaries, Furniture, and Festivals. An Epitome of the Laws, Literature, Religion, and Sacred Antiquities of the Jewish Nation. By the Rev. T. Bannister, LL.D. Crown 8vo, 7s. $6 d$.

12. THE INFALLIBLE READY-RECKONER. With Complete Interest Tables, and much Useful Information. By W. COXHEAD. I8mo, cloth, Is.

13. THINGS YOU OUGHT TO KNOW CLEARLY EX. PLAINED, \&c. Crown 8vo, cloth, 2s. 6d. This work contains a vast amount of reliable information of a practical character, necessary to all engaged in mercantile pursuits, or, indeed, to all who mix in society; with a copious Index of Reference, by which any subject sought for may be easily found. 
Enibersal qLibrary of Standard Authors.

In royal $8 \mathrm{vo}$, cloth, Illustrated, 5s. each.

1. THE LIFE OF DR. SAMUEL JOHNSON, with his Correpondence and Conversations. By JAMES Boswell, Esq. Edited, with copious Notes and Biographical Illustrations, by EDWARD MaLONE. Unabridged edition. Illustrated.

2. THE COMPLETE WORKS OF OLIVER GOLDSMITE. Comprising his Letters, Essays, Plays, and Poems. With a Memoir by Professor SPALdING, and a fac-simile of a characteristic and humorous Letter of Goldsmith to a Friend, and other Illustrations.

3. THE COMPLETE WORKS OF ROBERT BURNS AND SIR WALTER SCOTT, with Portraits and a fac-simile of a Sonnet, and a characteristic Letter of Burns to Mr. Riddell, and other Illustrations.

4 THE COMPLETE POETICAL WORKS OF MILTON AND YOUNG, with Portrait and Illustrations.

5. THE COMPLETE POETICAL WORKS OF GRAY BEATTIE, BLAIR, COLLINS, THOMSON, ANL KIRIE WHITE, with a fac-simile of the MS. of Gray's Elegy, and other Illustrations.

6. MASTERPIEJES OF FICTION. By Eminent Authors, comprising Knickerbocker's New York, by WASHINGTON IRviNG; The Linwoods, by Miss SEDGwick; Elizabeth; or, The Exiles of Siberia; Paul and Virginia; The Indian Cottage; and Rasselas, by Dr. Jchnson. With Portrait of Washington Irving, and other Illustrations.

7. MASTERPIECES OF FOREIGN ITTERATURE, com. prising Schiller's Tragedies, Goethe's Faust : Translaced from the German by COLERIDGe and FILMORE; La Fontaine's Fables, and Saintine's Picciola ; or, The Prison Flower. Unabridged, with Portrait and other Illustrations.

8. ROBINSON CRUSOE, OF YORK, MARINER; with an Account of his Travels round Three Parts of the Glohe. with Eight Illustrations by Zwecker, engraved by Dalziel, and Eight Steel Illustrations by Stothard, engraved by Cinarles Heath.

9. ANECDOTES, LITERARY AND SCIENTIFIC, illustra. tive of the Characters, Habits, and Conversation of Men of Letters and Science. Edited by WILLIAM KEDDIE. Illustrated.

10. THE ARABIAN NIGHTS' FNTTERTAINMENTS. Translated from the Arabic. New edition, with 100 Illustrations. 


\section{Fames Blackwood \& Co., Publishers,}

\section{LIBRARYY OF FICTION AND HUMOUR.}

Small post $8 \mathrm{vo}$, Illustrated, 3 s. $6 d$. cloth, eacn.

ฐ. THE ADVENTURES OF MR. VERDANT GREEN, an Oxford Freshman. By CuthBert BEDE, B.A. With Hun dreds of Illustrations drawn by the Author. One Hundred and Seventh Thousand. Crown 8 vo.

"A college joke to cure the dumps."

2. HUMOUR, WIT, AND SATIRE. By CUTHBERT BEDE, B.A., Author of "Verdant Green." Crown 8vo.

3. THE WORLD IN LIGHT AND SHADE: Its Comicalities and Eccentricities. By Alfred W. Cole.

4 LEGENDS IN PROSE AND VERSE. Humorous, Serious, Sarcastic, Sentimental, and Supernatural. By ALFRed W. ColE. Illustrations by HARVEY.

5 MISS BROWN : A Romance; and other Tales. By R. B. BROUGH. Numerous Illustrations.

6. IITTLE MR. BOUNCER AND HIS FRIEND MR. VERDANT GREEN. By CuthBerT BeDE, B.A. With numezous Illustrations by the Author. 2s. $6 d$. 




\section{RETURN CIRCULATION DEPARTMENT 202 Main Library}

\section{OAN PERIOD I
HOME USE}

2
5

ALL BOOKS MAY BE RECALLED AFTER 7 DAYS

1-month loans may be renewed by calling 642-3405

3-month loans may be recharged by bringing books to Circulation Desk Renewals and recharges may be made 4 days prior to due date

\begin{tabular}{r|l|l|l}
\hline LIBRARY USE MA & 241978 \& & \\
\hline PEG, GI MAR 2 & 3 '78 & \\
\hline
\end{tabular}

FORM NO. DD 6, $40 \mathrm{~m} 10 ' 77$ UNIVERSITY OF CALIFORNIA, BERKELEY
BERKELEY, CA 94720 

